\title{
A GUIDE TO THE STUDY OF
}

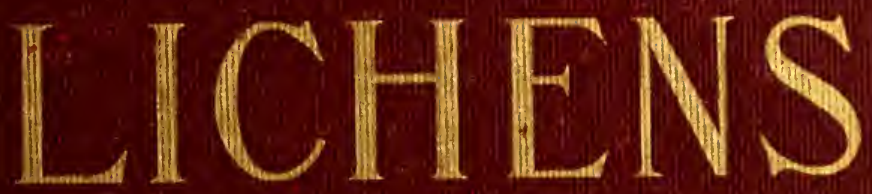

\section{SCHNEIDER}




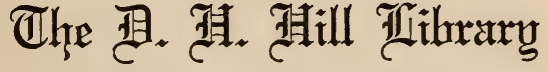

\author{
Zurth Taralina State \\ Crallege
}

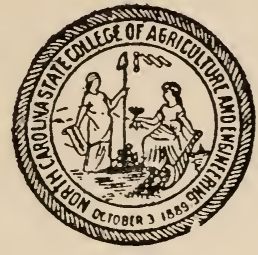

This book was presented

$$
\begin{gathered}
\text { L.A. Whitford } \\
\text { QK583 } \\
534
\end{gathered}
$$


This book is due on the date indicated below and is subject to an overdue fine as posted at the circulation desk.

EXCEPTION: Date due will be earlier if this item is RECALLED. 

Zur Erinnerung an Seine fflutter

Ber Berfagider 




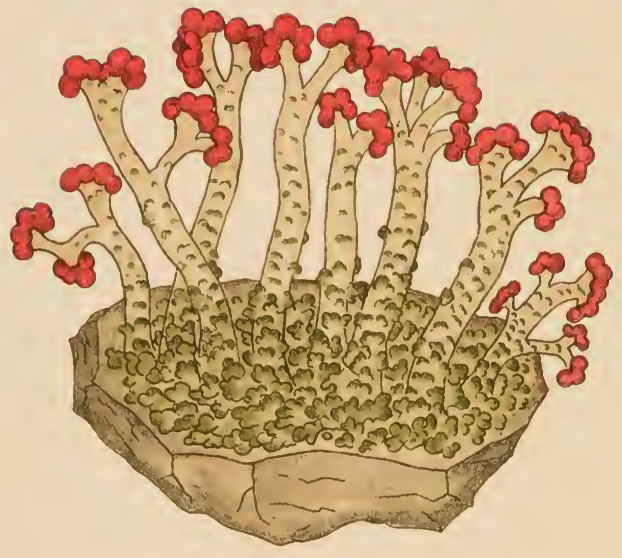

Cladonia cristatella 


\title{
A GUIDE TO THE STUDY
}

\author{
OF \\ LICHENS
}

BY

ALBERT SCHNEIDER, M. D., PH. D. Professor of Botany, Materia Medica and Pharmacognosy, California College of Pharmacy, San Francisco

With frontispiece in color

Twenty plates

SECOND EDITION

BOSTON

KNIGHT AND MILLET

1904 


\section{Copyright, 1898}

BY ALBERT SCHNEIDER

All rights reserved 


\section{CONTENTS.}

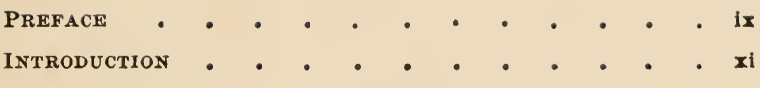

PART I.

The General Consideration of Lichens.

\section{SECTION I.}

The History of Lichenology • - • • . • . 1

I. From the EARLIEST TIME to WALLRoth AND MEYER (1825) • • . . . . . . . 2

II. From Wallroth and Meyer (1825) to the Close OF 1896 • • • • • • • • • •

SECTION II.

The Uses of Lichens . • . • . • . . 16

I. The Function of Lichens in Nature $\quad$ • $\quad 17$

II. The Econonic Value of Lichens • • • . 18

\section{SECTION III.}

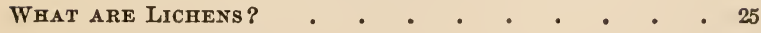

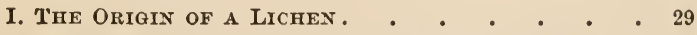

II. The Relation of the Lichexs to Alge aNd FUNGI • • • . . • • • • . 33

III. Lichens as Morphological Units . • . . 36 
SECTION IV.

The Morphology and Physiology of lichens . • . 39

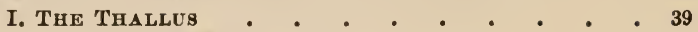

1. The Crustose Trpe • . . . . . 41

2. THE Foliose TYPE • • • • • • . . 42

3. THE FrUticose TYPE : • • • • • 44

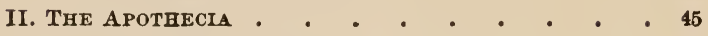

1. The Fungal Trpe • • • • • • . 46

2. The Thalline TyPe • • • • . . 47

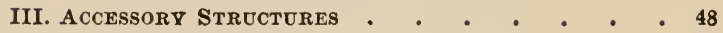

1. THE SOREdia . . . . . . . . 48

2. The CyPhelle . . . . . . . . . 49

3. The Cephalodi : . . . . . . 50

4. The Spermagonia . . . . . . . 50

SECTION V.

The Occurrence and Distribution of lichens . . 52

I. The Latitudinal and altitudival Distribution OF LICHENS • • • • • • • • • 52

SECTION VI.

Lichens ANd the Naturalist • • • • • • 56

I. The Collection of lichens • • • • • 56

II. The Study of Lichens

iII. The Preservation of Licheng . . . . . 65

\section{PART II.}

The Systematic Study of Lichens.

\section{SECTION I.}

Sygtems of Classification • • • • • • • • 73

SECTION II.

Keys to the StUdy of Lichexs . . . . . . 76

I. ARtificial Kry to the More Important Genera OCCURRING in THE UNited States • . . 77

II. Natural Key to the Families . . . . . 80 
CONTENTS.

vii

Description of Families, Genera and Species • • - 81

I. CAliciaceE • • • • • • • • • 81

II. Cladoniacele • • • • • • • • • 87

III. LecideAcex

IV. GRAPHIDACEE • •

V. Physciace瓜 • • • • • • • • . 132

Vi. Parmeliace

VII. VerrucariaceE

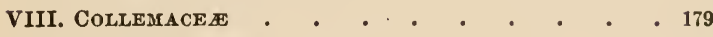

IX. Pannariacee • • • • • • • • 184

LiCHENS IMPERFECTI, OR FALSE LICHENS • • . . . 201

The Continental Range of the lichens Occurring in

the United States • • • • • • • . . 202

Alphabetical List of the Genera and Species Repre-

SENTED IN THE UNited States • • • • • • 204

GeNeral Index •

Plates • • • • • • • • • • • • . 235 



\section{PREFACE.}

THis little work is especially written and arranged for the use of amateurs in the study of lichens. By this it is not intended to convey the idea that the presentation of the subjectmatter is unscientific, incorrect or even out of date. The treatment of the subject is in harmony with the most recent results obtained by the leaders in the study of lichenology ; I have simply endeavored to present these results in such a way that they may be comprehended by all; in other words, an attempt has been made to popularize our present knowledge of lichens. It should, however, be kept clearly in mind that only the known facts or the completed work of science can be popularized. The advance-work of science, that is, the work whose aim it is to make new discoveries or to correct errors, can never be popularized; as soon as this is attempted it ceases to be advance-work. This statement is intended for those of the laity who are inclined to speak of scientific work as "nonsense" or as " a morbid taste for using big words." It is also intended for the serious consideration of those would-be scientists who are too anxious to "popularize science." It is further hoped that this statement will avoid possible erroneous conclusions as to the intended purpose of this book.

The existing nomenclature-difficulty does not concern or interest the average student of nature. In fact, the leading scientific specialists are themselves as yet wholly at sea as to when and where the controversy will end. For this reason the citation of authorities is omitted. The names given are well authenticated, so that those who have the desire and the 
opportunity may enter into the consideration of the synonymy and the nomenclature-controversy.

The lichens described are the more common forms occurring in the United States, those with which the collector is likely to come in contact. At the close is given a fairly complete list of the lichens found in the United States; this will prove helpful to those who wish to make exchanges. The artificial key is especially intended for the use of those who are not in possession of a compound microscope.

I take this opportunity to express my grateful obligations to Dr. N. L. Britton and Prof. Lucian M. Underwood, of Columbia University, who placed at my disposal the University collection of lichens. I am also greatly indebted to $\mathrm{my}$ wife, who has kindly given aid in correcting the manuscript and in reading the proof.

Chicago, January, 1898.

Albert Schneider. 


\section{PREFACE TO SECOND EDITION.}

The changes to the second edition are the addition of six full-page half-tone illustrations of typical representatives of the three great subdivisions of the lichens; namely, the crustose, foliose, and fruticose. These will be of great value to beginners in the study of this remarkable group of plants.

Since the issue of the first edition no important discoveries have been made in lichenology, hence no changes have become necessary in the text.

I take this opportunity to express my obligations to Miss Alice Eastwood, of the California Academy of Science, and R. S. Gray, Attorney, San Francisco, for the loan of material, as well as for assistance in collecting specimens.

Albert Schneider.

San Frascisco, August, 1903. 



\section{INTRODUCTION.}

Lichens form a group of plants which has been not so much overlooked and neglected as misunderstood and abused. The term lichen is rather unfamiliar, but not so the term "moss," by which the plants here referred to are quite generally known to layman as well as to poet. And, indeed, the term moss is justifiable if we trace it to its Scandinavian origin. All comparatively small thalloid cryptogams - that is, flattened, stemless and flowerless plants were known as moss (mosi, mossa, moos, mus). The term, therefore, included lichens, liverworts and mosses proper. But from the present standpoint of science lichens are not mosses, as will be made clear later; lichens are an independent group of plants having no genetic relationship to mosses.

Nor must it be supposed for a moment that lichens are uninteresting and insignificant. With the one exception of marine algæ, no plants present such truly beautiful and artistic features to the amateur in naturestudy. No group of plants is so easily obtainable or 
lends itself so readily to the critical examination of the student and to the decorative fancies of the artisan. Neither is it necessary to enter a plea for the kindly consideration of these plants because they have been neglected and abused. Lichens do not require pity: they are more than competent to hold their own in the great struggle for existence. Indeed, many of the much petted and much praised higher plants owe their very existence to the lichens. It is true, lichens cannot boast of an exalted origin or noble ancestry, but they have gradually advanced in a beneficent life-work, so that at present their lowly origin is wholly lost sight of.

Let us, therefore, obtain a better insight into these plants, so that we may judge them more fairly and assign them to their proper position in the world of life, and duly credit them with the grand work they are performing. Let us hope that no one, on seeing a lichen, will say, "Oh! that is a moss," or, "It's nothing; it just grows on trees." A lichen is as deserving of recognition as the oak upon which it grows or the reindeer whose life it sustains. 
PART I GENERAL CONSIDERATION OF LICHENS 



\section{SECTION I.}

\section{THE HISTORY OF LICHENOLOGY.}

The history of lichenology is a remarkable one. It indicates that this special science has progressed in a devious and interrupted course. It is only within a few years that scientists have arrived at any comparative certainty as to the true nature of these plants. Wonderfully absurd opinions were entertained as to their origin and economic uses. For these reasons a brief historical review is not only interesting but highly important.

Historically, time is usually divided into periods or epochs; such divisions are, however, more or less arbitrary and depend somewhat upon the judgment of the author. The establishment of periods very greatly simplifies the presentation of an historical review. It must, however, not be supposed that the greater the number of epochs or periods the simpler the history; generally the contrary is true.

The most exhaustive history of lichenology is that by Krempelhuber, published in the year 1867. This author divides the history of our science into six periods, as follows : 1, from the earliest times (Theophrastus) to Tournefort (1694) ; 2, from Tournefort to Micheli (1729); 3, from Micheli to Weber (1779); 4, from Weber to Acharius (1810); 5, from Acha. 
rius to De Notaris (1845); 6, from De Notaris to 1867. In my "Text-book of General Lichenology" I have retained Krempelhuber's limitations of the first three periods; the others have been changed, and the review has been completed to the beginning of 1897. As thus modified, the fourth period is from Weber to Wallroth and Meyer (1825), the fifth from Wallroth and Meyer to Schwendener (1868), the sixth from Schwendener to Reinke (1894), and the seventh beginning with Reinke. The reasons for the changes will become evident upon the consideration of the historical review as here given.

For the purposes of a very brief review it was thought best to recognize two grand periods. Only a few of the more important workers in lichenology will be mentioned. At the present time the publications on lichens number many thousands; to collect and digest these is the work of years. The beginner will, however, feel somewhat relieved to learn that of the thousands of publications on lichens only a comparatively few are of any intrinsic value or add to our knowledge of the subject.

I. FROM THE EARLIEST TIME TO WALLROTH AND MEYER (1825).

This may be characterized as the period in which no real scientific study was made of lichens. The botanical systematists of the time devoted their attention to the higher plants, especially those of real or imaginary economic value. The lower plants were quite generally neglected, lichens in particular. 
In a work ascribed to Solomon a large number of higher plants are mentioned but not a single cryptogam. The reason why lichens should be especially neglected becomes apparent when we consider that with few exceptions they are not striking in size, color or form, nor do they seem to possess any marked useful or harmful properties.

No historian has been able to give any reliable information regarding the earliest knowledge and uses of lichens. Evernia furfuracea is said to have been found with Egyptian mummies, where it was doubtless used as packing material. There is no reason why this lichen as well as others (species of Usnea in particular) should not have been used for similar purposes by the ancient peoples of northern Africa, Arabia, Italy and other countries in which these plants occur very plentifully. Theophrastus (371-286 B. C.), a pupil of Aristotle, was perhaps the first writer who left any record of lichens. From his rather imperfect descriptions we are led to believe that he was more or less familiar with Usnea barbata and Rocella tinctoria. The former no doubt attracted attention because of its beard-like growth upon trees, oaks in particular. The latter has been long known on account of its coloring properties. These two lichens were also mentioned in the works of Dioscorides and Plinius. With these exceptions, lichens received no attention until the sixteenth century, when science, art and literature awoke from the paralytic state into which it had sunk since the first century. About the middle of the sixteenth century, Ruellius, Gessner, 
Cæsalpinus and Camerarius, who were among the earliest commentators on the writings of 'Theophrastus, Dioscorides and Plinius, did little more than to reiterate what was already known of lichens. At the close of this century about twenty-eight species or forms of lichens were described. The Scotch botanist Morison (1683) described fifty-six lichens, some of which were quite well figured.

The Italian botanists were the beginners in the study of the structure and growth of lichens. Malphigi (1686) was the first to call attention to the soredia, which he considered to be the true seeds of lichens, since he had observed that new plants were developed from them. Porta (1591) gave some very crude explanations of the origin and growth of lichens, which indicated that he had some fairly correct ideas of the nature of these plants, while Morison, who seemed to have been an accurate observer otherwise, expressed it as his opinion that lichens were excrementitious matter produced by the soil, rocks and trees.

At the close of the seventeenth century about 125 lichens were known and described. Especially important was the work of Tournefort (1694-1719). This author called special attention to the apothecia and some of the spores. His descriptions of the histological characters were of necessity crude, owing to the imperfections of the simple microscopes, the compound microscope being as yet unknown.

The systematic study of lichens really began with the Florentine botanist Micheli (1729). Heretofore all lichens had been placed in the one group "lichen," 
though some considered them as "mosses" or "fungoid" mosses. Micheli proceeded to arrange all the known species or forms into thirty-eight orders based upon the general macroscopical characters and the consistency of the thallus. He illustrated the orders and also studied the apothecia and the spores. Twelve years later John Dillen issued his noteworthy " Historia Muscorum," in which the lichens are classified as mosses. His work is well illustrated, and in many respects the system of classification is superior to that of Micheli.

After the above botanists others exercised their ingenuity in establishing systems of lichens. Some authors classified them with mosses, while others placed them with fungi. The various groups were quite universally based upon the external appearance and nature of the thallus. Linné, "the immortal Swede" (1753), combined all lichens in one group in agreement with Tournefort. He, however, established sub-groups based upon the characters of the thallus as well as upon those of the apothecia.

It will be remembered that at first there was a tendency to classify lichens as a distinct group of plants ; later to consider them as mosses or even as fungi. This doubt and uncertainty continued to grow until the close of the seventeenth century, when the confusion reached its highest point. They were not only classed as mosses and fungi, but also as algæe, sponges, liverworts, etc. This difference of opinions was due to the fact that the knowledge of the lower plants, of lichens in particular, was very imperfect. Linné, who never pretended to be a friend of the cryptogams, des- 
ignated lichens as "rustici pauperrimi," which might well be translated as "the poor trash" of vegetation. This lack of interest in the lower organisms was quite universal and explains why lichens were neglected, particularly the really insignificant crustose forms. As the result of the combined efforts of the various lichenographers some 500 species or forms of lichens were known at the close of the eighteenth century.

The first investigator who made an attempt to study the morphology and physiology of lichens was $J$. Hedwig (1784). Though his conclusions were in the main wrong, yet his investigations served as a stimulus and an inducement to further study. This author, was the first to make a special study of the spermagonia. He also studied the spores and soredia. He believed that the spermagonia were the first to develop and that the apothecia and soredia developed upon these subsequently. Furthermore, the spermagonia were looked upon as the male reproductive organs, the soredia as the fertilizing elements and the apothecia with the spores as the female organs. A. P. De Candolle (1798) made some interesting experiments as to the manner in which the different lichens take up their food-supply. During the same year Acharius, who is often spoken of as the "father of lichenology," issued his "Prod. Lich. Suec.," in which he expressed great uncertainty in regard to the manner of fertilization and the nature of the reproductive organs. $\mathrm{He}$ even questioned whether lichens were plants and expressed a desire to classify them as polyps. Georgi (1779) made the 
first chemical studies of lichens. He found that they contain such organic substances as oil, resin and mucus and various inorganic salts. In the year 1810 Acharius issued his "Lichenographia Universalis," which was the most voluminous and complete work on lichens yet issued. It is simply a manual of lichens with rather imperfect descriptions of species. His illustrations, particularly those of the spores, are poor. One would expect better work from so eminent a botanist. He did not make use of the spore-characters in his system. Other eminent botanists, as Lamarck, De Candolle, Fries, Fée and Eschweiler, established systems of classification; all of which were artificial and inadequate.

Some of the leading botanists of the time believed that lichens were related to fungi as well as to the algæ. Accordingly Agardh, Voigt, Endlicher, Lindley, Reichenbach and others considered lichens as a distinct class to be placed between the algæ and fungi. Sprengel and Oken also considered them as a distinct class but placed them between liverworts and algæ; De Candolle placed them between liverworts and fungi. Many other botanists still considered lichens as a subordinate group belonging to various natural classes, as alga, fungi, mosses, etc.

At the beginning of the nineteenth century the belief in spontaneous generation was quite general. Sprengel and others were convinced that, under favorable circumstances, lichens were evolved from decaying substances, or the decomposition of water. Agardh (1820), the eminent algologist, stated that he had 
observed the development of the lichen Collema limosum from the alga Nostoc muscorum var. lichenoides. A general belief of that time was that the so-called "primal substance," or " green substance of Priestley" (perhaps Protococcus vulgaris or other unicellular alga) could develop into algæ, lichens, mosses and other lower plants. Nees von Esenback was wont to guide his pupils to the old castle at Pottenstein in order to demonstrate ad oculos how the green substance of Priestley occurring on the stone walls could develop into a lichen, while if placed in water it would develop into an alga.

Thus we see that during this entire period, which extended over two thousand years, scarcely anything more was done than to name and roughly describe between 500 and 600 species of lichens. The heated discussion, the wrangling and the uncertainty in regard to the origin and position of lichens was simply evidence of ignorance and not a sign of profound knowledge of the subject. Scarcely a ray of scientific light had as yet penetrated the Stygean darkness in which these highly interesting plants were enwrapped. It simply shows that scientific progress, like all progress, is slow and its devious path is strewn with thorns and stumbling-blocks.

II. FROM WALLROTH AND MEYER (1825) TO THE CLOSE OF 1896.

This might be designated as the period of scientific lichenology. Leading botanists now began to study the life-history, the morphology, histology and physi- 
ology of lichens. It must, of course, be emphasized that this was heretofore practically impossible owing to the imperfections of the microscope. 'The compound microscope was introduced at the beginning of the nineteenth century, but, like all innovations, was comparatively imperfect and was looked upon with disfavor by many scientists who should have known better; some even going so far as to openly assert that the compound microscope would never excel the most perfect simple leuses.

The impetus to the scientific study of lichens was given by two German scientists, Wallroth and Meyer, who, peculiarly enough, began their work independently but covered much the same ground and publisherl their results in the same year (1825). Both made a special study of the morphology, growth and metamorphosis of the lichen-thallus. Wallroth's style is very involved. Each sentence contains a long series of parenthetical clauses often occupying nearly an octavo page. His terminology is also peculiar and requires a special study. On one question the two eminent writers were diametrically opposed; while Meyer believed in the spontaneous generation of lichens, Wallroth did not, it being his opinion that they developed from gonidia and spores as well as by vegetative propagation. Wallroth gave a very detailed description of the structure and function of the gonidia, soredia and apothecia as well as of the thallus. Although this author did most excellent work there is no evidence to show that he made use of the compound microscope; in some instances he did not even use the 
simple lens. Meyer's studies were perhaps even more comprehensive than those of Wallroth. He entered into a careful investigation of the structure and metamorphosis of the thallus and apothecia, the gonidia and spores, the growth and nutrition of lichens and their relation to the substratum.

Stitzenberger (1862) was perhaps the first to emphasize the importance of the spore-characters in the classification of lichens. According to this author it is principally the generic distinctions which are to be based upon the spore-characters. Lichens with colored and colorless spores are not to be included in the same genus, nor those whose spores differ in the number or direction of the septa, etc. According to the systematist Körber (1865) 1,051 species of lichens had been collected in Germany and Switzerland. Of this number Körber described 272 species as new. Massalonga (1853) made a careful study of the structure of crustose lichens and concluded that the sporecharacters as well as the form and structure of the apothecia and thallus should be considered in the establishment of genera. Fries (1861) recognized the importance of the spore-characters but considered the form of the spermatia as of nearly equal significance; in this he was seconded by other authors. The English lichenologist Mudd (1861) rightly objected to this procedure because nothing was known of the function of spermagonia and also because the spermatia were not sufficiently varied in form to be of marked importance in classification. Nylander (1858) more than any other investigator has emphasized the importance 
of the spermatial characters in classification. This author, however, did excellent work in the morphology of lichens. He was also the first to point out the double affinity of lichens; on the one hand they showed a close resemblance to fungi, on the other to algæ. He published a list of all the known lichens, which included 1,348 species, 298 of which were described as new. Nægeli (1847) classified lichens as algæ under the group Lichenaceæ and placed them between the Confervaceæ and Exococcaceæ. Itzigsohn's (1854) opinions underwent great change as regards the spermagonia. At first he was inclined to look upon them as parasitic fungi, abnormal spore-organs, apothecia or even parasitic lichens. Subsequently he stated that they were the antheridia analogous to those of mosses, of which the spermatia were the spermatozoa. Somewhat later he was inclined to believe that the gonidia were the female organs and the spermatia the male organs. Species of the algx Pleurococcus, Ulothrix, and others, were supposed to be free unfertilized gonidia. Tulasne (1852) gave us a very complete and scientific memoir on the histology of lichens. Lindsay (1856) wrote a most excellent popular treatise on British lichens. A little later Schwendener (1858-1868) began his morphological studies of lichens which were even more complete than those of Tulasne. In 1868 Schwendener came to the conclusion that the so-called gonidia of lichens were nothing more nor less than simple-celled algæ and that the spore-bearing portion of the lichen was a fungus living parasitically upon the alga. 
This in a nutshell is the great discovery of Schwendener and which has revolutionized the study of lichens. Reinke (1873) pointed out that the relation of fungus and alga as it occurs in the lichen was not ordinary parasitism ; that it indicated a relationship in which both organisms were benefited. This relationship he designated consortism. De Bary (1879) described this phenomenon more fully and designated it symbiosis, that is a "living together" for mutual benefit.

As a result of Schwendener's investigations lichens were considered as fungi and were classified as such. There was, however, great opposition to this method of classification, especially on the part of the pure systematists. In $1874 \mathrm{Stahl}$ made a special study of the spermagonia which led him to conclude that the spermatia were the male fertilizing elements. Sturgis (1890), an American scientist, seconded the conclusions of Stahl. To Tuckerman we owe most of our systematic knowledge of the American lichens. His descriptions of species, carefully given, makes his work the first that could be utilized by those of ordinary capabilities. The style of Leighton's manual of British lichens is peculiar; the descriptions of species are given in a peculiar mixture of English and Latin which made it necessary for him to append an extensive glossary of terms. Crombie (1895), also a British lichenologist, retains the same style. Hué (1892) has published a list of lichens from which it may be concluded that about four thousand species are known at the present time. 
Within comparatively recent years there have been numerous investigators who have made a special study of the relationship of fungus and alga as they occur in a lichen. We cannot cite authors nor enter into any discussion of the results obtained.

The general conclusions may be summarized as follows :

1. Certain algæ, mostly of the simpler Chlorophyceæ and Cyanophyceæ have entered into an intimate biological relationship with certain fungi mostly derived from the Ascomycetes (sac-fungi).

2. A lichen is represented by a fungal portion and an algal portion. The two parts enter into a symbiotic relationship which is of such a nature that both are very materially benefited. The two organisms are complementary to each other, one supplies what the other lacks.

3. The fungal portion cannot exist independently, while the algal portion can.

4. The algal types are fairly well known. They are (1) Cystococcus humicola which occurs in the majority of lichens; (2) Pleurococcus vulgaris; (3) Exococcus ; (4) Glcocapsa; (5) Chroococcus; (6) Nostoc; (7) Stigonema; (8) Chroolepus; (9) Confervacea.

Bornet, Baranetzky, Famintzin and Woronin are among those whose efforts have aided in giving us a more exact knowledge of lichens. Jumelle (1892) is perhaps the first who has entered into a careful study of the carbon-assimilating function of lichens. Reinke (1894-1896) after considerable study came to the 
conclusion that lichens should be considered as a distinct class. According to this author a lichen is as much a morphological unit as a fern or an oak. A lichen is not a fungus parasitic upon algæ. He has shown that the existence of the lichen is dependent upon the relationship of the fungal portion and the algal portion. Separating the two destroys the lichen. Lindau (1895) objects to Reinke's views and agrees with Schwendener. Darbishire (1897) is a strong supporter of Reinke. He has also made a careful study of the soredia (soralia) as they occur in the Pertusarias. As for myself I favor Reinke's view as will be explained more fully later.

Thus concluaing the historical review with the beginning of the year 1897, we find the status of our knowledge of lichens somewhat as follows :

1. Schwendener's theory of the dual nature of lichens is quite universally accepted as correct. That is, a lichen consists of a fungal and an algal portion.

2. Reinke's theory of the autonomy of lichens is beginning to receive general recognition. According to this view a lichen is not a fungus parasitic upon algæ. The mutual interdependence of the fungus and alga is so great that in many instances neither can exist alone.

3. Lichens doubtless form a distinct class equal in systematic importance to mosses, fungi, liverworts, etc.

From this historical review we learn that lichenology has had a very checkered career and that the ad- 
vance has been very slow. Most of the real scientific progress has been made within the past thirty or forty years. Considerable work is yet to be done before our knowledge of lichens arrives at any considerable degree of accuracy. 


\section{SECTION II.}

THE USES OF LICHENS.

Whatever exists, exists for a purpose. If it exists for a purpose, it serves some use in the economy of nature. In many instances this purpose or use is not apparent because not understood. If a thing is decried as useless it simply indicates that it is not sufficiently understood. Nature produces no useless things. From the standpoint of the optimist, all things, inclusive of those designated as bad or harmful, work ultimate good.

As indicated in the historical review, lichens have been unfairly judged. They have been looked upon as vegetable monstrosities. One comparatively recent author considered them as mosses which had been checked in their development. Linné looked upon them as the "beggarly among plants." Others considered them as waste products of earth, rocks and trees. They were quite generally considered as altogether insignificant and useless, if not harmful. Even poets were inclined to speak of them disparagingly. The great part that lichens play in the economy of nature was wholly overlooked. There were, however, a few who ascribed to these plants medicinal properties which they do not possess. As an article of diet and 
in the dyeing industry, lichens found a useful place early in the history of civilization.

\section{THE FUNCTION OF LICHENS IN NATURE.}

The task that lichens perform in the economy of nature is indeed Herculean and out of all proportion to their size. They are the hardy pioneers preparing the way for the advance of the less hardy vegetation. Their hardiness is shown by their ability to resist greater extremes of temperature than any other plants, or even animals. They have gainer the reputation of being able to live on nothing but air and sunlight. This is, perhaps, scarcely true, but it is a fact that they require less organic food than other plants. In general, lichens are to be compared to green chlorophyllbearing plants, since they take up carbon dioxide from the air and give off oxygen. They thus add their mite toward keeping the air in a suitable condition for the respiration of higher animals.

The most important function that lichens perform in nature is the preparation of soil. Many of the crustose lichens occur upon the hardest rock, to which they are closely attached, forming dirty grayish or greenish patches. Erroneous opinions as to the manner in which lichens disintegrate the rock are very prevalent. A recent author puts it as follows: "One peculiarity of some lichens is the power they have to burrow in to the hardest rocks, even flint and granite, thus making for themselves homes (faveoli)." Other authors make similar statements. Such statements are wholly unscientific, hence untrue. No lichen has 
the power to burrow into rock of any kind, not even into vegetable tissue; such a thing is physically impossible. Nevertheless lichens disintegrate the hardest rock, and it is done approximately in the following manner: Rock-lichens, as well as others, secrete various acids which have a solvent action upon the less resisting rock-particles. As a result the rock crumbles and the hyphæ of the lichen extend between the loosened particles. The lichen may thus be almost entirely imbedded in the disintegrated rock-material; the whole mass being held together and to the unaffected rock . the gelatinous hyphæ. In time the lichen dies, decays and becomes mingled with the rock-particles, forming a suitable substratum for the higher lichens, such as the large foliose and fruticose forms. In turn these also decay and aid in forming a suitable soil for mosses, ferns and even higher plants ; that is, death and decay gives rise to new life. Throughout nature we find that those living give up their lives that others may live. Lichens are the most altruistic of all living organisms, since they live wholly for the good of others. Nearly all other plants require at least a substratum resulting from the death and decay of others. Many lichens live upon wholly inorganic substrata and exert their entire life-energy for the benefit of other living creatures.

\section{THE ECONOMIC VALUE OF LICHENS.}

We shall here refer to some of the more important uses to which lichens have been put. Other special uses will be referred to in the discussion of the species. 
All lichens contain a larger or smaller percentage of a starch-like substance known as lichenin, or lichenstarch. It has the same chemical composition as starch $\left(\mathrm{C}_{6} \mathrm{H}_{10} \mathrm{O}_{5}\right)$ but differs in that it usually does not give the blue reaction with iodine. It is to this substance that lichens owe their nutritive properties. From time immemorial the poor of various countries have made use of lichens as an article of diet, just when it was first so used is impossible to determine accurately. Excavations of prehistoric cave-dwellings (Germany) have revealed the presence of lichens (Cladonia rangiferina) among the bones of various animals, which would indicate that man of that early period had already made some economic use of lichens. The "miraculously" supplied manna of the Israelites (Exodus xvi, 14, 15) in the wilderness is supposed to have been a species of Lecanora (L. esculenta). This lichen occurs very plentifully in the mountainous districts of Tartary, Algeria and other parts of northern Africa. The plant occurs in small nodular masses, grows and spreads quite rapidly under favorable conditions. These lichens are only loosely attached to the substratum, so that they are readily torn loose and carried by the wind into the valleys below, where the ignorant and oftentimes hungry peasants suppose them to be bread rained from heaven. Travellers in the above countries have reported several noteworthy and extensive "rains of manna." The Kirghiz Tartars eat this lichen under the name of "earth-bread."

Iceland moss (Cetruria islandica) has been most extensively used as an article of diet because it con. 
tains a high percentage of lichenin. The peasantry of Iceland, Norway and Sweden powder it and mix it with the flour of various cereals and mashed potatoes, from which an "uncommonly palatable and healthful bread is prepared." A diet of this lichen was also said to prevent a peculiar form of scurvy, or elephantiasis, known as "Iceland scurvy," quite prevalent in Iceland and the Scandinavian peninsula.

Rock-tripe, a species of Umbilicaria, has often been the means of saving the lives of arctic explorers, notably the members of the Franklin expedition, also of trappers and hunters in Canada and Alaska. Some of the companions of Franklin found, to their sorrow, that a diet of this lichen produced a severe intestinal inflammation, no doubt due to the bitter principle it contains. This bitter principle is more or less present in all lichens, and is said to be removed by repeated washings or soaking in a solution of potash or some other alkali. In the northern countries of Europe a common method of preparing lichens for the table was to make a decoction in milk after they had been repeatedly washed in water. It is, however, very difficult to remove the objectionable bitter principle entirely, and for this reason lichens were never extensively used as an article of diet, excepting in cases of famine. The peasants of Norway and Sweden collect large quantities of various lichens as fodder for their cattle. Every one is familiar with reindeer-moss (Cladonia rangiferina) as a food-supply for the reindeer of Lapland.

Perhaps the most important and oldest use to which lichens had been put was in the dyeing industry. 
Theophrastus and Dioscorides described Rocella tinctoria as a "marine fungus growing upon rock, possessing coloring properties," from which it is concluded that dye made from the lichen was known before that time. It was in use before the time of Pliny. The "blue and purple" of the Old Testament (Ezekiel, xxvii, 7) no doubt refers to the coloring substance obtained from this lichen.

After the fall of the Roman empire the knowledge of the use of the dye obtained from Rocella seems to have been lost. About the year 1300, Federigo, a Florentine of German parentage, accidentally rediscovered the method of preparing and using this dye. $\mathrm{He}$ is said to have achieved such great success in his commercial transactions therewith that in time he became the head of a distinguished family, the Oricellarii, who were later known as the Rucellarii and Rucellai. From these names are derived orseille, the name given to the coloring substance, and Rocella, the group of lichens from which orseille was prepared. For more than a century Italy supplied the market with orseille derived mainly from lichens collected on the islands of the Mediterranean. After the discovery of the Canary Islands, in 1402, much of the dye was obtained from those islands; still later from the Cape Verde Islands, as well as from other islands and countries. Later it was found that species of Lecanora, Pertusaria, Umbilicaria, Gyrophora, etc., vielded excellent dyes.

The method of preparing the dye is quite complicated and many complex chemical reactions are in- 
volved. In general, it may be stated that the lichen is pulverized and macerated for some time in some alkaline solution, as lye, or ammonia, whereby a beautiful purple color is obtained. Orchill, cudbear and litmus are different names for the same coloring substance. The first is the English preparation which occurs as a rich purple paste; the second is the Scotch preparation which is found in the market as a carmine or crimson powder; the third is the Dutch preparation and occurs in small oblong cakes of an indigoblue color. Litmus, as well as the other dyes, has the peculiarity of turning red in the presence of an acid and blue in the presence of an alkali. The litmus-paper so extensively used in chemical laboratories is ordinary filter paper dipped into a neutral solution of litmus.

Later orseille was used principally in dyeing silken goods. France more than any other country improved upon the methods of extracting the dye, as well as in applying it. As to the value of the dye it may be stated that about the middle of this century the "orchella-weed" sold at prices ranging from $\$ 100$ to more than $\$ 1,000$ per ton. The chief objection to the use of orseille is its instability, being subject to fading; furthermore, the process of dyeing is very apt to injure the cloth. Orseille is also used by artists as a pigment.

In Sweden Evernia vulpina is known as "Ulfmossa" (Wolf's moss), because it was said to have been used in poisoning wolves. According to Virey, the lichen is powdered and mixed with powdered glass, which is sprinkled upon meat exposed for wolves 
to feed upon. The wolves eat of this and die. According to Fabricius, nux vomica, and not powdered glass, was mixed with the lichen, which seems more probable. The dog-lichen (Peltigera canina) formed the basis of the noted "anti-hydrophobia powder" (pulvis antilyssus or pulvis contra rabiem) of the London Pharmacopœa (1721 to 1788). In the history of the Royal Society (London) it is recorded that several mad dogs belonging to the Duke of York were cured by this powder. Dr. Mead recomments the following treatment in a case of hydrophobia: "The patient is bled and ordered to take a dose of the powder (equal parts of the lichen and red pepper powdered) in warm milk for four consecutive mornings; thereafter he must take a cold bath every morning for a month and for two weeks subsequently three times a week." Dioscorides recommended Usnea barbata, known as the "beard moss," in certain diseases peculiar to women. Later it was very highly prized as a remedy for whooping-cough, epilepsy and as an anodyne. It also formed the main ingredient in powders recommended to promote the growth of hair. The yellow Physcia parietina was considered a specific in jaundice and was also used as a substitute for quinine. During the Napoleonic wars (1809-1815) fevers of all kinds raged in the military hospitals. Quinine, which was then the popular remedy for fever, became very scarce, on account of its rapid consumption and because of the commercial blockade which prevented its importation. The Austrian government therefore offered a prize of five hundred ducats for the discovery of a cheap 
and readily accessible substitute for quinine. Sanders, who secured the prize in part, proposed Physcia parietina as such a substitute. It proved, however, very unsatisfactory and its use was soon entirely discontinued by physicians.

From their alleged aptitude for imbibing and retaining odors and scents the powder of several fruticose lichens formed the basis of certain perfumes which were celebrated in the seventeenth century. The astringency of some species rendered them serviceable in tanning and even in brewing; the beer of a certain Siberian monastery, celebrated for its peculiar bitterness, owed this to Sticta pulmonaria. French and Scandinavian chemists employed Cetraria islandica and Cladonia rangiferina in the manufacture of alcohol. The method of procedure is essentially as follows: The lichens are treated with sulphuric or hydrochloric acid, which transforms the lichenin into glucose; this, being allowed to ferment, produces alcohol. Two pounds of the lichen furnishes about one pint of alcohol.

Attempts were also made to use lichens in the manufacture of paper but the results were very unsatisfactory, as these plants contain no tenacious fibres. They are still very extensively used in the decorative work of the taxidermist. Some species furnish a gum used in the manufacture of pasteboard.

In conclusion, it may be stated that the medicinal virtues of lichens are largely imaginary. The only officinal lichen to-day is Cetraria islandica, a decoction of which is recommended as a tonic for convalescents. 


\section{SECTION III.}

\section{WHAT ARE LICHENS?}

Is order to comprehend the true nature of lichens it is necessary to have a correct idea of their origin; we must have some conception of their position in nature, of their relation to other plants. Lichens originated in a manner wholly different from any other group of plants. Their history of development is most remarkable, and stands without a parallel in the world of living things. In order to make clear this wonderful origin and development it is necessary to enter into a brief consideration of fungi and the lower algæ. The impatient reader may ask, "What do fungi and algæ have to do with lichens?" He will soon learn that without these plants lichens could not have come into existence. We shall begin the discussion with algæ.

Every one is more or less familiar with the lower algæ; they occur plentifully upon tree-trunks, fences, upon flower-pots, walls and woodwork of greenhouses, etc.; they form the green scum on ponds and brooks, in watering-troughs, in fact, in nearly all moist places and in water exposed to sunlight and warmth. These plants are very small, the individual plant is, in fact, too small to be seen by the naked eye. Several hundred must become associated to form a minute green speck. 
If we scrape off a small fragment of the green coating of a tree or flower-pot and examine it under a microscope we find that it consists of numerous minute globules, perhaps five-thousandths of an inch in diameter. Each globule is an individual alga and is nothing more or less than a single cell. Not all of the lower algæ are single-celled however ; many consist of chains or filaments of cells or even of a highly complex structure. The algæ with which we are concerned are either single-celled or form simple or branching chains of cells. Their structure will be more fully described later.

Algæ contain a green substance known as chlorophyll. It is this substance which enables the organism to assimilate inorganic food; a function peculiar to all chlorophyll-bearing plants and which distinguishes them from animals and parasitic plants. Animals and fungi can only assimilate the food-substances directly or indirectly prepared by the chlorophyll-bearing plants. This brief reference to the algæ will suffice for the present. The facts to be distinctly kept in mind are that algæ contain chlorophyll and have the power of assimilating inorganic food-substances under the influence of sunlight. Now as to the fungi.

Every one has seen toadstools, puff-balls, mould on bread and other organic substances kept in moist and rather dark places, rust on wheat and other cereals, smut on corn, etc.; all of these are fungi. Every one has heard of bacteria and is more or less familiar with the rôle they play in disease; some have no doubt heard of the importance of bacteria in the manufacture 
of cheese, in tanning, and in the making of butter; all are familiar with processes of fermentation. These bacteria, whether indifferent, harmful or beneficial, and the producers of fermentation, belong to the fungi.

It is also generally kuown that fungi are either saprophytic or parasitic, that is, they require organic food obtained from dead or living organisms. In this they differ markedly from chlorophyll-bearing plints, as already indicated. Scientists have however determined that fungi were originally chlorophyll-bearing and hence able to assimilate inorganic food; in other words, fungi are algæ which have lost their chlorophyll and the functions pertaining thereto. How dicl they come to lose their chlorophyll? The history of this change is, perhaps, something as follows: Many ages ago certain of the alga accidentally came in contact with higher plants, from which they absorbed some of the more soluble food-substances. The association reduced the amount of work to be done by the chlorophyll of the parasite; as the association continued the morphological and physiological changes in the alga tended toward a more and more marked parasitism. Every one is familiar with the fact that inactivity of an organ causes it to become dwarfed and more or less functionless. Chlorophyll became extinct in these parasitic algæ simply because it was functionless : all of the organic food was prepared and supplied by the host. This cliange was by no means sudden; it required many ages to produce the change from bright green alga to colorless fungus, or, in other words, to 
convert the independent chlorophyll-bearing organism into a dependent chlorophylless organism.

The above is in brief the history of the origin and development of all vegetable parasites. Even now we can find all gradations between parasitic states just making a beginning, as, for example, some species of Nostoc and Protococcus, and the most highly developed parasitism, as, for example, most of the fungi. Saprophytes differ from parasites only in that the originally green, hence chlorophyll-bearing plants, became adapted to live upon dead organic matter rather than living organisms. It must also be kept in mind, that as parasitism and saprophytism progressed the resulting fungi underwent structural changes; so that it is in many instances practically impossible to recognize the resemblance to any living forms of algæ. Scientists are, however, quite generally agreed that fungi are derived from algæ.

As a rule, fungi reproduce their kind by means of very minute microscopic bodies known as spores. All of the higher fungi may be divided into two groups according to the manner in which the spores are formed; in the one group they are formed on the ends of specialized hyphæ, known as basidia, in the other group they are formed within specialized hyphæ, known as spore-sacs (Asci). The latter are therefore commonly known as sao-fungi. We have to deal with the sacfungi (Ascomyctes) only. There is, however, one Southern lichen (Cor $a$ ) which forms basidio-spores. It is the only exception occurring in the United States and is, furthermore, of rare occurrence. Keeping, there- 
fore, in mind, that in the discussion of lichens we are concerned with certain genera of the lower algæ belonging to the Chlorophyceæ and the Cyonophyceæ, and a division of the higher fungi known as sac-fungi (Ascomycetes), we shall now briefly explain the phylogenetic history of a lichen. The origin of one lichen is in all essential respects similar to that of any other, so that one example will suffice to make clear the origin of all lichens.

\section{THE ORIGIN OF A LICHEN.}

As to the time when the first lichen was formed nothing definite is known. We may, however, safely - conclude that they existed in the geological periods along with algæ and fungi. We are certain that they could not have existed before the development of fungi, as explained above; we also know from what has gone before that algæ antedate fungi, from which we conclude that lichens began their existence many ages later than the first algae and fungi. From the great structural and functional specializations that lichens have undergone, we must again conclude that they began their existence far back in the geologic ages, that is, millions of years ago.

If we select one of the foliose Parmelias as a type, the hypothetical assumption is that its origin was as follows: A sac-fungus (Ascomycete) evidently belonging to the genus Patella, found it difficult to maintain a thrifty existence as a saprophyte; the organic foodsupply was no longer adequate to keep up suflicient energy to maintain a successful struggle for existence. 
The many generations of a life of dependent luxury had greatly crippled its energies; functionally it became more and more weakened, until finally it could not even digest a sufficient quantity of the food already prepared, or, in other words, it no longer possessed sufficient vitality to feed itself. In order to regain its lost vitality it must again appropriate a larger amount and better quality of food; inorganic food was not available, because it had lost its chlorophyll. -If the fungus could, however, prevail upon some chlorophyllbearing organism to prepare inorganic food-substances for its assimilation the problem would be solved; that is, it inust press into its service some plant having chlorophyll. As already indicated, ordinary parasitism with higher plants did not suffice: these plants were not sufficiently adapted to its needs. The fungus was therefore obliged to cast about for different plants, such as were specially suited to its physiological requirements. Splendid opportunities were offered in the numerous single-celled algæ (Protococcus vulgaris), known as "green mould," which everywhere covered trees, rocks, etc. The fungus made the attempt and entered into a biological relationship with this alga. It is highly probable that this first relationship was of a parasitic nature but the fungus soon found that these minute organisms were scarcely able to supply the extra food-materials demanded by the attaching parasite; the climatic conditions were not sufficiently favorable, and, furthermore, the alga itself showed a slight preference toward leading a parasitic life, so that the fungus was considered as a very undesirable intruder. 
If the organisms could in some way form an association mutually beneficial they would both be enabled to maintain the struggle for existence. This is what actually occurred: the two organisms seem to have made an agreement to assist each other. Whether this was a truly altruistic motive, or whether it was a case of necessity is rather difficult to determine. It was most likely a case of necessity; that is, the mutualistic association was compulsory in order to prevent extinction. No matter which was the prime motive, it remains a fact that the alga and fungus finally entered into an association which was mutually beneficial. This association is very different from parasitism (antagonistic symbiosis), and is recognized by scientists as a specialized form of mutualistic symbiosis, designated as individualism; the organisms which enter in to the formation of symbiotic associations are known as symbionts.

The relation of the symbionts under discussion (fungus and alga) was, in a sense, complementary : one supplied what the other lacked; there was a harmonious and equable assignment of labor ; each did that for which nature had best fitted it. In fact, we may draw therefrom a wholesome lesson. It should teach us to make that our life-work for which we are by nature best fitted so as to accomplish a maximum of good results.

As to the division of labor in the establishment of the lichen, the principal function of the fungus is to supply protection; that is, a mechanical function: the chief work of the alga is to perform the function of 
assimilation. The fungus gave protection to the algæ by forming a suitable covering to prevent sudden evaporation of moisture; it also served to conduct moisture and soluble food-substances and supplied suitable mechanical tissues to hold the plant firmly to the substratum (trees, soil, rock, etc.). The alga, due to its chlorophyll, assimilated the carbon dioxide $\left(\mathrm{CO}_{2}\right)$ of the air and formed organic compounds for the use of the fungus as well as for its own use. The mutual adaptations became more and more highly specialized, until, after many thousands and, perhaps, millions, of generations, a large foliose lichen was produced, as one of the higher Parmelias. This is, in brief, the probable history of the phylogenesis of Parmelia. At different periods other lower algæ entered into mutualistic associations with other sac-fungi. Each prototype developed in different directions, producing new species and finally, perhaps, distinct genera of lichens. Lichens did, therefore, not spring from a single ancestral alga and fungus, they are represented by a poly-ancestry.

Another remarkable thing is the fact that the agreement formed by a given alga and fungus was by no means permanent; after a long phyletic history a given lichen may have changed its alga, that is, the partnership was dissolved and another compact entered with a new alga. In many instances a new partner was taken in and the old was retained, so that we find some lichens with two algal symbionts.

From the above, it is evident that lichens are peculiar plants; they are the result of the mutualistic 
association of a fungus and an alga, two morphologically distinct organisms. We shall now consider somewhat more in detail the relation of lichens to both algæ and fungi.

II. THE RELATION OF LICHENS TO ALGE AND FUNGI.

In the historical review we have already indicated the varied positions given to lichens in the many systems of classification. Shortly before Schwendener's wonderful discoveries lichens were treated as a distinct class of plants, coequal in systematic importance with fungi, algx and mosses. Schwendener and his followers unhesitatingly classified them as fungi. Why? Because they looked upon lichens as fungi which were parasitic upon algra. Reinke, de Bary and others have, however, shown conclusively that it is not a truly parasitic relationship; as already indicated, it is an association mutually beneficial, known as mutualistic symbiosis. Schwendener's error was due principally to the fact that he misinterpreted the relationship and laid too much stress upon the spore-bearing structures. There are no more reasons why lichens should be classed as fungi than as algæ. In fact, the eminent scientist, Nägeli, classified them as algæ and Tuckerman in his earlier writings designates lichens as "aërial algæ." The eminent French lichenologist, Nylander, had already recognized the double affinity of lichens without realizing their true dual nature. In his system of classification he begins with those lichens most nearly resembling fungi, gradually proceeding to the highest foliose and fruticose forms, then forming a 
descending series with those most nearly resembling algæ. From these considerations, it is evident that the attempt to classify them either as fungi or algæ will lead to confusion. In agreement with Reinke, Darbishire and others, we have decided to treat lichens as a distinct class. The reasons for so doing will be given later.

In conclusion, we will briefly describe the algæ which enter into the formation of lichens. The figures of Plate I represent the algæ surrounded by the hyphal network of the fungal symbiont. The fungal types cannot be represented, for the simple reason that they are not known; the knowledge that they are derived from some groups of the sac-fungi must suffice for the present. The general belief is that the fungi which originally entered into the formation of lichens no longer exist. There are, however, fungi now living which resemble the fungal symbionts of certain lichens; for example, the representatives of the fungal genus Hysterium closely resemble the fungal symbiont of the lichen-genus Graphis.

I. Chlorophyces. - The algæ belonging to this group are distinctly bright-green. The following are the species which enter into the formation of lichens, given in the order of the frequency of occurrence.

1. Cystococcus humicola. This is a unicellular alga occurring in far the greater number of lichens. The cells are spherical. (Fig. 1.)

2. Chroolepus umbrina. This alga forms short 
branching chains of rather oblong irregular cells bearing brownish substances known as pyrenoid bodies. (Fig. 2.)

3. Pleurococcus vulgaris. A single-celled alga of rather irregular outline. It sometimes has a bluish tinge. (Fig. 8.)

4. Gloocapsa polydermatica. This is also a singlecelled alga. It differs from the preceding in that each cell is enclosed by a thick, transparent, gelatinous membrane. (Fig. 4.)

5. Dactylococcus infusionum. A single-celled alga. The cells are comparatively small and regularly elliptical ; they are usually associated in colonies of eight or ten cells. (Fig. 7.)

II. Cyanophycee. - The algæ of this group differ from the chlorophycer in their blue-green color.

1. Nostoc lichenoides. This alga occurs in chains of rather sinall cells. Each chain contains one, rarely more, larger cell known as a heterocyst. Each chain is enclosed by a gelatinous substance. (Fig. 3.)

2. Rivularia nitida. This alga also occurs in chains, but its cells are irregular in form. Gelatinous substance present. (Fig. 5.)

3. Polycoccus punctiformis. The cells of this alga are elliptical and occur in colonies enclosed by a common covering. (Fig. 6.)

4. Sirosiphon pulvinatus. This is a many-celled brauching alga of sufficient size to be seen by the naked eye. It occurs in the lichen-genus Ephebe. (Fig. 9.) 
These brief references to the algæ, with the accompanying illustrations, will suffice at present, as they will again be mentioned in the discussion of lichengenera.

III. LICHENS AS MORPHOLOGICAL UNITS.

We shall now briefly summarize those characteristics which distinguish lichens from other plants, fungi and algæ in particular. This is very necessary in the present state of our knowledge of lichens, as the influence of Schwendener's teachings is as yet very strongly felt.

Lichens macroscopically considered present such a peculiar appearance that the most superficial observer is led to believe that they form a group by themselves. They occur in places where neither alga nor fungus could exist alone. They have wonderful powers of resisting extremes of temperature ; freezing only checks their growth; a temperature of $-40^{\circ} \mathrm{C}$. does not kill them. They will resist a temperature of $60^{\circ} \mathrm{C}$. for an hour or more. They can tide over periods of di'yness which would invariably be fatal to either alga or fungus if existing alone.

The two symbionts form a microcosmos which is enabled to perform the life-functions originally inherent in both, and, in addition, the lichen has acquired new structural and functional characters during its phylogeny. The morphological adaptations are primarily for the furtherance of the function of assimilation, while among fungi the structural adaptations are primarily for the furtherance of the function of reproduc- 
tion. The method of reproduction in lichens is wholly different from that of fungi as well as algx. It is, however, true that the spores of lichens have a close morphological resemblance to the spores of certain fungi, but functionally they differ widely. The spores of fungi can develop into new spore-producing individuals, while the spores of lichens cannot produce new lichens unless associated with the essential algæ, which proves that the fungal symbiont can no longer mature independently. Some of the lichen-algæ have been induced to exist independently, but it is evident that some cannot. Lichen-spores are simply the functionally degenerate reproductive organs of their fungal ancestors.

As already indicated, fungi are essentially parasitic and saprophytic. Lichens have partially or almost wholly lost the saprophytic and parasitic function and have acquired the power of converting inorganic substances into organic compounds. The thallus of lichens is structurally and functionally comparable to the leaf of higher plants; fungi have no thallus, nor do they have any functional resemblance to the leaves of higher plants.

Lichens also contain chemical compounds not found in fungi or algx. Among these, lichenin (lichen-starch) is the most important; others are various acids (evernic, cetraric, etc.) and bitter extracts, coloring substances, and other compounds as yet not well known.

The typical reproductive organs of lichens are the soredia. These are in reality miniature thalli especially adapted to serve as propagative organs. They 
are formed of the elements of both symbionts and can therefore develop into a new lichen. Their structure aud function will be more fully described elsewhere. Lichens are also more long lived than fungi. The majority of fungi terminate existence with the maturation of the spores, while most lichens have an indefinitely prolonged existence. Some of the Cladonias, for example, may live hundreds of years ; the apical portion continues to grow, while the basal portion dies away.

Sufficient reasons have been given to show that lichens are neither fungi nor algæ; they must therefore be treated as a distinct class of plants. Other characters peculiar to lichens will be mentioned later. 


\section{SECTION IV.}

\section{THE MORPHOLOGY AND PHYSIOLOGY OF LICHENS.}

WE have already explained, in a general way, the morphological structure and the functional activities of lichens. We shall now enter into a somewhat more special comparison of the different lichen-forms. 'This is necessary to a better unlerstanding of the relative functional activities of lichens and their tendency in the scale of evolution. We will find that the higher lichens are more highly specialized as chlorophyllbearing organisms, and that the evolutionary tendency is away from the forms resembling fungi. We will find that there is a reduction in the spore-producing function, accompanied by an increase in the assimilative function.

\section{THE THALLUS.}

The thallus of lichens is the purely vegetative portion of the plant. It performs the function of assimilation, and in it the phenomena of growth are actively manifest. It is comparable to the vegetative portion of other cryptogams, sucl as mosses and liverworts. In its gross appearance and general texture, it is, however, very characteristic; so that a very casual acquaintance with lichens enables one to distinguish them from all other thallophytes, as the lower flowerless plants are technically known. 
From what has already been said of lichens, the reader knows that the thallus is functionally wholly different from the vegetative portion of fungi. The main difference may be stated as follows: In fungi the structural development and arrangement of tissueelements, of the vegetative portion, is for the special purpose of furthering the function of reproduction, that is, to supply a suitable structural arrangement for the maturation and distribution of the spores. In lichens the structural development and arrangement of the tissue-elements is for the special purpose of furthering the function of assimilation.

Structurally and functionally, the thallus of lichens is also analogous to a foliage leaf of higher plants. This becomes apparent on comparing vertical sections. The upper and lower cortical layers of the thallus are functionally analogous to the upper and lower epidermis of the leaf; the algal layer of the thallus to the palisade tissue of the leaf ; the medullary tissue of the thallus to the spongy tissue of the leaf. The analogy is, in fact, very striking, particularly between foliose thalli and the ordinary flattened foliage leaves. Fruticose thalli are analogous to leaves with "isolateral" or "centric" structure. Crustose thalli are in reality rudimentary foliose thalli, and are, therefore, remotely analogous to ordinary foliage leaves.

For practical purposes, the thalli of all lichens may be divided into three types or kinds, namely, crustose, foliose, and fruticose. Their structural differences are as follows : 


\section{The Crustose Type.}

This thallus occurs in the lower lichens, that is, in those in which the evolutionary specializations as lichens are not yet highly marked. In its simplest form it consists merely of a network of hyphæ in which are suspended a few alga; it may occur on the substratum, or wholly, or partially, beneath its surface. There are no distinct layers, in fact, in many instances it is almost impossible to detect any thallus whatever. Such rudimentary thalli occur in the lower species of Calicium, Pyrenula, Trypethelium, Xylographa, Arthonia and other genera.

The higher crustose thalli are quite thick, as in Lecanora, Pertusaria, the southern representatives of Graphis, in Baomyces, and other genera. The surface is often warty or the entire thallus is marked off into many-sided areas or areoles and is therefore spoken of as areolate. In higher crustose thalli we find the tissue-elements arranged into distinet layers, as seen in a vertical section. The upper layer consists of hyphæ and constitutes a protective covering for the layer of algæ just beneath. The algæ are inclosed by specialized branches of hyphæ, spoken of as haustoria. Below the alga occurs another layer of hyphæ which attach the thallus to the substratum and assists in taking up soluble food-substances. The hyphæ forming the upper layer, the haustoria, and the lower layer are continuous, and are part of the same hyphal tissue. In many instances the upper layer becomes more or less distinctly cortical, thus resembling the upper layer of foliose thalli. In fact, very often it 
is difficult to determine whether a given thallus is crustose or foliose. A typical crustose thallus is always closely adnate to the substratum and never has a lower cortical layer; the margin sometimes becomes lobed, as in some representatives of Placodium.

It is questioned whether many of the lower crustose lichens should not be classified as fungi. If a thallus is present, no matter how rudimentary, it is unmistakably a lichen; it must be remembered that careful search is often necessary to detect such rudimentary thalli, as in Pyrenula and other genera. (Plates II and IV.)

\section{The Foliose Type.}

Most of the lichens with which the amateur collector will come in contact belong to the foliose type. As a rule, the thallus is large, consisting of branching lobes which are only loosely attached to the substratum. In some instances the thallus is entire, varying from very small, as in Dermatocarpon and Psora, to very large, as in Umbilicaria and Gyrophora. One thing must be kept in mind and that is the fact that the foliose type merges into the fruticose type in the ascending series, and into the crustose type in the descending series. The characters here given refer to the more typical forms as represented by the Parmelias, Physcias, Stictas, Stictinas.

If we make a vertical section of the thallus and examine it under the microscope we find the following structures.

1. Upper Cortical Layer. - This consists of a compact tissue of short-celled hyphæ. It forms a pro- 
tective layer for the tissues beneath and also supplies mechanical support to prevent the breaking or tearing of the thallus due to winds and other external forces. The upper portion of this layer is sometimes colored, due to a deposit of acid crystals. The function of this colored substance is, perhaps, twofold: it probably modifies the influence of sunlight, and keeps away animals which feed upon lichens, such as snails. The thickness of this layer varies greatly in different lichens. The layer is of ten not uniform in thickness, even in the same plant; for example, in Peltigera it is alternately thicker and thinner, and shows a remarkable double adaptation - to supply the required mechanical support, and at the same time allow the algæ to approach nearer the surface for the purposes of greater chlorophyllian activity (carbon assimilation).

2. Algal Layer. - This lies beneath the layer just described, and consists of a loose network of hyphæ in which the algæ are suspended. It is the layer in which carbon assimilation is carried on. Certain hyphal branches, the haustoria, enclose and even penetrate the algæ, and take from them the assimilated food-substances required by the fungal symbiont, while the alga in return receives water and certain soluble food-substances from the fungal symbiont.

3. Medullary Layer. - This consists of a very loose network of hypha. It contains air, and therefore the carbon dioxide required to carry on the function of assimilation. The thickness of this layer varies considerably.

4. Lower Cortical Layer. - When present it re- 
sembles the upper cortical layer, usually it is deficient, and in a number of genera it is wholly wanting. When wanting, its place is taken by a tissue of hyphæ which extend longitudinally. From the lower surface, whether cortical or not, the rhizoirls extend. These are hyphæ, either single or in groups, which grow vertically downward into the substratum; they sometimes remain aërial and perhaps serve to retain moisture or to keep off crawling insects and snails. Usually the rhizoids are colored black. The cilia at the margin of many foliose thalli are morphologically and functionally analogous to aérial rhizoids. (Plates II, III and IV.)

\section{The Fruticose Type.}

The fruticose thallus differs from the preceding in that the lobes of the thallus are distinctly ascending and are not attached to the substratum. The entire plant is attached at a central or basal point known as the umbilicus. It must, however, be remembered, that the umbilicus is also present in some foliose thalli, as Umbilicaria and Gyrophora. The umbilicus consists of a hyphal tissue, and is analogous to the roots of trees, holding the plant firmly attached to the substratum and taking therefrom moisture and soluble food-sub-. stances.

The lobes of the thallus are usually much branched, and vary from distinctly flattened to cylindrical. The highest and most perfect type is, no doubt, represented by Usnea barbata.

In the flattened fruticose thallus we find the following tissues, which are essentially like corresponding 
tissues of the folinse thallus: 1. Upper or inner cortical layer ; 2. Upper or inner algal layer ; 3. Medullary layer; 4. Lower or outer algal layer; 5 . Lower or outer cortical layer. Rhizoids are not present; cilia may occur, as in Cetraria islandica.

In the cylindrical fruticose thalli, all the tissue-elements are arranged in a cylindrical fashion. The central portion may be hollow, as in Cladonia and Pilophoron, or solid, as in Usnea. This arrangement of tissue-elements is in accordance with mechanical principles, giving the required support to the usually large thalli. (Plates II and IV.)

\section{THE APOTHECIA.}

The apothecia are the spore-bearing structures developed in or upon the thallus. They are structurally very similar to the spore-producing organs of fungi (Ascomycetes, sac-fungi) but functionally, the similarity is not so close. Among fungi, each spore is capable of developing into a mature spore-producing plant; that is, it is the true reproductive element of the fungus. In lichens it is essentially different; here the spore cannot develop into a new spore-producing plant for the simple reason that the spore and its product represents only a part of the lichenautonomy ; that is, the germinating spore must be associated with the requisite algre before a new lichen can develop. This difference is very important and should be kept in mind when comparing lichens and fungi. The spores of lichens are functionally degenerate, reproductive organs derived from the fungal ancestor 
which entered into the formation of the lichen or lichen-group under consideration. The typical reproductive organs of lichens are the soredia, which shall receive consideration in another chapter.

The apothecia have undergone certain changes during the phylogenetic history of the lichen. These changes are primarily for the furtherance of the function of assimilation, rather than that of spore-formation. This is naturally to be expected since the spores are of little value as reproductive organs. Many of the higher lichens are constantly sterile. In some, the original apothecial structure has been converted into an assimilating organ, that is, a thallus. The vertical thallus of the Cladonias, usually known as the podetium, is doubtless such a modified apothecial structure. Again, the "cup apothecia" of some lichens have become greatly expanded, and contain within their interior algæ, thus acting as assimilating organs. In others, particularly the lower forms, the apothecia retain the structural characters of their fungal ancestors; that is, they do not bear algæ, and hence do not take part in the function of assimilation. Upon the presence or absence of algæ are based the distinctions into fungal and thalline apothecia.

\section{The Fungal Type.}

This apothecium is in all respects similar to the apothecium of an Ascomycetous fungus. The algæ of the algal layer of the thallus do not enter into its formation. It may be cup-shaped, as in the Discomycetes, or immersed, as in the Pyrenomycetes. In the 
former case, the following structures are discernible in a vertical section. The uppermost layer forming the disk, consists of the spore-sacs and paraphyses. The former are specialized hyphr which contain the spores; the latter are also specialized hyphæ, placed vertically, like the spore-sacs, but are much more slender and do not contain spores. This layer is known as the thecium; the spore-sacs are also known as thece or thekes. The term spore-sacs is, however, preferable, as it expresses more clearly what they are. The upper ends of the paraphyses are frequently colored, as brown, black, scarlet, yellow, etc., giving the disk its characteristic color, as discerned by the naked eye. Below the thecium occurs the hypothecium, which consists usually, of closely united hyphæ, generally extending at right angles to the spore-sacs and paraphyses. This tissue is more or less cup-shaped; in the Pyrenomycetous type, it formes a sphere, enclosing the thecium. In some cases it is convex, rather than concave or cupshaped, as in Cladonia and Breomyces.

If we have made our section from near the margin of the cup, we will find the following additional tissues. 1. Medullary tissue similar to, and continuous with the medullary tissue of the thallus. 2. Cortical tissue similar to and continuous with the upper cortical layer of the thallus. Sometimes this layer is not cortical. (Plate IV.)

\section{The Thalline Type.}

This differs from the foregoing in that the algal layer of the thallus extends into the apothecium, 
usually forming two layers; one immediately underneath the hypothecium, and the other just above the lower cortical layer of the apothecium. The algæ may approach quite to the margin of the cup, or they may extend only a part way up. In fact, there are all gradations, from the purely fungal type to the most highly developed thalline type as it occurs in the Parmelias and in Usnea. In general it may be stated that the fungal type occurs in the lower lichens, while the thalline type occurs in the higher lichens. There are, however, important exceptions to this rule. Figs. 1 to 5 of Plate IV will serve to illustrate the differences between the types just discussed.

\section{ACCESSORY STRUCTURE.}

The thallus and apothecia constitute the most important lichen-structures; there are, however, a number of other structures which occur on the thallus, and which are of more or less importance in the licheneconomy, and for that reason it is well that the student should be somewhat familiar with them. They are here discussed in the order of their importance :

\section{The Soredia.}

Examination of the upper surface of the thallus of many lichens reveals patches of a powdery or mealy substance. These patches may be circular or linear, especially along the margin of the thallus. If some of this powder is placed under the microscope and examined, it is found to consist of small irregular bodies made up of a hollow network of hyphæ, in the 
interior of which algæ occur. Each body is in reality a miniature thallus, and is capable of developing into a new lichen should it find a suitable lodging-place. It is the true propagative organ of lichens. The majority of lichens depend almost wholly upon this method of reproduction.

It is well to bear in mind that lichens are also propagated in a purely vegetative way ; that is, a portion of a lichen-thallus, or even the entire thallus, may be torn away and carried to a new locality, where a portion of it will develop into a new lichen. Some lichens also possess what may be designated as continuous rejuvenescence ; that is, there is continuous apical growth, accompanied by a continual dying away of the older portion. This phenomenon occurs typically in the higher Cladonias as well as in Thamnolia, and is also met with in the higher foliose lichens, as Parmelia. The central, hence older, portion dies away, while the margin continues to grow, producing an appearance not unlike the "fairy rings" of certain mushrooms. Nevertheless the soredia constitute the most important means of propagating lichens. They are developed from the algal layer of the thallus, finally pushing their way through the upper cortical layer to the exterior. Each body is known as a soredium; a collection of them forming one of the patches above mentioned is designated as a soralium, plural soralia.

\section{The Cyphella.}

Upon examining the lower surface of the thallus of a Sticta or Stictina there will be found a number of 
lighter-colored specks, somewhat smaller than a pinhead; these are the cyphella and are functionally analogous to the stomata or breathing pores of true foliage leaves. Structurally there is no resemblance; they are simply breaks in the lower cortical layer, filled in by a loose secondary cortical tissue. Upon examining them with a hand-lens, it will be found that they are of two kinds: one which appears as a depression, that is, concave; the other is somewhat protruding or convex. They occur only in the genera indicated.

\section{The Cephalodia.}

These are wart-like outgrowths, usually occurring on the upper surface of the thallus. Sometimes they also occur on the lower surface, as in Sticta Oregana. They are simply neo-formations in the tissue of the thallus, induced by a foreign alga. They occur upon various lichens, but are, perhaps, most common among the Peltigeras and Stictas. In Peltigera aphthosa they are very numerous and are about the size of a pin-head. In Sticta Oregana they vary from very small to nearly the size of a pea: These two plants also typify the two kinds of cephalodia. In Peltigera they develop upon the thallus, while in Sticta they develop within the thallus. Nothing definite is known regarding their origin and function.

\section{The Spermagonia.}

These are very minute cup-shaped structures, immersed in the upper surface of the thallus. To the naked eye they appear as minute black specks. Noth- 
ing definite is known regarding their function. Some investigators suppose them to be the male reproductive organs of lichens; others are inclined to look upon them as parasitic fungi. Many lichenologists have made the sad mistake of considering them as of great importance in classification; as such they are of little significance, because they are too variable in their occurrence, and too closely similar in structure. The socalled Pycnidia are closely related to the Spermagonia.

It is not at all likely that the reader will care to make any careful examination of the spermagonia. Should he, however, do so, he will find that each spermagonium resembles a small apothecium. In place of the thecium occur hyphal branches (sterigmata) on which minute acicular or rod-shaped bodies (spermatia) are borne. 


\section{SECTION V.}

\section{THE OCCURRENCE AND DISTRIBUTION OF} LICHENS.

THE actual number of species of lichens occurring on the entire globe is not known. According to $\mathrm{Ny}$ lander, about 1,500 species were recognized in 1858; between 4,000 and 5,000 species and varieties were recognized in 1892, according to Hué. The United States contains perhaps between 800 and 1,000 species. It must, however, be remembered, that all estimates are more or less unreliable. Many years of careful study are required in order to get at reliable data regarding the actual number of lichen-species.

I. THE LATITUDINAL AND ALtitudiNAl DISTRIBUTION OF LICHENS.

Lichens extend to the far north, where, with a few mosses, they form the most advanced outposts of vegetable life; they extend within a short distance of the northern snow limit. In the high arctic regions they constitute the characteristic flora of the country. Here they occur mostly as earth-lichens and rock-lichens, different species growing in close association, forming what are technically known as "lichen-tundra." The great majority of species belong to the genera Cetraria, Cladonia, and Evernia. The cause for their occur- 
rence as earth-lichens is quite evident, as scarcely any other substrata exist; trees, fences, and the like being wanting. In the more temperate regions we find earth-lichens, rock-lichens and a considerable number of tree-lichens. In the tropics tree-lichens predominate, owing to the greater competion for space. The richness of vegetation of all sorts, trees among the rest, makes it evident that vegetable substrata are, in a sense, forced upon the lichens. In fact, the intimate associations of plants with plants and of animal with plants, etc., are much more prevalent in the tropics, for similar reasons. The great struggle for existence necessitates the establishment of mutual adaptations as well as antagonism or parasitism.

Some lichens have a limited range, while others are truly cosmopolitan, such as Cladonia rangiferina, Usnea burbata, Lecanora subfusca and others. As to substrata, some species are limited to a given rockformation, while others occur upon different rockformations as well as upon trees, and even soil, such as many of the Parmelias and Pliyscias. Trees (bark), rocks and soil are the principal substrata for lichens; they are also common upon dead (not rotten) wood, such as fences, roofs of buildings, etc. Exceptionally they have been found growing upon rotten wood, old leather, bones, glass, iron railings, etc. Some are truly parasitic upon the green leaves of plants in the tropical and subtropical regions.

Crustose lichens very frequently encroach upon each other, the stronger and more rapidly growing species finally spreading over and destroying the less resist- 
ing species. The same thing occurs among foliose and fruticose lichens. A great many lichens show a decided preference for mosses, over which they spread in considerable profusion, finally killing the mosses, not so much as the result of drawing any nourishment from them, but rather as the result of mechanical interference and the shutting off of air and sunlight.

In general it may be stated, that lichens occur plentifully from the northern limit indicated to the tropics. Some lichens are essentially southern, others northern

$\checkmark$ or western. Only a very few are typically eastern.

It is quite important that the collector should have some knowledge of the vertical distribution of lichens; this will avoid much waste of time in searching for lichens in places where they do not occur. For example, Gyrophoras and Umbilicarias do not occur at slight elevations; in fact, the lowlands yield only comparatively few lichens. As a rule, lichens which occur at low levels in the arctic regions also occur at high altitudes in the warmer or tropical regions.

As already indicated, mountainous timber regions yield the most numerous and finest specimens of lichens; prairies and open lowlands yield the poorest and fewest. It also seems that there is a narrow belt in the immediate vicinity of the coast which is deficient in lichens; this is perhaps due to excessive moisture, which is detrimental to their existence. We have elsewhere indicated that lichens flee from civilization. The reasons for this are not definitely known; it is very likely due to the dust and smoke (impure atmosphere) of the cities; they require pure air for their 
existence. One need, therefore, waste no time in looking for a rich harvest of lichens in city parks, along much-travelled roadsides, in woods that are frequently run over by cattle, sheep, and other animals. Seek the highest and wildest hills in your locality; if there are none, search through the timber-lands; if that particular locality is without hills, mountains, and timber, devote yourself to the orchard, the fences, old buildings, trees along roadsides, etc. Make the best of your locality and make excursions to other more favorable areas. Further particulars in regard to the occurrence of lichens will be given in the description of genera and species. 


\section{SECTION VI.}

\section{LICHENS AND THE NATURALIST.}

IT is hoped that, from the consideration of the preceding chapters, the reader has obtained a fair knowledge of the true nature of a lichen, so that there will be no difficulty in recognizing at least the higher forms. The origin and structure of lichens has been explained, so that there is no excuse for confounding them with fungi or mosses, or to designate them as "dead things," "excrescences," or "nothing much." Each lichen will bring up some association, with the history of its evolution, its treatment in the hands of the botanists of the past, its uses in the arts and in medicine, its relation to other plants, its work in nature, etc. All this will serve as food for thought while on a collecting trip. It is now our purpose to indicate briefly how to collect, study and preserve lichens.

\section{THE COLLECTION OF LICHENS.}

Lichens may be collected all the year round, but there are seasons which are more suitable than others; such as late in the summer and in the autumn, because then the thalli and the apothecia are at their best. The great majority of lichens live from year to year, and can, therefore, be collected at any time; some begin development and mature in one season, such as the 
Collemas; these in particular should be collected in the fall.

Having decided upon the most favorable season for collecting, we find that there are days and portions of a day which are particularly suited for this work. Just after a rain lichens show their brightest colors and become greatly enlarged, owing to the absorption of water. At this time the foliose and fruticose lichens are not in the least brittle; they can be bent or rolled without any danger of breaking them. In the morning and early forenoon is the next best time in which to collect. The worst period of a bright day is at noon or in the early afternoon between twelve and three o'clock. Quite early in the evening lichens again take up moisture and lose their brittleness. In the case of crustose rock and tree-lichens, the moisture or dryness of the thallus is of no consequence; they might, therefore, be collected during dry weather, or during the dry periods of the day. Foliose and fruticose rocklichens lose their moisture first, next come the treelichens, and last of all the lichens of the soil.

No expensive or complicated outfit is needed to collect lichens ; cumbersome and not absolutely necessary traps should not be carried about. We will briefly describe the equipment of a collector who intends to put in a day's work in a locality where lichens are quite plentiful. As to the clothing to be worn, it need not, of course, be explained that it is not a dress-suit affair; put on good stout old clothing, a broad-brimmed felt hat, and stout shoes with thick soles. It is well and advisable to carry along a lunch, and, above all, make 
plans to enable you to secure a drink of water ; if you know of a spring, that is just the thing, keep it in mind and head for it at the appropriate time; if no spring exists in the locality, head for a farm-house. Never drink out of small brooklets, especially in inhabited localities: there is always more or less danger of becoming infected with some disease germs, or perhaps some intestinal parasite. The collecting outfit may . be divided into three groups, as follows:

1. Contrivances for carrying lichens.

2. Mechanical aids in collecting.

3. Aids to a temporary study of lichens.

1. The most convenient contrivance for carrying lichens is the botanist's collecting-can, more technically known as a vasculum. This can, however, only be secured ready-made from dealers in botanical supplies. Any tinsmith can make one to order, for perhaps $\$ 1.00$, or $\$ 1.50$, provided it is explained to him how to make it. The most convenient box for collecting lichens should be rectangular, with corners rounded, made of heavy tin. It has a door at the side or top. It should have a coat of black japan on the outside to prevent the annoying reflection of sunlight. The size of the box can be left to the taste and needs of the individual. If a botanical collecting-box is not convenient, an old hand-satchel will do very well, in fact, in many respects it is superior to the tin box.

It is supposed that the collector intends to bring home crustose rock-lichens and crustose tree-lichens as well as foliose and fruticose lichens. The rockspecimens should be wrapped in paper separately, to 
prevent abrasion, and placed in the bottom of the vasculum or satchel; on top of these place the bark-lichens, and finally, uppermost, the foliose and fruticose lichens. Or the rock and bark-lichens may be placed in the box as indicated, while the large lichens may be placed in a special folio made of two broad thin boards or heavy pasteboard, with a back and suitable handles. The lichens should be spread between folded sheets of paper (newspaper or any other), care being taken not to crush them while dry; if dry, moisten them, when . they may be pressed in any position without injury.

2. The collector will require the following instruments to aid him in securing specimens: $a$. A good, large jack-knife for securing bark-lichens, especially the crustose forms. This should be quite sharp and may be carried in the pocket. $b$. A hammer of medium size, and a cold-chisel of medium size for securing crustose rock-lichens. These might be carried in a leathern pouch, such as is used by geologists, which would also serve to carry the rock-specimens. c. A carpenter's chisel, or a table-knife, will be found convenient for removing large foliose lichens from rocks, fences and trees.

It now only remains to give some general advice as to where and how to collect. From what has been said of the distribution of lichens, it is known that mountainous and wooded districts yield the richest harvest; thickly populated and open districts are the poorest in the variety of fine specimens. It is never advisable to proceed from a poor district to one rich in species. It is only a waste of time and energy to 
collect poor, scrawny specimens, which will be cast aside as better material is found. It will, of course, not be necessary to urge the advice not to begin the collection with the more insignificant crustose forms; the beginner will only too gladly leave these alone. For some time attention should be devoted to the larger foliose and fruticose lichens and to collect fertile material in so far as that is possible. It must, however, be remembered that some lichens rarely or never bear apothecia. These may be collected and retained until the fertile forms have been studied, when little difficulty will be found in classifying them, at least generically.

iichens occur in nearly all places where there is not too much constant moisture and shade. They are most numerous on the "weather-side" (northern exposure) of trees, fences, old roofs and stone walls. Travellers and hunters have time and again utilized this knowledge to guide them in their journeys. Large specimens of lichens occur on the bleakest rock; fine specimens of Cladonia occur on the soil in comparatively open ground; some large foliose species (Peltigera) occur on the soil in shaded places. Breomyces $\sqrt{ }$ roseus, with its pink apothecia, which is quite striking in appearance although it is one of the crustose forms, also occurs on the soil.

From a study of the table of the continental range of lichens one can obtain some idea as to what genera may possibly be met with in a given locality. A collector in the eastern, southern, or central states need waste no time looking for Rocella tinctoria, as this 
lichen occurs on the Pacific coast. Graphis, Arthonia and a few other genera are largely southern, etc. It is also well to fix in mind their altitudinal distribution, so that no time will be wasted in looking for lichens in the lowlands which occur only at considerable elevations.

In a general way it may be advised to begin the collection with the highest altitudes and to descend gradually, carefully examining trees, rocks and soil. Rocky ledges at high altitudes will be covered by large foliose and fruticose lichens, as well as a host of crustose forms. Some of the Parmelias may be several feet in diameter. If the rock is not too rough the lichen can be peeled off readily: begin on one side, with the carpenter's chisel, or the table-knife, gradually loosen it and roll the edge over, keep on, slowly and patiently, and you will succeed in removing it entire; if the plant is dry and brittle it will be necessary to moisten it with water before trying to remove it. After it is removed lay it flat between two sheets of paper and place it in the portfolio, or leave it rolled up and put it in the collecting-box. Umbilicarias, Gyrophoras, Stereocaulon, Cladonia and some others, will occasion no trouble in removing them from rock, as they are only loosely attached. If they are dry and brittle it is well to moisten them before handling much. Some difficulty will be encountered in removing foliose lichens from the bark of trees; usually only fragments can be obtained. The fruticose lichens, no matter where they occur, can be collected with but little difficulty. Crustose bark-lichens require the 
aid of the jack-knife or perhaps the carpenter's chisel and the hammer. Crustose rock-lichens require the use of the cold-chisel and the hammer. If the rock is stratified, or "chips" easily, no difficulty will be encountered, but if the rock is not stratified, for example, granite, the chisel is of little value; the best that can be done is to knock off fragments of the rock from the corners; it will be impossible to get thin specimens.

Each specimen, as it is collected, should be carefully examined with a lens carried for that purpose; search for apothecia, observe the color, size, and general contour; where does it grow - on rocks, trees, or soil? the altitude, locality, etc. These points, and others which may seem interesting, should be entered in a note-book; they will be found very useful in the subsequent study of the specimen. A leisurely collector may take with him a guide to the study of lichens and determine at least some of the material collected, but this is not at all urged, as the final studying of the material is to be done at home.

Collected material requires no immediate care. It may be kept tied up in bundles until wanted for study, or until it is intended to prepare the specimens for mounting. One thing must, however, be remembered : do not stow away large packages of lichens in a moist place, because in a few days they will be covered over with mould, thus ruining the specimens. Another thing to be guarded against, is not to keep thoroughly wet specimens wrapped in bundles for more than a few hours, as many species will change color, the result of chemical processes; this is particularly true of some 
of the Parmelias. In view of these facts, it would, therefore, be advisable to expose the collected material to sunlight until they are quite dry; they can then be safely stored away for an indefinite period of time.

\section{THE STUDY OF LICIIENS.}

About the first thing to be done with the collected material is to study it critically, with a view to determining the species. This can best be done at home, where the necessary apparatus and conveniences may be employed. It is also taken for granted that no previous experience has been had in identifying lichens.

Place the collected material on a convenient table; now sort the lichens into heaps, placing those that look alike together. Compare them carefully as to color, branching, size, and form of the apothecia, etc. Make liberal use of the pocket lens, and have the field note-book at hand for reference. If the specimens are dry and brittle moisten them by dipping in a basin of water; this will also restore their natural color. The number of heaps indicates approximately the number of species collected.

The next step in the procedure is to select one of the heaps of which the specimens have well-developed apothecia. It is preferable, in most instances, to begiu with fruticose forms, only it must be remembered that many of them are normally sterile, that is, they are without apothecia.

The next thing to be done is to determine the family to which the plant under consideration belongs. This can be accomplished with the aid of the key and 
diligent study of the description of families. The method of procedure in the identification of the genus depends somewhat upon whether or not a compound microscope is available. If a microscope is at hand the genus may be determined from the examination of the spores, and incidentally, also, the algæ. All that is necessary is to take very minute bits of the thallus and apothecium, tear them apart thoroughly, mount in water and examine. If the fragments are still too thick, carefully press upon the cover-glass, accompanying the pressure with a rotary motion of the finger; this will separate the tissue-elements sufficiently to permit their being seen distinctly. If no microscope is at hand, the only thing that remains to be done is to do the best you can without it; the "artificial key" is especially prepared for those who are without a compound microscope. No attention need be paid, in this latter case, to spore-characters and the algæ; make use of the family-characters and generic characters given in Part II.

After the genus is determined, it only remains to identify the species. This is done by referring to the descriptions of the species belonging to that genus. The beginner must not feel discouraged should he be unable to name all the species collected, it is not expected of him. The unnamed specimens should be kept for future study, or they may be submitted to an expert for identification. It is well to bear in mind that the expert cannot afford to do this work gratis; in perhaps most instances he will be satisfied with a duplicate set. 
It would also be advisable for the beginner to purchase a set of lichens already named by some good authority on lichens. A set of from fifty to one hundred lichens typical of the United States can be had for from five to ten dollars. These lichens would be found very useful as helps in the identification of most genera and species.

This general advice is intended to point out the way as to the procedure in the identification of species. Great patience is necessary. Do not expect impossibilities; if you determine one out of every six species collected you have done well; if you determine them all you are a genius and should make lichenology your life-work. In any case the mere name adds little to our appreciation of the lichen; it is the knowledge of its true relation to other things which makes it interesting.

\section{THE PRESERVATION OF LICHENS.}

Fortunately lichens are very easily preserved; they require less care than any of the other groups of plants. Some skill is, however, necessary to prepare a really fine collection, or herbarium, as it should be more technically called. Some collectors will no doubt find use for lichens for decorative purposes, but the prime object of the great majority of lichenologists in making collections will be to arrange them in some suitable manner, with the view to accumulating a lichen-herbarium of fine, large, well-preserved, well-mounted specimens. With this in mind, we shall consider especially the preservation of the foliose and fruticose lichens. 
The collected material usually has clinging to it various foreign substances, such as soil, leaves, twigs, moss, particles of bark and decayed wood, etc. It is desirable to remove these as far as possible. A little experience in cleaning them will teach how this can be done best and most expeditiously. Much of the soil, sand, and other substances can be shaken out; washing and rinsing in plenty of water will readily remove dust and dirt. Leaves, moss and twigs can be picked out with a pair of tweezers. Each specimen should be carefully cleaned. If the specimens have been washed, lay them where the water can drain off. All specimens should be moistened before they are pressed, but it must be remembered that there should be no excess of water present.

The next step in the procedure is to dry and press the cleaned specimens. For this purpose, sheets of blotting-paper are necessary, or, better still, the regulation dryers used by botanists. Place one of the sheets of blotting-paper or dryer on a piece of board or on a table, on this place a sheet of paper (newspaper will answer very well). Now take the moderately dry specimens (they must be sufficiently moist to be thoroughly soft and pliable) and arrange them as you wish them to appear in the collection. If a foliose lichen, of course the entire thallus is simply laid flat. If fruticose, arrange the branches as artistically (naturally) as possible. Cover the entire sheet, but do not place specimens over each other. Place another sheet of newspaper over the lichens, followed by one or two dryers, then begin with the arrangement of another 
layer of lichens, and continue this process until the entire collection of fruticose and foliose lichens is placed between dryers. On top of the entire pile place a board with a weight of from 20 to 25 pounds. For the first two days the specimens with the two sheets of newspaper should be transferred to dry dryers twice daily. For this purpose it is necessary to have two sets of dryers; the moist ones should be exposed to the sun while the others are in use. For the next three days they need be changed only once daily. At the end of five days the lichens are, no doubt, perfectly dry; they will be found permanently flattened and ready for mounting.

Lichens, like all other botanical specimens, should be mounted on the regulation mounting sheets of heavy glazed white paper. Fasten the specimens to the paper by means of glue (fish-glue). Arrange the specimens uniformily, but never place more than one species on a sheet. With foliose lichens, it is desirable to place two specimens side by side, one showing the lower surface and the other the upper surface. If the specimens are large, one will be enough to place on a sheet; if small, as many as five or six may be glued on. In this case it is advisable to select specimens from widely different latitudes and altitudes. .

As soon as the specimens are glued on the sheets they should again be placed between the sheets of newspaper and dryers, with pressure applied until the glue is perfectly dry, when they are ready to be placed in the herbarium with other specimens.

If mounting paper is not at hand, the specimen may 
be glued in a scrap-book or a blank book of a similar nature. In this case it is advised to follow some system; that is, place the specimens belonging to the same genus on successive pages and arrange the genera in the order they are given in the guide. If one scrap-book is filled, get another of the same kind and proceed as before. For the amateur the scrap-book method will prove most satisfactory; but if it is intended to accumulate an extensive or approximately complete collection, it is advisable to use the mounting sheets.

The specimens may also be glued on small pieces of heavy paper (bristol-board will answer very well). Later these sheets with the specimens may be glued on the regulation mounting paper, or in the scrap-book. In all instances space should be left to paste the label at the lower right-hand corner.

Crustose bark-lichens and the smaller specimens of crustose rock-lichens may be mounted at once. Remove unnecessary bark and rock, and make them as presentable as possible before mounting. Usually, rock-specimens are too heavy to be mounted on paper; they had best be kept in small pasteboard boxes, or in the paper pockets about to be described. In any case it is not at all likely that the beginner will care to make an extensive collection of rock-specimens.

Lichens may also be put up in paper pockets, especially those intended for exchange. A paper pocket is nothing more or less than a piece of heavy paper (manila or similar paper) folded in such a manner as to hold the specimen. They may be made as follows: Secure the right sort of paper, and cut or have it cut into 
suitable sizes. 'Take one of the rectangular pieces and fold it from the bottom to within an inch of the top; turn down the top one inch, so that the upper flap folds over the lower flap; now turn the sides under (or back) for a space of one inch, crease the edges well and the pocket is complete. It will, of course, be necessary to have assorted sizes of pockets, to suit the sizes of the different specimens; but do not make too many different sizes, three will, perhaps, be enough for all practical purposes. These pockets, with the specimens, may be glued on the mounting sheets or in the scrap-book; in which case the label is pasted on the outside of the lower flap, If the specimens are intended for exchange the labels should be placed on the inside with the specimen and not glued, so as not to inconvenience the one with whom you are making exchanges, should he desire not to mount them with the pockets. It must also be remembered that many crustose soil-lichens and some of the smaller fruticose forms can only be kept in pockets or boxes. There are also other styles of pockets than the one here described; perhaps the reader will invent a better and more convenient form.

Every specimen should be labelled; in fact, a specimen without a label is of little value from a botanical point of view. The label should be of sufficient size for the following data: Name, where collected (give a recognizable geographical locality), elevation, date when collected, and the name of the collector. Labels should either be printerl, or written with pen and ink. If labels are not at hand write the above items on the 
sheet or pocket; even if the name of the specimen is not known, do not fail to give the other data.

In conclusion, the following general advice may be found useful. Put up only good large specimens; scrawny, small specimens are not desirable unless they are the only kind obtainable in the locality. Mount a goodly number of duplicate specimens for the purpose of making exchanges. Make your exchanges with a view to mutual gain; to do this, it is necessary to make exchanges with parties in widely different localities; state what you have and ask for what you would like in exchange.

For mounting sheets, driers, labels, vasculums, in fact anything desirable in a botanical liné, enter into communication with some dealer in botanical supplies. Purchase only what is needed; use home material as much as possible. 
PART II

SYSTEMATIC STUDY OF LICHENS 



\section{SECTION I.}

\section{SYSTEMS OF CLASSIFICATION.}

In a general way it may be stated that one of the ultimate aims of science is to classify. It must not be supposed, however, that the mere naming and arranging of things is in itself the object in view. It is simply the means to an end; classification simplifies the work for those who follow: it, so to speak, represents the status of the science under consideration.

One of the most common errors that amateur scientists fall into is to suppose that a given system, we will say of a group of plants, is something fixed and abso-lutely reliable. This is by no means the case; every system, no matter how elaborate it may seem or by whom it may be proposed, is imperfect and subject to change as new discoveries are made. This, however, does not imply that the existing systems are useless. They are of inestimable value in so far as they represent the most reliable facts obtained in regard to the science under consideration. As soon as a system fails to be in harmony with the most alvanced and reliable investigations it will of necessity make way for a better system.

Two kinds of systems are usually recognized: one is known as the "artificial system," the other as the "natural system." In the former no attempt is made 
to show the natural relationship of the organisms, while in the latter an attempt is made to show the affinities of families, genera and species. If, for instance, all flowering plants are classified according to the differences in the leaves, we have a purely artificial system; in such a system it would be necessary to place together plants which have no close relationship; and, again, it would be necessary to separate others which are undoubtedly closely related. In the so-called natural system all the known characters are employed. In the case, for example, of the flowering plants, not only the leaf characters, but also those of the flowers, the seed, the stem, the histological and physiological differences, etc.

If we stop to consider, we find that the natural system is, in a degree, also artificial, for the simple reason that all of the facts regarding morphology and physiology, evolution, etc, are not yet known, and, so far as we know at present, never will all be known. Human knowledge is finite; it is, so to speak, hemmed in on all sides; what little we do recognize as "facts" has for its basis something which is taken for granted, and of which we therefore know nothing.

As regards the classification of lichens, it may be stated that a natural system is practically non-existent. Only within a few years have any efforts been made to show the natural affinities of the different lichens and lichen-groups. Heretofore, nearly every specialist on lichenology had proposed a new system, thus adding to the existing confusion. We now know that a lichen is a morphological unit, which resulted from the sym- 
biotic association of a fungus and an alga. Lichens, therefore, have a double affinity, being closely related to the fungi on the one hand and to alga on the other. Their true position is between the fungi and alga. They are a class of the cryptogamic (flowerless) plants devoid of stem and leaves. We have already discussed some of the structures of lichens which are analogous to certain structures of higher plants. This analogy does not indicate any close natural relationship. Lichens have no roots, leaves, branches, vascular tissue, epidermis, etc., as we find them in higher plants; the analogies are indeed very remote.

The present tendency in classification is to proceed from the lowest to the highest, from the less specialized to the more specialized, rather than from the highest to the lowest. This is the natural way, as by this method one can better explain the characters which indicate their relationship.

Since lichens are treated as a distinct class and not as fungi, the effort must be made to show their relationship to each other; in order to do this, we must also study their relationship to the fungi by endeavoring to find their probable fungal ancestors. Such attempts have recently been made by Reinke and others, but much remains yet to be done.

The amateur need not worry about the imperfections indicated; the systems at hand will suffice for the present; future generations will work with other systems. 


\section{SECTION II.}

\section{KEYS TO THE STUDY OF LICHENS.}

KEYS to a system of plants are of value, but this value is generally overestimated The usefulness of a key depends largely upon the one who makes it; if he has a thorough knowledge of the subject, he is generally able to construct a key which will be found highly useful by others. Any key, whether natural or artificial, should contain the fewest words possible consistent with clearness; close attention must also be given to co-ordination and subordination.

Two keys are here proposed: one, the artificial, intended for those who cannot secure the use of a compound microscope, and who are dependent upon the eye and a pocket-lens to aid them ; the second, a natural key, recommended to those who have a compound microscope at their disposal.

It will be noticed that in the artificial key the thallus and apothecia are of prime importance; in the natural key the algæ and spores are of first importance in the determination of genera. No attempt has been made to arrange keys to the species.

In the artificial key it was found necessary to combine several genera in some instances, because no marked macroscopic differential characters were noticeable. Furthermore, several insignificant genera have been wholly omitted. 
I. ARTIFICAL KEY TO THE MORE IMPORTANT GENERA OF LICHENS OCCURRING IN THE UNITED STATES.

\section{Thallus Crustose.}

Stipes present with terminal apothecia, plants small. Stipes and apothecia black.

A pothecia somewhat flattened (discoid) . . Cyphelium. Apothecia globose (spherical) . . . . Calicium. Stipes light colored.

Apothecia small, brownish, bark-lichens . Coniocybe.

A pothecia large, earth-lichens . . . . . Bøomyces.

Stipes wanting, apothecia more or less immersed.

Apothecia distinctly linear.

Length of apothecia usually exceeding four times their width; black or white . . . . Graphis.

Length of apothecia usually not exceeding four times their width ; black.

On decaying wood. . . . . . Xylographa.

On bark of trees . . . . . . Opegrapha.

Apothecia not linear, irregular.

Oval or oblong. . . . . . . Hazslinskya.

Irregular, not oval or oblong.

Disk distinctly visible, black.

Apothecia small . . . . . Arthonia.

A pothecia comparatively large . . Arthothelium

Disk indistinct, mostly immersed . . . Mycoporum.

A pothecia regular in outline.

Immersed in thallus or substratum; globose.

Not in colonies.

Disk light colored . . . . . . Pertusaria.

Disk black or dark.

Occurring on rocks . . . . Verrucaria.

Occurring on bark

Apothecia almost entirely covered

by substratum ...... Pyrenula.

Apothecia more elevated, urn-

shaped. . . . . . Gyrostomuri.

Apothecia crateriform . . . Thelotrema.

In colonies . . . . . . . . Trypethelium.

Immersed in thallus; not globose.

Disk not projecting above surface of thallus.

Thallus light-gray . . . . . . Urceolaria.

Thallus dark . . . . . Acarospora.

Disk projecting above the green thallus . Acolium. 
Apothecia discoid or semiglobose; sessile, not immersed. Disk black or dark.

Hypothecium black ${ }^{1}$. . . . . $\left\{\begin{array}{l}\text { Bacidia. } \\ \text { Lecidea. }\end{array}\right.$

Hypothecium colorless . . . . $\left\{\begin{array}{l}\text { Biatora. } \\ \text { Bilimbia. } \\ \text { Lecanora. }\end{array}\right.$

Disk orange to rusty-red . . . . . Placodium.

Thallus Foliose.

Thallus entire or lobes plicate, grayish-brown or dark.

Apothecia innate or immersed.

Apothecia comparatively large; innate in depressions of the thallus .......... Heppia.

Apothecia small, immersed.

Thallus simple, very minute, adnate, . Dermatocarpon.

Thallus about five $\mathrm{mm}$. in diameter, not closely adnate ....... . Psora.

Thallus large, umbilicate . . . . Endocarpon. Apothecia sessile, black; thallus large, umbilicate.

Thallus pustular ........ Umbilicaria.

Thallus not pustular . . . . . . Gyrophora.

Thallus distinctly lobed or branching, usually large.

Apothecia cup-shaped or discoid, sessile.

Cyphellæ present. ${ }^{2}$

Thallus blue-green to dark-brown, soredia yellow ........ Stictina.

Thallus greenish to light-brown, soredia not yellow . . . . . . . . . Sticta.

Cyphallæ wanting.

Thallus ash-gray, comparatively small.

Branching distinct, lobes of uniform width. . . Speerschneidera.

Branching less distinct, lobes not of uniform width . . . . . . Physcia.

Branching indistinct, thallus thin, closely adnate . . . . . . . Pyxine.

Thallus greenish, more rarely brown to dark, large . . . . . . . Parmelia.

Thallus brown, small, closely adnate . . Pannaria.

1 Make a vertical section through the apothecium and examine with a good pocket lens.

2 Sticta amplissima and S. pulmonaria are devoid of cyphellæ. 
Thallus distinctly blue-green to dark-blue, thin, highly gelatinous when moist.

Lower surface devoid of long rhizoids, $\left\{\begin{array}{l}\text { Leptogium. } \\ \text { Collema. }\end{array}\right.$

Lower surface bearing long rhizoids, thallus comparatively thick . . . Mallotium. Lower surface veined. . . . . . Hydrothyria. A pothecia innate, not cup-shaped.

On lower surface of upturned lobes . . Nephromium. On upper surface of thallus.

Thallus comparatively small, apothecia not marginal . . . . . . . . Solorina.

Thallus large, apothecia marginal . . . Peltigera.

\section{Thallus Fruticose.}

Thallus very minute, dark-blue, scarcely visible to the naked eye.

Apothecia terminal, more or less globose.

'Thallus-lobes distinctly flattened . . . Omphalaria.

Thallus-lobes not distinctly flattened. . . Lichina.

Apothecia lateral, discoid . . . . . Polychidium.

Apothecia within thallus . . . . . . . Ephebe.

Thallus distinct to very large.

Yellowish coloration in thallus or apothecia.

Thallus distinctly flattened . . . . Theloschistes.

Thallus not distinctly flattened . . . . Evernia.

Yellowish coloration wanting.

Thallus flattened, thick, not brown or dark.

Disk black, thallus gray to purplish . . Rocella.

Disk not black, thallus greenish . . . . Ramalina.

Thallus flattened, thin, brown to dark . . Cetraria.

Thallus cylindrical, hollow.

Apothecia terminal.

Disk black. . . . . . . . Pilophoron.

Disk brown or red . . . . . . . . Cladonia.

Thallus cylindrical, solid.

Branches long, pendulous.

Color green to grayish-green . . . . Usnea.

Color dark to black . . . . $\left\{\begin{array}{l}\text { Bryopogon } \\ \text { Alectoria. }\end{array}\right.$

Branches rigid, erect.

Smooth, shiny . . . . . . Spharophorus.

Not smooth, warty. . . . . . Stereocaulon. 


\section{NATURAL KEY TO THE FAMILIES.}

The natural keys to the genera are given after the description of the families. In the use of the natural key to the families and genera, the beginner is dependent upon the use of the compound microscope. The student is advised to keep in mind the suggestions given in the chapter on "The Study of Lichens."

\section{KEY.}

Algæ of the thallus bright-green.

Fungal type of apothecium.

Apothecia terminal on stipes or on the fruticose thallus.

Disk closed, finally opening by a terminal pore or crevice . . . . . . . . I. CALICIACEE.

Disk open, convex, light-brown or red,

II. CLADONIACEA.

Apothecia sessile on the crustose or foliose thallus.

Disk cup-shaped, flattened or convex, brown or black, III. LECIDEACEA.

Apothecia linear, irregular or stellate; thallus crustose . . . . . . . . IV. GRAPHIDACE E.

Thalline type of apothecium or apothecia immersed in the thallus.

Apothecia discoid and sessile, rarely immersed.

Plasmic masses of spores united, spores two-celled,

Plasmic masses of spores not united, V. PHYSCIACE E. VI. PARMELIACE E.

A pothecia immersed in the substratum or thallus, opening by a minute pore, VII. VERRUCARIACEA. Algæ of the thallus blue-green. ${ }^{1}$

'Thallus foliose, dark-blue, gelatinous when moist, VIII. COLLEMACEA.

Thallus minutely fruticose or foliose, not gelatinous when moist . . . . . . IX. PANNARIACE E.

The descriptions of the families and genera will be made as brief as possible. Those who wish to study

1 The following genera of the Pannariaceæ have bright-green algæ; Nephroma, Solorina, Sticta and Psoroma. 
the affinities of the various groups are referred to more complete works on the subject. It is intended to devote most attention to the description of the species, dwelling particularly upon the points of historical interest, thus rendering the subject less dry and monotonous.

An attempt has been made to arrange the gevera and species in a natural order beginning with the lowest.

\section{CALICIACEAE.}

With comparatively few exceptions, the representatives of this family are insignificant in appearance. The thallus is either crustose or fruticose. The apothecia are globose and terminal upon the stipes or on the branches of the fruticose thallus. A stipe is a small, simple, erectstalk devoid of algx, hence is not a part of the thallus; it is an apothecial stalk bearing the apothecia.

Upon an examination of the Caliciacex, it will be found that the spore-sacs dissolve and set free the immature spores which lie above the thecium and are covered over by the exciple (proper exciple). Finally, there is a rupture of the apical portion of the apothecium, setting free the spores.

None of the representatives of this family have any special historical interest.

Thallus crustose.

\section{KEY TO TIE GENERA.}

Apothecia terminal on slender stipes.

Spores simple, colorless . . . . 1. Coniocybe.

Spores two-celled, dark . . . . . . 2. Calicium.

Spores simple, lark . . . . . 3. Cyphelium.

A pothecia sessile; spores two-celled, dark, 4. Acolium. rhallus rigidly fruticose, termiual apothecia, 5. Spherophorus. 


\section{Coniocybe. ${ }^{1}$}

The representatives of this genus are few and insignificant; close examination is necessary to detect them. Usually, they occur upon the bark of trees in shaded places; less commonly upon decaying wood. The thallus is generally visible to the naked eye, and has a yellowish tinge. The apothecia and stipes are of a light color, never black; however, the color is quite variable, ranging from almost white to brownishgray and reddish-brown. The algx seem to belong to the genus Chroolepus and, therefore, occur in chains. The spores are spherical, small, simple, colorless, or faintly yellowish, with a distinct, irregular exosporium, which is readily removed, $7 \mu$ to $8 \mu .^{2}$

Coniocybe pallida is the only species which is likely to be found. Coniocybe furfuracea is usually sterile, that is, devoid of stipes and apothecia.

1. Coniocybe pallida. Thallus usually indistinct, whitish. Stipes comparatively long and slender, from nearly white to brown, bearing single globose apothecia of nearly the same color as the stipe. Spores simple, colorless, exosporium quite distinct, $7 \mu$ to $8 \mu$. On bark, New England (New Hampshire), Iowa.

2. Coniocybe furfuracea. Thallus quite distinct, of a sulphur color. Stipes, apothecia and spores as in C. pallida. On the exposed roots of trees and decaying wood, New England, New York. Sterile in Iowa.

1 The spores of all the genera mentioned are figured on Plates V to $\mathrm{XI}$ inclusive. The genera are given alphabetically.

${ }^{2}$ A $\mu$ or micron equals a thousandth of one millimeter or one twenty-five-thousandth of an inch. The measurements are made with the aid of an eye-piece micrometer. 


\section{Calicium.}

This genus is represented by a considerable number of species, which are uniformly insignificant plants, having no special interest for the amateur. In form they resemble Coniocybe. The stipes and apothecia are black, in other respects like those of Coniocybe. They occur upon tree trunks in shaded places, upon fences and decaying wood. The algæ are Protococus viridis; they occur singly, and are of a bright-green color. In some species the thallus is very deficient, or even wholly wanting, particularly in older specimens. Some species are included among fungi (Mucor) by various authors.

The spores are two-celled and dark.

1. Calicium Curtisii. Thallus wanting, or very rudimentary. Stipes dark, slender, bearing a single, dark, globose apothecium. Spores brown, two-celled, oblong, with pointed ends, $14 \mu \times 5 \mu$.

Occurs on tree-trunks, especially species of Rhus.

2. Calicium fuscipes. Thallus rarely recognizable. Stipes rather long and slender, dark-brown. Apothecia spherical, dark-brown; in fully matured plants the entire thecium may fall away. Spores dark-brown, elliptical, simple, $12 \mu \times 5.5 \mu$.

3. Calicium lenticulare. Thallus indistinct, colorless or whitish. Stipes rather short and thick. Apothecia comparatively large and somewhat flattened. Spores small, dark-brown, elliptical, simple, $6.5 \mu \times 4 \mu$.

4. Calicium hyperellum. Thallus only slightly developed, greenish-yellow, unevenly spreading. Stipes long, sleuder, dark-brown. Apothecia usually spheri- 
cal, dark-brown or rusty-brown. Spores brown, elliptical, two-celled, somewhat constricted in the middle, $10 \mu \times 6 \mu$.

5. Calicium quercinum. Thallus much as in $C$. hyperellum, less highly developed, not greenish-yellow. Stipe less slender, dark-brown. Apothecia usually spherical, dark-brown. The entire structure, including spores, resembling that of $C$. hyperellum. Spores brown, two-celled, constricted in the middle, $10 \mu \times 6 \mu$.

\section{Cyphelium.}

The representatives of this genus have the general characters of the Calicii. The apothecia are somewhat flattened and the spores are simple and dark, thus contrasting them with those of Coniocybe and Calicium, the exosporium is generally considerably thickened. In form they are usually spherical though they may be elliptical. The algæ are as in Calicium. In fact the amateur will perhaps place the specimens with the Calicii owing to their great similarity. They occur in the same localities as the other Caliciaceæ.

1. Cyphelium turbinatum. Thallus crustose, well developed. Stipe very short, projecting slightly above the lobes of the thallus. Apothecium much as in the foregoing, dark-brown, entirely closed at first, later opening by Cep-segment. Spores small, dark brown, spherical, simple, exine considerably thickened, $7.5 \mu \times 6.5 \mu$.

2. Cyphelium tubceforme. Thallus occurs almost entirely under the bark, fairly developed. Stipe 
rather short, of medium thickness, dark. Apothecia somewhat flattened, dark. Spores rather large, simple, dark-brown; usually spherical; some slightly elongated with pointed tips, exine distinct, $12 \mu \times 20 \mu$.

\section{Acolium.}

This genus is undoubtedly closely related to Calicium. The thallus is well developed and of a marked green color in $A$. tigillare. The stipe is much reduced, so that the apothecium is sessile or immersed in the thallus. The thallus encloses the apothecium in a crater-like fashion, showing the dark epithecium at the top. The spores are two-celled and dark. The algæ are as in Calicium.

'There are only two species reported in the United States, of which A. tigillare is quite common. Its natural substratum seems to be old pine fence-boards, upon which it occurs in patches of considerable extent. From its position it is evident that it has the ability to resist greater extremes of dryness than the majority of lichens. It occurs quite frequently on fenceboards in prairie farm-yards which are comparatively little shaded.

1. Acolium tigillare. Thallus distinctly crustose and minutely areolate, yellowish-green. Apothecia numerous; the very short stipes, as well as the greater portion of the apothecium, are enclosed by the thallus, producing conical elevations. Epithecium dark. Spores two-celled, somewhat constricted at the middle, thick, dark spore-wall, $10 \mu \times 14 \mu$. 


\section{Spharophorus.}

This genus represents the highest development of the Caliciacex, there is a wide gap between it and Acolium. The links are entirely wanting in the United States. It has been questioned whether Sphærophorus belongs to the Caliciacex; concerning this there can, however, be no doubt. The apothecia and spore characters are the same as those of the other genera.

The thallus is fruticose, quite large, of a rigid cartilaginous consistency; color brown or reddish-brown. The apothecia are globose and terminal on the branches of the thallus; they open by terminal chinks, thus setting free the simple dark spores. The spores are characterized by the irregular dark blue exine (exosporium) which is readily removed.

1. Spharophorus fragilis. Thallus-lobes cylindrical, smooth, color somewhat variable, from light gray, brownish to dark, dichotomously branching, ends of branches usually with numerous short lobes, tips blunt or rounded. Usually sterile or apothecia few, shrunken. Disk black. Entire apothecium easily removed at the hypothecial zone. Spores elliptical, simple, dark-brown exine, $15 \mu \times 10 \mu$.

2. Spharophorus globiferous. Thallus lobes cylindrical, variable in length, usually of uniform brown color, especially in old herbarium material. Branching dichotomous. Apothecia globoid, opening by chinks or pores. Spores spherical, simple, blue-black exine easily removed by pressure, $12 \mu \times 14 \mu$. 


\section{CLADONIACEAE.}

The representatives of this family are quite common everywhere, occurring chiefly upon soil or rocky ledges; less commonly upon old fences, tree-trunks and rotten wood. They are conspicuous as to size. The thallus is peculiar in that it is made up of two parts: one erect (secondary thallus or podetium, hence fruticose), varies from simple to much branched; the other portion (primary thallus), spreading over the substratum, varies from crustose (Baomyces) to foliose ( $C l a-$ donia). Strictly speaking, the upright portion of Baomyces is only a stipe, as in the preceding family.

The apothecia are distinct and occur in all the genera excepting Thamnolia, which is always sterile. They are more or less globose, disk convex to flattened but never cup-shaped. No alga occur in any part of the apothecia; for that reason they beloug to the fungal type. (See Figs. 1 and 2, Plate IV.)

\section{KEY TO THE GENERA.}

Thallus (primary) crustose or warty.

Apothecia borne on unbranched thick stipes or nearly sessile . . . . . . . . 1. Bromyces.

Apothecia terminal on the erect thallus (podetia).

Frect thallus hollow, spores simple . 2. Pilophoron.

Erect thallus solid, spores four-celled . 3. Stereocaulon. Thallus (primary) foliose or wanting, erect thallus hollow.

Apothecia usually present, disk brown or red,

4. Cladonia.

Apothecia always wanting, erect thallus tapering,

\section{Baomyces.}

5. Thamnolia.

The representatives of this genus usually occur upon loamy or sandy soil in forest lands. The primary thallus is usually crustose; in some of the Southern 
forms it, however, becomes almost foliose. The name Baomyces means a "small fungus," or "toadstool." The light color of the stipes and apothecia do give it a marked resemblance to the fungi of the mushroom or toadstool order. The stipes are never branching, and are almost entirely wanting in one species. The apothecia are well developed and vary from globose to distinctly flattened. The algæ are light-green, singlecelled, belonging to Protococcus. A Glococapsa also occurs with some species (B. roseus). Spores are colorless, spindle-shaped to almost acicular, simple or very indistinctly septate.

None of the species have been credited with any special virtues.

The collector will meet with these plants in forest lands, where they occur in patches, usually several feet (sometimes less) in diameter. B. roseus is most common, and is characterized by a greenish-gray crustose thallus, which is in marked contrast with the soil. Care is necessary to preserve the specimen. Place the lichens, attached to a considerable portion of the soil, in a suitable pasteboard box, or wrap carefully in paper. They had best be kept in paper pockets or in small pasteboard boxes, as indicated.

1. Bøomyces roseus. Thallus granulose, greenish. Stipes comparatively long, white or a faint rosy tint. Apothecia, spherical (both stipe and apothecium collapse on drying). Disk a rosy tint. Spores in long slender sacs, acicular, usually slightly curved, sometimes faintly septate, colorless, $25.5 \mu \times 3.5 \mu$. 
2. Baomyces aruginosus. Thallus evenly spread1ng, with rather large granules, gray-green. Stipes very short or none. Apothecia quite flat, yellowish disk. Spore-sacs long, cylindrical ; spores oblong, colorless, usually distinctly uniseptate, $17 \mu \times 8 \mu$, rather variable in size and form.

3. Bromyces byssoides. Thallus granulose, with elevated, flattened squamules. Stipes longer than in aruginosus, flattened above. Apothecia flattened. Disk reddish-brown. Spores simple, colorless, elliptical, $10 \mu \times 4 \mu$.

\section{Pilophoron.}

This genus is represented by one well-marked species, which is of rare occurrence. It seems to be somewhat northern in its range, preferring moist, shaded places.

The primary thallus is deficient, warty, greenishgray. The vertical thallus (secondary thallus, or podetium) consists of an erect stem, which may be once, or very rarely twice, branched toward the top. Upon examining a transverse section it is found that this stem is hollow (lumen is narrow, however), and that it contains algie (Protococcus), thus being essentially different from the stipe of Baomyces.

The apothecia are terminal, globose, black or blueblack. The spores are simple, oblong to spindleshaped, colorless.

1. Pilophoron cereolus. Primary thallus granular, greenish to gray; podetia, from medium to long and slender, simple, or once or twice branched above, granular, greenish to gray. Apothecia comparatively large 
and numerous, nearly spherical. Thecium of a blueblack tint near the top. Disk blue-black, smooth. Spores simple, elongated, colorless, $25.5 \mu \times 7 \mu$.

\section{Stereocaulon.}

The most marked morphological character of this genus is the comparatively large fruticose thallus; it consists of numerous crooked and somewhat flattened branches, which are covered by warty thalloid outgrowths. Upon careful examination numerous darkblue cephalodia will be found on different parts of the branches. The color of the thallus is generally ashgray.

The primary thallus is deficient, so much so that the average collector will take no notice of it whatever. The secondary thallus is not hollow, as in the foregoing genus When dry, the Stereocaulons are very brittle. They occur most commonly upon rocky ledges in hilly and mountainous regions. They are somewhat northern in their range.

The apothecia are terminal, medium size, globose or flattened, dark-brown to nearly black. The spores are colorless, spindle-shaped, usually four-celled. The following are the more common species:

1. Stereocaulon condensatum. Primary thallus distinct, granular and warty, green to dark-gray. Podetia short, branched, covered with thalloid warts resembling those of the primary thallus. Apothecia rather large, simple or confluent. Disk convex, darkbrown. Spores acicular, triseptate, colorless, $25 \mu$ $\times 2.5 \mu$. 
2. Stereocaulon coralloides. Primary thallus coarsely granular or warty in young plants, grayish-white, usually wanting in fully developed plants. Podetia rather long and slender, more or less compressed, much branched, profusely covered with coarsely granular or warty outgrowths, light-gray to rather dark (cephalodia common). Apothecia medium, nearly spherical, often wanting. Disk brown to black. Spores colorless, triseptate, elongated, ends pointed, $27 \mu \times 6 \mu$.

3. Stereocaulon denudatum. Primary thallus granular and irregularly globular, usually wanting. Podetia much as in $S$. coralloides, thalloid warts more or less confluent, sometimes flattened, greenish to gray; lower, hence older, portions of branches quite bare (free from thalloid warts), and of a brownish color. Apothecia and spores as in S. coralloides.

4. Stereocuulon ramulosum. Primary thallus of flattened squamules, with crenate margins usually wanting. Podetia usually long, otherwise, as in $S$, coralloides, covered with flattened thalloid warts, with crenate margins. Apothecia from small to large, simple, confluent to flattened. Disk, dark-brown or black. Spores as in $S$. coralloides.

5. Stereocaulon paschale. Primary thallus granular, usually wanting. Podetia long, much branched, covered with minutely branching outgrowths. Apothecia and spores as in $S$. coralloides.

Species 2, 3, 4 and 5 are in many respects closely similar; so much so that it seems probable that they are mere variations of one species. Further careful observation and study are necessary to prove whether or 
not this be true. S. paschale is a typical rock-lichen. It is said to be the first plant to develop upon the volcanic lava of Vesuvius and Ischia. In various parts of Europe wild animals feed upon it. In Lapland the reindeer often feed upon it when Cladonia rangiferina is scarce.

\section{Cladonia.}

This genus is represented by a great number of species which are so variable and diversified in form that the systematist has considerable difficulty in defining their limitations and describing them clearly. It is, however, fortunate that nearly all of the representatives are readily recognized as belonging to Cladonia. A few species are also quite characteristic as to form and once seen are not likely to be forgotten or mistaken for any other species; such are $C$. rangiferina, C. papillaria, C. pyxidata, C. cariosa, and a few others.

Excepting in C.papillaria, the primary thallus is foliose, although the individual thalli are minute; sometimes simple and entire, again considerably lobed or even distinctly branching. Usually a large number of thalli occur together, more or less imbricate with one side elevated. The upper surface is distinctly bright-green, the lower surface whitish. The vertical thallus (secondary thallus, podetium) is very variable in form; from simple to much branched. The simple forms, again, vary as to size and structure; some are nearly smooth, while others bear numerous leafy outgrowths resembling the primary thalli; some are cup-like toward the apex, 
while others have several of these cup-like or discoid expansions at regular intervals. The branching forms also vary greatly as to size, manner of branching, etc. The color varies somewhat; greenish-gray, however, prevails. The podetia are hollow, and exemplify a mechanical type especially adapted to resist lateral forces (air currents).

The apothecia are terminal upon the podetial branches, or short apothecial stalks borne upon the margin of the cup-shaped or discoid expansions. They are usually simple or more or less confluent, globose, either brown or bright-scarlet. The scarlet apothecia at once prove the specimen a species of Cladonia. 'The spores are simple, elliptical, colorless, and vary little in the different species. It must also be remembered that some of the higher Cladonias are constantly sterile.

The Cladonias are widely distributed; they occur upon soil and rock, less commonly upon tree-trunks and fences. They are northern in their range.

1. Cladonia papillaria. Primary thallus crustose to warty. Podetia (secondary thalli) short, smooth, club-shaped, somewhat tapering near the apex. Apothecia rare in some localities, small, more or less confluent. Disk convex, brown. Spores simple, elliptical, colorless. ${ }^{\mathbf{1}}$

This species is quite common on soil in the hilly districts of New Jersey and eastern Pennsylvania.

1 The spores of the Cladonias are so closely similar that the measurements and special descriptions will be oinitted in most instances. The average measurements are 14 microns in length by 4
microns in width. 
Formerly it was classified with another genus (Pycnothelia), which is not at all surprising because it certainly has few characters in common with most Cladonias.

2. Cladonia delicata. Primary thallus consists of numerous medium sized, closely crowded lobes, which are sometimes finely branched. Podetia short, slender, sometimes branching above. Apothecia medium, confluent. Disk convex, brown. Spores rather small.

8. Cladonia caspiticia. Primary thallus well developed, much cleft or irregularly branching. Podetia very short or wanting. Apothecia medium. Disk convex, brown. Spores comparatively numerous and a little above the average in size.

4. Cladonia symphycarpa. Primary thalli well developed, usually rounded, sometimes elongated, branching inconspicuous, upper surface generally convex. Podetia short, rather thick, slightly branching. Apothecia well developed. Disk convex, confluent, dark-brown. Spores rather large, $15 \mu \times 3.5 \mu$.

5. Cladonia mitrula. Primary thalli usually small, numerous, rounded, almost entire, sometimes much enlarged and branching. Podetia from short to medium, entire or rarely branching near the apex. Apothecia medium to large, usually confluent. Disk convex, brown. Spores numerous.

6. Cladonia pulchella. Primary thallus well developed; lobes branched, elongated, slender. Podetia somewhat elongated, branched toward the apex, bear- 
ing thalloid outgrowths. Apothecia rather large, usually confluent. Disk convex, scarlet. Spores normal in size and form.

7. Cladonia cariosa. Primary thallus usually well developed; lobes from small and simple to large and irregularly branching, with crenate margiu. Podetia of medium length, expanded and irregularly branching above, warty. Apothecia numerous, rather large. Disk convex, brown. Spores colorless, elliptical, simple, $12 \mu \times 3.5 \mu$.

8. Cladonia decorticata. Primary - thallus fairly well developed; lobes usually small and almost entire, sometimes large and much branched, margin crenate. Podetia medium to long, branched above, finely granular and sometimes bearing thalloid outgrowths, but soon becoming decorticate, beginning at the base. Apothecia very numerous, medium size, confluent. Disk convex, brown. Spores rare.

9. Cladonia macilenta. Lobes of primary thallus scattered over substratum, variable in size and branching; margins distinctly crenate. Podetia medium, slender to rather thick, covered by scaly thalli which dis"appear after a time. Apothecia medium to large, confluent. Disk convex, scarlet. Spores normal.

10. Cladonia cristatella. Primary thallus fairly well developed; lobes from small and almost entire to large and branching, usually more or less adnate. Podetia medium, branched above, rarely simple, granular, bearing secondary thalli. Apothecia very numerous, medium size, confluent. Disk convex, scarlet. Spores rare. 
11. Cladonia cenotea. Primary thallus usually absent; when present, large, elongated and much branched. Podetia rather long and thick, branched near the top, lower portion often bearing thalloid lobules. Apothecia rare. Disk flesh-colored to darkbrown. Spores usually wanting.

12. Cladonia alcicornis. Primary thallus well developed, much elongated, branched, margin crenate. Podetia not very numerous, often wanting, medium height and thickness, much expanded above, either cupshaped or leaf-like, bearing a few usually large thalloid lobules. Apothecia sessile or on short stalks, rather small. Disk convex, light-brown to reddish-brown.

13. Cladonia lepidota. Primary thallus of much elongated and divided lobes. Podetia medium, sparingly branched toward the base; much branched near the apex, bearing many thalloid lobules. Apothecia often wanting.

14. Cladonia pyxidata. Primary thallus well developed; lobes rather large, broad, and indistinctly branched. Podetia from short to medium in length, from medium to very thick, much expanded above, not branching, scaly, sometimes bearing a few thalloid lobules. Apothecia rare, on short stalks, small. Disk convex, somewhat confluent, brown.

Lindsay says of this lichen, "It is the 'cup-moss' of the London herbalists. It contains a considerable quantity of gummy or starchy matter, and has been much used as a demulcent in various chest affections." Its medicinal uses, which have been most varied, have resembled those of Cetraria Islandica. 
15. Cladonia deformis. Primary thallus sparingly present or wanting. Podetia from medium to long, very rarely bearing thalloid lobules, rather thick, terminating in a cup which becomes degenerate and indistinct with age. Apothecia on secondary branches of considerable length, which grow from the margin of the cup ; rather large, confluent. Disk convex, scarlet.

16. Cladonia bellidiflora. Primary thallus fairly well developed. Lobes rather large, irregularly branching. Podetia long, thick to very thick, rarely branching, usually covered with thalloid lobules. Apothecia large, irregular in outline. Disk a bright-scarlet. Spores $13.5 \mu \times 3.5 \mu$.

17. Cladonia cornucopioides. Primary thalluslobes irregularly scattering, rather long, branching. Podetia of medium length, rather thick, expanded, trumpet-shaped above, covered by minute scaly warts. Apothecia on short stalks growing from the edge of the expanded portion; entire, orbicular to elongated, variable in size and form. Disk bright-scarlet. Spores $10 \mu \times 2.5 \mu$.

"This is probably the 'red cup-moss' of which Mrs. Hemans sings in the following stanza:

"'Oh! green is the turf where my brothers play Through the long bright hours of the summer day ; They find the red cup-moss where they climb, And they chase the bee o'er the scented thyme.'

"It occurs in the antarctic regions and is otherwise somewhat widely distributed. It appears to contain a small quantity of gummy and starchy matter; hence 
it has been used, boiled in milk or syrup, in whoopingcough and other chest affections in children. In Thuringia, a decoction has been used in the treatment of intermittent fevers." - Lindsay.

18. Cladonia digitata. Primary thallus large, rarely branching, minutely lobed with crenate margin. Podetia medium in length, from slender to thick, expanded into an irregular cup with incurved margin ; secondary branches show a palmate, one-sided development from the margin of the cup, that is, some of the secondary branches remain rudimentary. Apothecia usually borne on secondary branches, rarely on short stalks; confluent. Disk convex or slightly concave, scarlet.

19. Cladonia gracilis. Primary thallus of rather large scattering lobes, branching usually once or twice. Podetia long, slender, variable, sometimes simple and pointed, again more or less branching, sometimes bearing rather small cups from which one or more branches of considerable size develop. Apothecia medium, on short stalks. Disk convex, brown.

20. Cladonia fimbriata. Primary thallus rather large, more or less scattered, usually once or twice divided, margin crenate. Podetia usually long, slender, sparsely branched, sometimes terminating in a cup, attenuately pointed, rarely bearing thalloid lobules, white, smooth or granular, becoming decorticate. Apothecia terminal on small branches from the margin of the cups, medium, confluent. Disk convex, brown.

21. Cladonia verticillata. Primary thalli sparingly present. Lobes from small to medium, more or less orbicular, scattering. Podetia from medium to very 
long, rather slender, expanded, cup-like, bearing here and there a few thalloid lobules, branches sometimes formed on the cups or the margins of the cups. Apothecia usually rare, on short stalks from the margins of the cups, small to medium. Disk convex, brown.

22. Cladonia squamosa. Primary thallus well developed, slender, elongated, variable in size and frequency of branching. Podetia rather long and slender, irregularly branched, branches decreasing in length and thickness directly with the number of divisions, bearing many thalloid lobules. Apothecia rather small. Disk convex, brown. Spores comparatively numerous, $12 \mu \times 3.5 \mu$.

23. Cladonia turgida. Primary thallus large, elongated, branched. Podetia long, rather thick, irregularly branched, sometimes perforate. Apothecia rare, small, hemispherical, on short slender branches. Disk light reddish-brown. Spores very rare.

24. Cladonia uncialis. Primary thallus deficient or wanting. Podetia in dense clusters, much expanded, branching, more or less perforate, terminal branches pointed, usually sterile. "Podetia incrassated above, cymose, brown."

25. Cladonia furcata. Primary thallus consisting of a few small scattering lobes, sometimes becoming large, and indistinctly branched. Podetia long, rather slender, frequently branched (thickness and length of branches decreasing with the number of divisions), smooth, whitish, bearing thalloid lobules. Apothecia from small to medium. Disk convex, brown. Spores rather large (long). 
26. Cladonia leporina. Primary thallus rare. Lobes narrow and much branched, quite rigid. Podetia rather long, distinctly and uniformly twice branched, quite smooth. Apothecia small. Disk convex, scarlet.

27. Cladonia amaurocraa. Primary thallus deficient or wanting. Podetia long, slender, much branched, terminal branches not bearing spermagonia are pointed. Apothecia rather small. Disk flat or slightly concave, margin and a central portion often somewhat elevated, reddish-brown. Spores $10 \mu \times 4.5 \mu$.

28. Cladonia rangiferina. Primary thallus often wanting. Podetia long and rather slender, frequently branching, smooth, greenish to ash-gray, terminal branches short, somewhat recurved. Apothecia are frequently wanting, small, simple. Disk convex, brown.

"Crabbe calls it truly,

"'The wiry moss that whitens all the hill.'

"'Omnium lichenum copiosissima,' according to Fries, - it is almost a cosmopolite, but its geographical range is, in various parts of the world, very irregular and limited. In Northern Europe it is used, like Certaria Islandica, as a nutrient and demulcent. It is a social plant, covering in Lapland vast tracts of country, and growing to a height of six to twelve inches. The barren plains so covered are the favorite and only pasture of the reindeer during winter; the animals clear away the snow by means of their 
horns to browse on the lichen. It is also frequently collected, like hay, as fodder for cattle during winter and for the reindeer on journeys. Parry, in the narrative of his fourth voyage, mentions his officers collecting supplies of this lichen as provender for the reindeer, which he used in the capacity of horses; he adds, 'It required a great deal of picking' to separate it from the moss, among which it usually grows. The daily quantity of cleaned ' reiudeer moss' - as it is popularly denominated - necessary for each animal on a journey is four pounds; but, he remarks, it can easily remain for five or six days without food. To prepare it as fodder for cattle, in some northern countries, hot water is poured over it; it is then mixed with straw, and a little salt sprinkled over the mixture. Cattle so fed are said to produce delicious milk and butter, while their flesh becomes fat and sweet. Bucke, in his ' Harmonies of Nature,' speaks of small cows, by feeding on this lichen, whose milk becomes wholly cream. The stag, deer, roebuck and other wild animals also feed on it abundantly during winter. But it is not only serviceable as food to the lower animals, - man himself is frequently compelled to use it in times of scarcity. It is sometimes powdered, mixed with flour and baked into bread; or it is boiled in milk or broth. Clarke, in his 'Travels,' mentions having eaten it, and even speaks of it in a commendatory way. It is sold by the London herbalists for the purposes of the bird-stuffer. In a pulverized state it at one time formed a frequent ingredient in hair-powders and perfumes." - Lindsay. 


\section{Thamnolia.}

This genus is represented by one species only. It is quite probable that it belongs to Cladonia ; in fact, that is the position given it by many lichenologists.

The primary thallus is wanting. The podetia are quite free from warts or excrescences, hollow, simple or sparingly branched. They are widest at the bottom, gradually tapering upward, a character not occurring in the simpler podetia of Cladonia. Color varies from greenish-gray to pale straw-color.

No apothecia have been found; it is propagated by means of soredia, and also vegetatively.

It occurs upon rock and soil in the ligher altitudes and latitudes.

1. Thamnolia vermicularis. Primary thallus wanting. Podetia rather long, usually simple, sometimes one or more short branches toward the apex, thin, tapering, sometimes wrinkled longitudinally, color as above. No apothecia, and hence no spores.

\section{LECIDEACEAE.}

Stipes and podetia are wholly wanting in this family, which distinguishes it from the preceding families. The apothecia are sessile upon the thallus, discoid, and belong to the fungal type. The disk is generally convex or flattened. The thallus varies from crustose to distinctly foliose, never fruticose. The foliose thalli are entire, not distinctly lobed or branched.

It must be stated that considerable doubt exists as to the exact limitations of this family. Some of the 
lower genera here included present widely different spore-characters, which would perhaps indicate a remoter relationship than is assumed. In some instances the thallus is very rudimentary. Because of the absence of well-marked family-characters, the amateur is likely to confuse some of the lower genera with the lower genera of the Parmeliacea, and perhaps some Verrucariacea, to be considered later.

\section{KEY TO THE GENERA.}

Thallus indistinctly crustose to warty.

Spore-sacs bearing sixteen simple colorless spores,

Spore-sacs bearing eight spores (usual number)

1. Biatorella.

Hypothecium and spores colorless.

Spores elliptical.

Two-celled .

Simple

Four-celled

Spores acicular, six to eight-celled

Hypothecium dark.

Spores colorless.

Simple

Two-celled * . • • • 6. Lecidea.

Four-elled. . . . . \%. Catillaria.

Spores dark.

8. Celidiopsis.

Two-celled.

Four-celled $\cdot$ 10. Bueliopsis.

2. Biatorina.

3. Biatora.

4. Bilimbia.

5. Bacidia.

Spore-sacs bearing from one to six spores, hypothecium colorless or yellowish.

Spores simple, colorless, large . . 11. Megalospora,

Spores multilocular. ${ }^{1}$

Dark. . . . . . . . 12. Lopadium.

Thallus foliose, entire.

Colorless . . . . . . 13. Gyalecta.

Small, adnate to substratum, spores simple, colorless,

Large, umbilicate; apothecia black, sessile.

Spores simple, colorless. . . . 15. Gyrophora.

Spores multilocular, large : . : 16. Úmbilicaria. 1 By "multilocular spores" is meant many celled spores having
"epta formed in two planęs of thespore. 


\section{Biatorella.}

A very insignificant group; only one species has come to my notice. The thallus is very rudimentary or entirely wanting; repeated search is necessary to detect the algæ (Protococcus). The apothecia are small, dark and considerably scattered, which adds to the difficulty of finding specimens. The spores are simple, small and colorless, sixteen usually occurring in each spore-sac.

The Biatorellas seem to prefer sterile soil.

1. Biatorella geophana. Thallus deficient or wanting. Apothecia small. Disk convex, dark-brown. Spores simple, nearly spherical, colorless, $8 \mu \times 7 \mu$.

\section{Biatorina.}

This genus is likewise deficient in representatives. The thallus is rudimentary but readily recognizable; it is usually greenish in color and uniformly crustose, never becoming warty or areolate. The algæ are bright-green, occurring in chains of rather small cells (Chroolepus umbrina). The apothecia are quite small. Disk flattened or slightly concave, brown or even pale-brown. Some authors combine this group with Biatora; but the elliptical, colorless, two-celled spores exclude it. They occur upon soil, tree-trunks and moss.

1. Biatorina lutea. Thallus thin, evenly spreading, somewhat granular, light-gray to greenish. Apothecia rather small, discoid. Disk of a yellowish waxy color. Spores colorless, elliptical, two-celled, $15 \mu \times 5 \mu$. 
2. Biatorina pineti. Thallus very rudimentary, dark. Apothecia very small. Disk dark. Spores as in B. lutea.

$B$. lutea occurs upon moss, while $B$. pineti occurs upon pine trees. Both are quite rare.

\section{Biatora.}

This genus is represented by a considerable number of species. Some authors have made it the dumping ground for many lichens which have no evident affinity to the typical representatives. Thus, for example, Biatorella, Biatorina, Bilimbia, Bacidia, Psora, Acarospora, etc., have been included in Biatora, and are yet so included by some recent authors. This is no doubt primarily due to insufficient attention to spore-differences.

The thallus varies from typically crustose to warty and minutely foliose. The color tends toward grayish-green. The algæ are Protococcus (Cystococcus).

The apothecia are of medium size, discoid. Disk flattened to convex, light-brown to dark and black. The hypothecium is colorless. Spores are elliptical, simple, colorless.

The Biatoras are widely distributed, and occur upon bark, less commonly upon rock and moss. They are active in the disintegration of rock, but much less so than their near relatives, the Lecideas.

The following are the more common species.

1. Biatora varians. Thallus thin, granular, grayish-green; margin dark. Apothecia small, sessile, 
irregular margin. Disk yellowish to brown. Spores ovoid or nearly spherical, colorless, $7 \mu$ to $10 \mu$.

This species has many characters peculiar to the lower Lecanoras, which would make it seem proper to place it with that group.

2. Biatora myriocarpoides. Thallus thinly crustose and of a dark muddy color. Apothecia small, sessile. Disk flat or slightly convex, dark. Spores elliptical, colorless, $8.5 \mu$ to $9 \mu$.

The hypothecium is generally dark or even black, which would point toward the Lecideas; but the color variations of the hypothecium are, however, too great to be reliable as a generic character.

3. Biatora uliginosa. Thallus consists of minute granular elevations, color varies from gray to dark or black. Apothecia small, few in number. Disk flattened, sometimes convex, dark color. Spores elliptical, colorless, rarely two-celled, $22 \mu \times 8 \mu$.

4. Biatora contigua. Thallus evenly spreading, scaly or squamose, light-gray. Apothecia comparatively large, numerous, sessile. Disk convex, sometimes flattened, black with a translucent white film which is characteristic of the species. Spores elliptical, colorless, $22 \mu \times 8 \mu$.

5. Biatora diapensia. Thallus rudimentary, color whitish. Apothecia of medium size. Disk generally convex, reddish-brown or black. Spores colorless, elliptical, $10 \mu \times 3.5 \mu$.

The hypothecium is occasionally black, and this plant may, therefore, be mistaken for a species of Lecidea. 
6. Biatora vernalis. Thallus thin, granular, gray to greenish. Apothecia variable in size, sometimes in clusters. Disk yellowish to tawny, sometimes black. Spores elliptical to oblong, often indistinctly two-celled, colorless, $15 \mu \times 7 \mu$.

7. Biatora russula. Thallus granular, ash-gray to greenish. Apothecia small to medium. Disk flat or convex, brick-red. Spores colorless, oblong, sometimes indistinctly two-celled, $11 \mu \times 8.5 \mu$.

8. Biatora peliaspis. Thallus indistinct, dark-brown to black. Apothecia medium size. Disk varying from grayish to black. Spores variable in size and form, simple, colorless, averaging $10 \mu \times 4.5 \mu$.

The hypothecium is often brown to dark in color, perhaps never entirely black.

9. Biatora parvifolia. Thallus usually distinct, minutely thalloid or scaly, pale-green to yellowishgreen or even reddish-brown. Spores oblong, colorless, simple, $14 \mu$ by $4 \mu$.

As the name (parvifolia) indicates, this is in reality a foliose lichen, but the lobes are so insignificant that the average collector will take it for a crustose lichen.

10. Biatora granulosa. Thallus distinct, of grayish-white, smooth wart-like elevations which often bear greenish soralia. ${ }^{1}$ Apothecia of medium size. Disk convex, usually black, sometimes dark-brown or reddish. Spores variable in size and form, simple, colorless or faintly yellowish-brown, $16 \mu \times 7 \mu$.

11. Biatora cinnabarina. Thallus granular, con-

1 Soralia are aggregates of soredia which may occur as circular or linear patches. The word was introduced by Reinke (1895). 
sisting of numerous minute but distinct elevated granules, whitish to yellowish-green. Apothecia medium size. Disk convex, bright-scarlet. Spores oblong, often somewhat larger at one end, simple, colorless. $24 \mu \times 4 \mu$.

This species does not occur in the northeastern United States. It is western aud southern in its range.

\section{Bilimbia.}

This is another insignificant group represented by only a few species. Its general characters correspond to those of the Biatoras and Lecideas. Various authors include it under Biatora.

The thallus is crustose, never becoming foliose as in some of the Biatoras. The apothecia are of medium size. Disk flattened or convex, color yellowish-brown to dark-brown. The algæ are in all probability Protococcus, but differ from the usual forms in their small size. Spores are spindle-shaped, colorless, usually four-celled.

The Bilimbias occur upon tree-trunks and moss.

1. Bilimbia mixta. Thallus granular, warty, whitish, or faintly yellow. Apothecia small, adnate. Disk convex, usually black. Spores oblong, two to fourcelled, colorless, sometimes slightly curved, $18 \mu \times 5 \mu$.

2. Bilimbia hypnophila. Thallus granular, spreading, greenish to gray. Apothecia small, sessile, unevenly convex. Disk black, thecium and hypothecium reddish-brown. Spores as in B. mixta.

3. Bilimbia spharoides. Thallus distinct, uniformly spreading, granular, greenish. Apothecia nearly glo- 
bose, attached by a narrow neck. Disk yellowish or tawny. Spores as in B. mixta.

\section{Bacidia.}

This genus is represented by a considerable number of species and is well characterized, although some authors include it under Biatora, no loubt because in its gross characters it resembles that genus.

The thallus is typically crustose, sometimes becom. ing indistinctly areolate or coarsely granular, color gray to greenish. The alga are Protococus. The apothecia are of medium size. Disk convex to flattened, light-brown to black; the hypothecium varies from dark-brown to nearly black. 'The spores are much elongated, acicular, more narrow toward one end, colorless, five to eleven-celled, variable in size and form.

This genus is southern in its range. They generally occur upon tree-trunks, more rarely upon rock and moss.

1. Bacidia albescens. Thallus thinly granular, greenish to gray. Apothecia small. Disk convex, pale-yellowish or pale-brown. Spores very slender, indistinctly septate, $35 \mu \times 1.8 \mu$.

2. Bacidia cuprea-rosella. Thallus granular to squamose, light-gray to greenish-gray. Apothecia small. Disk convex, yellowish to reddish-brown. Spores comparatively short and thick, usually blunt at both curls, five-celled, colorless, $17 \mu \times 3 \mu$.

3. Bacidia chlorosticta. Thallus deficient, minutely granular, gray to greenish. Apothecia very small. 
Disk convex, black. Spores small, slender, more or less curved, five to seven-celled, colorless, $20 \mu \times 1.5 \mu$.

4. Bacidia atrogrisea. Thallus granular, greenish to gray. Apothecia rather small. Disk convex, black. Spores nine to eleven-celled, pointed at both ends, variable in length and width, colorless, $60 \mu$ $\times 5 \mu$.

5. Bacidia inundata. Thallus granular, or more or less squamose, greenish to gray. Apothecia small. Disk convex, brown to black. Spores seven to ninecelled, indistinctly septate, colorless, $31 \mu \times 2 \mu$.

6. Bacidia rubella. Thallus of distinct, more or less scattered granules, greenish to gray. Apothecia of medium size. Disk reddish-brown to dark-brown. Spores colorless, nine to eleven-septate, $50 \mu \times 4 \mu$.

7. Bacidia suffusca. Thallus thinly granular, greenish to ash-gray. Apothecia of medium size to quite large, raised margin. Disk reddish-brown coated with a translucent whitish film, giving it a characteristic appearance. Spores seven to nine-celled, colorless, $50 \mu \times 4 \mu$.

8. Bacidia Schweinitzii. Thallus granular, forming a thin crust, greenish to ash-gray. Apothecia of medium size. Disk brown to black. Spores colorless, seven to nine-celled, $55 \mu \times 4 \mu$.

\section{Lecidea.}

The representatives of this genus resemble the Biatoras very closely, so much so in fact that it would seem advisable to combine the genera. The only essential difference seems to be the greater pre- 


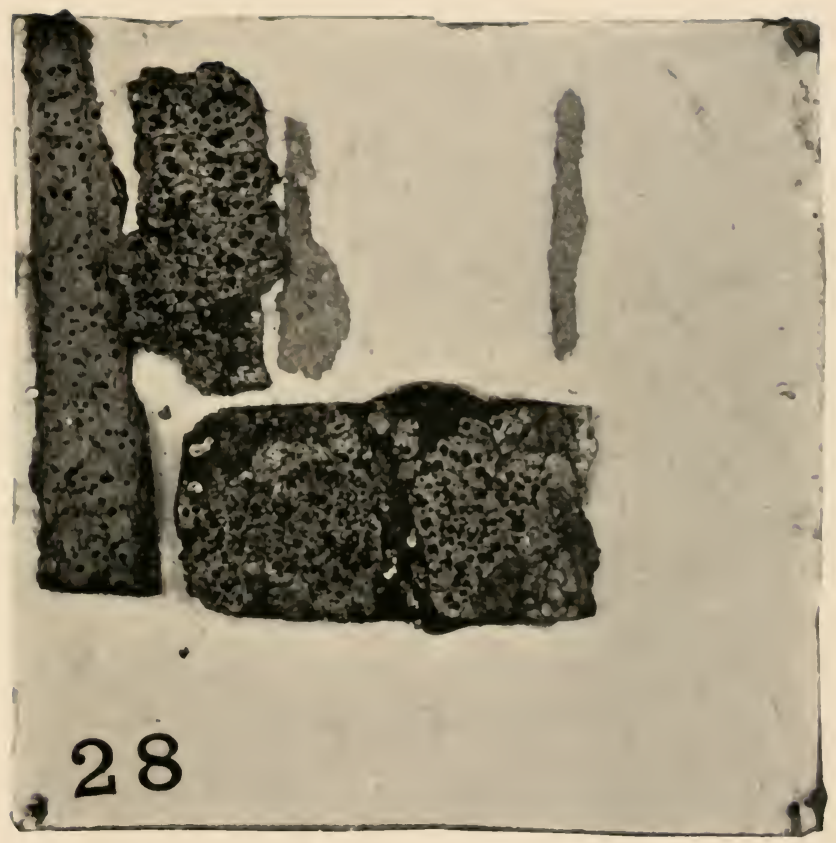

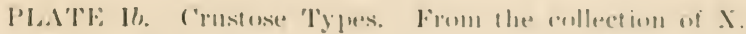

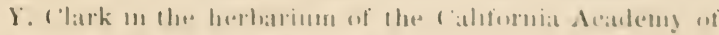

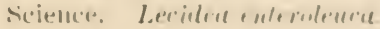



dominance of dark coloration in the Lecideas, especially in the disk and hypothecium. The Lecideas are also more brittle. As in Biatora, the spores are simple, elliptical and colorless.

The majority of the species occur upon rock, some upon trees and fences. They play a very important part in the disintegration of rock.

The Lecideas have the widest range of distribution: they occur at all latitudes and altitudes. Lecidea geographica occurs far above the line of perpetual snow; it forms the last vegetation of the Andes, the Himalayas and the arid peaks of Nova Zembla.

1. Lecidea pancola. Thallus consists of rather thick, closely crowded squamules, which are convex above and of irregular outline; ash-gray to dirty brown. Apothecia comparatively large; sometimes two or three are united. Disk convex, dark-brown to black. Spores simple, colorless, elliptical, $14 \mu \times 4.5 \mu$.

2. Lecidea enteroleuca. Thallus granulose to indistinctly squamose, ash-gray to greenish. Apothecia small to medium. Disk flattened, margin somewhat raised, black. Spores simple, colorless, elliptical, $12 \mu \times 6 \mu$.

3. Lecidea melancheima. Thallus coarsely granular, rugose or warty, gray or greenish-white. Apothecia of medium size. Disk convex, black. Hypothecium yellowish or faintly brown. Spores colorless, simple, elliptical, $9 \mu \times 3.5 \mu$.

4. Lecidea geographica. Thallus areolate, alternately dark and yellow, producing a characterisic effect faintly resembling a colored map. Apothecia 
rather small, somewhat immersed, flattened. Disk dark. Spores simple, colorless, elliptical.

\section{Celidiopsis.}

Another insignificant group having a close resemblance to Bilimbia and by some authors placed with Biatora. It differs from Bilimbia in that the hypothecium is dark. The genus requires further careful study. Only a few species are reported. 'These occur upon tree-trunks and moss.

1. Celidiopsis platycarpa. Thallus rudimentary, granular, gray to greenish. Apothecia small, elevated margin. Disk flattened, black. Spores colorless, rather variable in size and form, four-celled, $22 \mu \times 5 \mu$.

\section{Buelliopsis.}

This genus is represented by a few species. It differs from Buellia in its spore-characters, otherwise it is the same. The spores are four-celled, dark, constricted at the transverse septa.

1. Buelliopsis vernicoma. Thallus granular, spreading, gray to greenish. Apothecia small, elevated margin. Disk flattened, black. Spores dark-brown, distinctly four-celled, usually constricted at the septa, $16 \mu \times 6.5 \mu$.

\section{Buellia.}

The Buellias are well characterized, and are represented by a large number of species. The general characters of the thallus resemble those of Biatora and Lecidea. The apothecia are medium in size and are 
more or less irregular in outline. 'The spores are normally two-celled, constricted at the middle, dark to nearly black in color.

The Buellias have a wide range, and occur upon rocks, rarely upon trees and old fences. 'They are found at very high altitudes. Formerly the Buellias were united with the Lecideas. Reinke considers them closely related to Rinodina.

1. Buellia Schoreri. Thallus granular to indistinctly areolate, brownish. Apothecia very small. Disk dark-brown to black. Spores two-celled, darkbrown, not constricted, ends blunt, $12 \mu \times 7 \mu$.

2. Buellia parmeliarum. Thallus granular, greenish to ash-gray. Apothecia small. Disk convex, black. Spores oblong, dark-brown, $12 \mu \times 5 \mu$.

This plant is said to be normally parasitic upon species of Parmelia. The majority of plants found upon Parmelia are, however, very likely parasitic fungi, as in those examined no thallus could be detected.

3. Buellia parasema. Thallus granular to more or less irregularly areolate, areoles sometimes scattered, gray. Apothecia medium to large, considerably elevated above the surface of the thallus. Disk flattened, margin somewhat elevated, black. Spores two-celled, dark-brown, not constricted, sometimes narrowed at one end and slightly curved, $14 \mu \times 6 \mu$.

4. Buellia dialyta. Thallus from thin and uniformly spreading to minutely granular, granules often scattered, ash-gray. Apothecia small, somewhat elevated above the thallus. Disk convex, black. 
Spores two-celled, sometimes constricted, large, darkbrown, $24 \mu \times 11 \dot{\text {. }}$.

5. Buellia stellulata. Thallus of rather small, irregular, scattered areoles. A pothecia very small, barely extending above the surface of the thallus. Disk flat, brown to black. Spores two-celled, not constricted, ends blunt, $9 \mu \times 5 \mu$.

6. Buellia Eliza. Thallus of minute, more or less scattered granules, gray to greenish. A pothecia medium. Disk reddish-brown to black. Spores in various stages of development, two-celled and dark-brown when mature, $13 \mu \times 7 \mu$.

7. Buellia myriocarpa. Thallus thinly granular, ash-gray to greenish. Apothecia small, numerous, somewhat elevated above the thallus. Disk flattened, black. Spores two-celled, dark-brown, $14 \mu$ $\times 7 \mu$.

8. Buellia colludens. Thallus of very small, closely adnate, angular squamules with slightly depressed margins, gray to brownish. Apothecia small, variable in form, somewhat elevated above the thallus. Disk flattened, black. Spores two-celled, constricted, darkbrown, $15 \mu \times 6.5 \mu$.

9. Buellia coracina. Thallus of comparatively large, rather irregular squamules, with upper surface more or less convex, dark to nearly black. Apothecia of medium size, adnate upon the thallus. Disk convex, dark to black. Spores two-celled, not constricted, darkbrown, $15 \mu \times 8 \mu$.

10. Buellia badia. Thallus of small, angular, closely adnate squamules, tawny to brownish. Apothecia 
small, immersed. Disk flattened, black. Spores twocelled, brownish when mature, $8 \mu \times 4.5 \mu$.

11. Buellia spuria. Thallus of rather large angular squamules, somewhat convex above with dark margin, light to gray. Apothecia of medium size, adnate, only slightly extending above the thallus, irregular in form and size, often covering the entire squamule, margin somewhat elevated. Disk black. Spores twocelled, dark-brown, $15 \mu \times 7 \mu$.

12. Buellia pulchella. Thallus well developed, consisting of gyrate folds, resembling the convolutions of the brain, greenish-yellow. Apothecia medium to large, sessile. Disk convex, black. Spores two-celled, constricted, dark-brown, $14 \mu \times 7 \mu$.

\section{Catillaria.}

This genus requires further careful study. Tuckerman and others included it in the uncertain group Heterothecium. Its general characters resemble those of Lecidea. The hypothecium is dark-blue to black. Thallus is rudimentary. The algæ are no doubt Pleurococcus. Spores two-celled, large, colorless. Only one species from the United States has come to my notice.

1. Catillaria grossa. Thallus thin, papery, smooth, almost shining. Apothecia medium in size. Disk flattened, margin elevated, black. Spores two-celled, colorless, large.

C. grossa occurs upon bark of ash and perhaps other trees. It is not common, and nothing definite is known concerning its distribution. 


\section{Megalospora.}

This genus has also been included under Heterothecium. Its general characters are like those of Catillaria; the apothecia are somewhat larger and the disk more convex. The thallus presents almost the same external appearance as to color and general conformation ; the algæ are, however, Protococcus instead of Pleurococcus. The hypothecium is black or blueblack. Each spore-sac contains one, rarely two, large simple spores. The spore-wall consists of two layers, of which the outer one is quite thick and gelatinous.

1. Megalospora sanguinaria. Thallus light-gray. Apothecia comparatively large. Disk convex. Spores large, simple, colorless, outer spore-wall (exosporium) thick, $103 \mu \times 40 \mu$.

The above is the only species which came to my notice. It is not very common and occurs upon trees. It seems to be northern in its range.

\section{Lopadium.}

This genus is also taken from the conglomerate group Heterothecium. The thallus is crustose and uniformly spreading. The algæ are Chroolepus umbrina. Soralia are common. The apothecia are of medium size, loosely sessile upon the thallus, discoid. A reddish-brown or nearly black color pervades almost the entire apothecial structure. The spores are multilocular, large, and vary from colorless to brown and reddish-brown.

A few species are reported which seem to be 
southern in their range. They occur upon trees and mosses.

1. Lopadium pezizoideum. Thallus granular, uniformly spreading, thin, grayish. Apothecia of medium size, discoid, not numerous. Disk convex, dark. Spores large, one in each spore-sac, colorless, and simple in early stages of development, multilocular and dark when mature, $90 \mu \times 35 \mu$.

\section{Gyalecta.}

This is one of the older genera, and hence it would be reasonable to assume that it is well understood, but such is not the case. A large number of herbarium specimens labelled as Gyalectas belong to other genera. It is in fact impossible at the present to give the exact limitations of the genus. The following are some of the generic characters, as far as they could be determined.

The thallus is crustose in the majority of species; becoming minutely foliose in the higher species, color generally dark. The algæ are Protococcus. Apothecia are discoid. Disk is flattened to somewhat cup-shaped, dark. The hypothecium is usually colorless. The spores are quite large and multilocular, oblong to spindle-shaped, usually colorless, though some are evidently dark in color.

They occur upon rock and trees. Nothing definite can be stated as regards range and frequency of occurrence.

1. Gyalecta cupularis. Thallus crustose, evenly spreading, gray to dark. Apothecia discoid. Disk 
concave, reddish-brown, margin somewhat rugose. Spores multilocular, somewhat colored when mature, $40 \mu \times 20 \mu$.

\section{Psora.}

By some authors this genus is classed with Biatora, others class it with Lecanora. It is the first group of the Lecideacere in which the thallus is typically foliose. The thallus is simple, entire, small, and is usually closely adnate to the substratum, or the entire lobes may be plicate or ascending. The lobes never became large, scarcely exceeding one-fourth of an inch in diameter. They are, however, comparatively thick, thus giving them considerable rigidity. Their color is quite variable; the upper surface varies from light-gray to black; the lower surface is usually of a lighter color.

The apothecia are small to medium, distributed over the thallus, but sometimes ranged about the margin. They are somewhat discoid and more or less immersed in the thallus. The disk is dark-colored (rusty). The spores are simple, elliptical, colorless, closely resembling those of Biatora.

The Psoras occur upon rock and soil; they seem to be quite generally distributed.

1. Psora icteria. Thallus-lobes rather small, scarcely ascending, margin somewhat crenate and light colored; upper surface greenish becoming tawny with age; light colored beneath. Apothecia rather small, sessile. Disk nearly black. Thecium and hypothecium yellowish. Spores simple, colorless, elliptical, $16 \mu \times 7 \mu$. 
2. Psora atro-rufa. Thallus of rather small lobes, margin more or less crenate and lobulate, closely adnate to the substratum, color dark. Apothecia medium, sessile, disk slightly convex, dark. Spores simple, colorless, elliptical, $14 \mu \times 5 \mu$.

3. Psora rufonigra. Thallus-lobes rather small, somewhat ascending, margin wavy and lobulate, upper surface dark reddish-brown to nearly black. Apothecia medium to large, marginal. Disk convex, black. Spores colorless, simple, elliptical, $12 \mu \times 5 \mu$.

4. Psora decipiens. Thallus-lobes usually ascending, closely crowded, margin more or less crenulate, lobed, turned back and white; upper surface brown to tawny; white beneath. Apothecia much as in $P$. icteria. Spores simple, colorless, elliptical, $14 \mu \times 6 \mu$.

5. Psora Russellii. Thallus-lobes rather large, entire, quite thick and rigid, margin somewhat crenate, white, slightly turned up; upper surface brownish, lower surface light color. Apothecia of medium size, usually marginal. Disk convex, brown. Spores simple, colorless, elliptical, $11 \mu \times 4.5 \mu$.

\section{Gyrophora.}

The representatives of this genus are highly interesting, both as to size and form and as to the economic uses to which they have been put in the past.

The thallus is typically foliose, and varies in size from medium to very large. The smaller thalli may either be single or form a cluster, more or less imbricate. No matter what the size of the thallus may be, it is always entire and held to the substratum by 
the umbilicus. The margin is generally somewhat torn. The prevailing color of the upper surface is gray to nearly black; the lower surface is quite black, bearing black rhizoids or scaly lamina.

The apothecia are rather peculiar in structure. They are sessile upou the thallus, and on examination with a pocket-lens the disk presents a convoluted appearance, reminding one of the convolutions of the dentine in the tooth of a ruminant. The disk is convex, black. The spores are simple, elliptical, colorless.

The Gyrophoras are northern in their range, but are also quite common in the mountainous regions of the temperate and torrid zones. They grow upon rock and soil. Quite generally this group is combined with Umbilicaria.

1. Gyrophora hyperborea. Thallus medium, nearly entire, margin somewhat incised and torn, rugose above, dark to black; usually smooth and somewhat lighter below. Apothecia small to medium. Disk flattened, black. Spores ovoid, colorless, somewhat curved, $14 \mu$ by $7 \mu$.

2. Gyrophora proboscidea. Thallus medium size, somewhat lobed or folded, and rugose above, margin torn and occasionally perforate, bearing cilia, gray, dark near margin; lower surface pale toward centre, becoming darker toward margin. Apothecia of medium size, scattered over the thallus, except at the centre and margin. Disk flattened, black. Spores simple, colorless, elliptical or ovoid, slightly curved, $16 \mu \times 7 \mu$. 
According to Porcher, Icelanders use this lichen as an article of food; more frequently for dyeing woollen cloth a brownish-green color.

8. Gyrophora erosa. Thallus medium in size, more or less lobed, margin ragged and reticulately perforate, entire upper surface more or less reticulate, dark color; lower surface fissured, areolate, lighter than upper surface. A pothecia small. Disk convex, black. Spores small, colorless, granular, $10 \mu \times 4.5 \mu$.

4. Gyrophora floculosa. Thallus small to medium, thin, margin somewhat lobed and torn; upper surface dark-brown, bearing numerous fine thalloid outgrowths; lower surface of nearly the same color and reticulately veined. No fertile specimens have come to my notice.

5. Gyrophora Mühlenbergii. Thallus medium to large, margin more or less torn; upper surface smooth, pitted and rugosely folded, ash-gray, darker toward the margin; lower surface more or less reticulate, fringed toward the margin, dark-brown. Apothecis from medium to large, situated in pits, scattered toward the margin of thallus. Disk convex, black. Spores simple, elliptical, colorless, $10 \mu \times 5 \mu$.

This is one of the lichens known as "tripe de roche," and was used by Sir John Franklin on his journey to the polar seas. It was said to be "agreeable and nutritious," although, like other lichens, it contains an objectionable bitter principle.

6. Gyrophora vellea. Thallus large, entire, margin more or less incised and somewhat broken or torn, upper surface smooth or finely powdered, gray; lower surface brown to dark, bearing numerous rigid cilia. 
Apothecia in slight depressions of thallus, marginal, small to medium. Disk convex, black. Spores simple, colorless, elliptical, slightly granular, $10 \mu$ by $7 \mu$.

"Some varieties of this species are imported to a considerable extent into the London market from the Norwegian mountains, for the manufacture of orchill and cudbear, under the name of 'Norway rock moss,' or 'velvet or velutous moss.' Like most of its cospecies, it grows chiefly on granitoid rocks on very high mountains, or in arctic or sub-arctic regions. On the Mexican volcano of Orizabo it occurs at a height of between 13,000 and 14,000 feet, along with other species. This is another of the lichens which constitute the 'tripe de roche' of sub-arctic America and the polar regions. This black, leathery, forbidding-looking ' rock-tripe' is often boiled and eaten by the Canadian hunter when pressed by hunger. In Iceland it is frequently eaten in periods of scarcity as a supplement to the more nutritious 'Iceland moss'; and it has been frequently mentioned in the narrative of the polar voyages as having been the means of saving the crew from perishing by starvation. The nutritive properties of these lichens depend on the presence of a large amount of starchy matter (lichenin, lichenstarch). When boiled they yield, like Cetraria Islandica, a firm, nutrient jelly, which is, however, accompanied, as in that lichen, by a bitter principle possessed of purgative properties. Linnæus speaks of some $G y$ rophoras as superior in nutritive qualities to the "Iceland moss." " - Lindsay.

7. Gyrophora Dillenii. Thallus large to very 
large, entire, margin somewhat lobed or torn; upper surface smooth, centre raised, gray to brown; lower surface dark. Apothecia medium to large, scattered, convex, black. Spores large, colorless, simple, very granular, ovoid, not curved, $24 \mu \times 12 \mu$.

\section{Umbilicaria.}

The general appearance and structure of the thallus and apothecia of Umbilicaria shows its close relationship to Gyrophora. It differs, however, in that rhizoids, cilia and scaly plates (lower surface) are wanting. Coloration is the same in both. In Umbilicaria the thallus is more or less pustular. The important distinguishing characters occur in the spores, which in this genus are large, brown-colored, multilocular, each spore-sac bearing a single spore.

The algæ in Gyrophora and Umbilicaria are evidently Protococcus, though they differ in form from those occurring in other lichens; further investigation may prove it another alga.

The range and habitat of this group is much as that of the preceding. It is represented by fewer species. When dry, these lichens are very brittle, hence the collector will find it necessary to gather them when the atmosphere is moist, or to pour water upon them before attempting to remove them from the rock upon which they grow.

1 Umbilicaria papulosa. Thallus medium to large, thin, margin more or less lobate and torn; pustular, pustules quite separate and uniform in size; dark-gray above; lower surface reticulately pitted, 
smooth, colored much as upper surface. Apothecia small, scattered over greater portion of thallus. Disk flattened, black. Spores one, rarely two, light-brown to dark-brown, multilocular, elliptical, $71 \mu \times 34 \mu$.

2. Umbilicaria Pennsylvanica. Thallus medium to large, thin, more or less wavy, margin somewhat torn; pustules much as in $U$. papulosa; dark-gray above; black and reticulately fitted below. Apothecia large, elevated margin. Disk flat, black. Spores $68 \mu \times 27 \mu$, otherwise as in U. papulosa.

3. Umbilicaria pustulata. Resembles U. papulosa with the exception that the pustules are larger, confluent; lower surface more reticulately pitted. Apothecia more numerous and showing a tendency to coalesce. Spores as in U. papulosa.

"According to Linnæus, a beautiful red color may be prepared from this lichen, and it may be converted into 'an exceeding fine black paint" " - Porcher.

\section{GRAPHIDACEAE.}

In all probability the family is out of its natural position as here given. The reason that it is placed above the Lecideacea is because it was believed that Rocella should be included in the family, in accordance with the views held by Reinke. It is, however, probable that Rocella belongs to the Parmeliacea. If the exclusion is admitted, the Graphidacea are lowly organized lichens, in which the thallus never develops beyond the crustose stage, and hence the family would really be placed before the Caliciacea. 
The present classification will, however, be retained, although Rocella will be included under Parmeliacea.

The Graphidacea are essentially southern in their range, where they also attain their maximum development; particularly is this true of Graphis and Arthonia. The thallus is crustose and quite variable in color and thickness. In a large per cent. of the representatives the thallus is hypophlœodal, that is, it occurs below the surface of the substratum and is therefore invisible to the naked eye. The apothecia are characteristic; instead of being discoid, as in the majority of lichens, they are linear, stellate or irregular in outline. 'They belong to the fungal type.

\section{KEY TO THE GENERA.}

Spores two to eight-celled or simple, colorless.

Two-celled. . . . . . . 1. Hazslinskya.

Four to six-celled, elliptical _. . . 2. Opegrapha.

Eight-celled, large, oblong, curved . . . 3. Graphis.

Simple . . . . . . . 4. Xylographa.

Four-celled, one end narrowed . . . . 5. Arthonia. ${ }^{1}$ Spores multilocular.

Constricted in the middle . . . . 6. Mycoporum.

Not constricted, colorless . . . . . \%. Arthothelium.

\section{Hazslinskya.}

A lowly organized group having only a few representatives. The thallus, as well as the apothecia, begin their development below the surface of -the substratum. The algæ are Chroolepus. The apothecia soon break through and appear as minute black dots; upon examination with a lens they are seen to be more or less orbicular or somewhat elongated, with

1 Some of the southern Arthonias have colored spores. 
irregular outline. The disk ${ }^{1}$ is flattened and dark in color. The spores are colorless, of medium size, twocelled; one cell larger, constricted at the septum.

1. Hazslinskya demissa. Thallus partly below the substratum, rudimentary, light color. Apothecia oval, irregular in outline; single, not in groups, as in the European form $H$. gibberulosa, opening by an oval pore. Disk dark. Spores colorless, two-celled, constricted at the septum, one cell larger, $17 \mu \times 8 \mu$.

This lichen is usually classified as Opegrapha $d c$ missa.

\section{Opegrapha.}

Thallus rudimentary and mostly hypophlœodal, finally forming a thin film over the substratum. The algæ are Chroolepus. The apothecia are usually numerous, small, linear, more or less curved, projecting somewhat above the surface of the substratum. Disk black. The hypothecium is also black. The spores are colorless, elliptical to almost acicular, usually four-celled. They occur upon trees.

1. Opegrapha varia. Thallus finely pulverulent, light-colored, mostly hypophœodal. Apothecia elliptical, oblong to short-linear. Disk black. Spores are four to six-celled, colorless to pale yellow, $23 \mu \times 2.5 \mu$.

2. Opegrapha vulgata. Thallus rudimentary, whitish. Apothecia elliptical to distinctly linear, rather small. Spores acicular, indistinctly four to sixcelled, colorless, $24 \mu \times 2.5 \mu$.

1 The term " disk" is scarcely applicable to the irregular apothecia of this family, but will be retained to aroid the necessity of introducing a new term. 


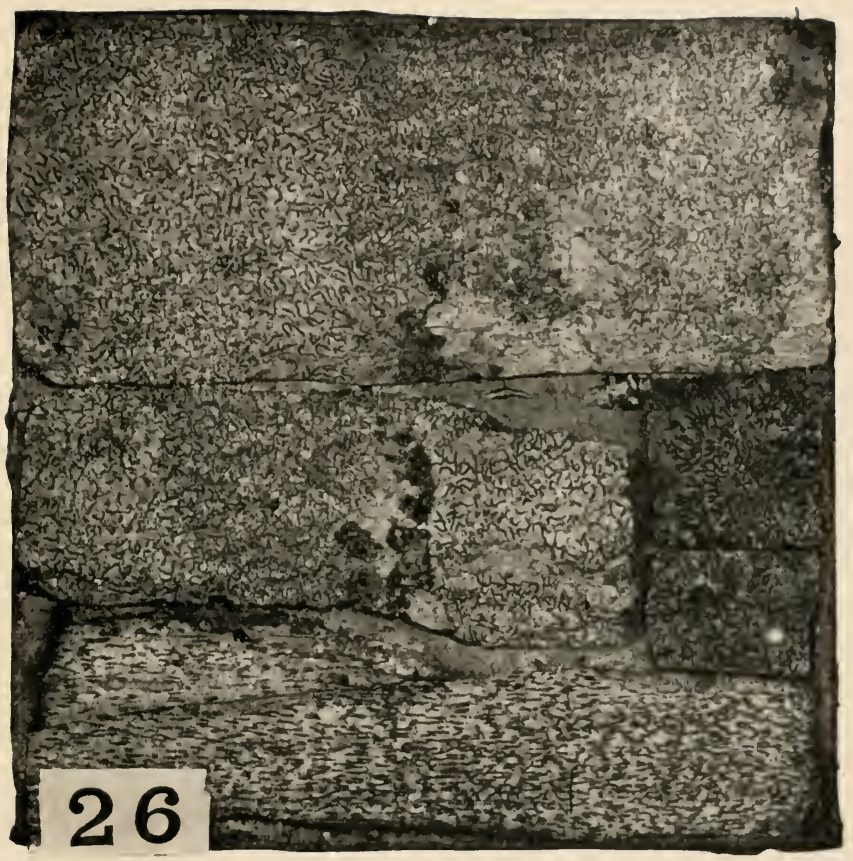

PLATL: Lo. ('rustose Types. From the collection of $\mathrm{X}$. Y. ('lark in the herbarium of the ('aldformat Acatemy of sictenere. Cimplis scriplu. 



\section{Graphis.}

This genus is well represented in the southern states. The thallus is always crustose, though it may attain considerable thickness. The thallus, as well as the apothecia, begins development below the surface of the substratum, but soon breaks through after which the thallus rapidly spreads. The algæ are Chroolepus.

The apothecia are distinctly linear, often branching, bent or angular. The disk is black in the northern species, black or white in the southern forms. The color of the thallus also varies from greenish-gray to white. The spores are comparatively large, six to twelve-celled, colorless, somewhat curved; the more or less gelatinous exosporium is wavy in outline.

The species occur upon trees, preferably the smoother barks.

1. Graphis elegans. Thallus hypophloodal. Apothecia linear, branching, prominent. Disk black. Usually sterile.

This lichen closely resembles G. scripta and is, perhaps, merely a varietal form of that species.

2. Graphis scripta. Thallus hypophlœodal. Apothecia as in $G$. elegans, less prominent. Spores eightcelled, colorless, variable in size, $34 \mu \times 11 \mu$.

This lichen is common everywhere.

3. Graphis dentritica. Thallus rarely becoming epiphlœodal at maturity. Apothecia radially linear and branching. Disk black. Spores colorless, usually eight-celled, one end often narrowed, $24 \mu \times 6.5 \mu$.

4. Graphis eulectra. Thallus soon becomes epiphlœodal, light-gray to nearly white, evenly spreading, 
smooth. Apothecia linear, branching, partially enclosed by the thallus. Spores colorless, eight-celled, $30 \mu \times 8.5 \mu$.

\section{Xylographa.}

The thallus begins its development below the surface of the substratum, finally spreading over the surface in the form of a thin whitish layer. The algæ ore Chroolepus and Protococcus. The apothecia are linear or irregular, extending parallel to the fibres of the woody substratum. The disk is dark. The hypothecium is nearly colorless. The spores are rather small, simple, elliptical, colorless and usually sparingly present.

They occur upon rotten logs and bark of trees.

1. Xylographa parallella. Thallus becomes epiphlœodal at an early period, smooth, uniform, lightgray. Apothecia linear, extending parallel to the fibres of the wood. Disk dark. Spores simple, colorless, ovoid, $15 \mu \times 6.5 \mu$.

This plant occurs upon rotten logs, and is characteristic in appearance. The algæ are Protococcus.

2. Xylographa opegraphilla. Thallus soon becomes epiphlœodal, distinct, areolate, areoles easily removed, pale-gray. Apothecia short-linear, rarely branching. Disk pale-brown to dark. Spores simple, ovoid, colorless, $14 \mu \times 6 \mu$.

In this lichen the algæ are Chroolepus.

\section{Arthonia.}

This is in many respects a difficult group for study, principally because its representatives are numerous 
and lowly organized. The difficulty is increased by the fact that many species are generally sterile, that is, they are without spores though apothecia may be present. The thallus is deficient and the algal characters are variable; in some cases it is evidently Chroolepus, in others, Protococcus. Further investigation may make it advisable to subdivide the group upon these algal differences.

The apothecial characters are also variable. Along with the thallus, the apothecia begin their development below the surface of the substratum, breaking through some time before maturity; rarely they remain covered over by a thin layer of the thallus and substratum. They are small, irregular in outline, never distinctly linear; sometimes they are stellate or tend to become linear, with radiating projections. The disk and hypothecium are dark, sometimes reddishbrown.

The spores are characteristic in form; they are oblong, either colorless or dark-colored, usually fourcelled, the ends blunt, narrowed toward one end causing it to resemble the outline of the sole of a shoe.

The Arthonias are southern in their range, though less so than Graphis. They occur upon trees.

1. Arthonia astroidea. Thallus indistinct, mostly hypophlœodal. Apothecia numerous, irregular, stellate, sometimes somewhat elongated; only slightly raised above the substratum (bark). Disk black. Spores colorless, four-celled, $12 \mu \times 5 \mu$.

2. Arthonia dispersa. Resembling A. astroidea; the apothecia are fewer and more scattered. 
Species of Nostoc and Sirosiphon (S. pulvinatus) occur parasitically upon many of the Arthonias.

3. Arthonia quintaria. Thallus rudimentary, partly hypophlœodal, evenly spreading, light-gray. Apothecia small, irregular to somewhát linear, scattered. Spores colorless, four to seven-celled, somewhat curved, narrowed toward one end, $24 \mu \times 7 \mu$.

4. Arthonia tadiosa. Thallus rudimentary, partly hypophlœodal, evenly spreading, extending over the apothecia in the form of a thin film, light color to greenish. Apothecia medium, numerous, irregularly stellate. Disk dark. No spores came to my notice. The spore-sacs were either entirely empty or contained only immature, gelatinized spores.

5. Arthonia radiata. Thallus much as in $A$. quintaria. Apothecia more numerous, larger, irregularly stellate. Spores colorless, four.celled, $17 \mu \times 4.5 \mu$.

6. Arthonia punctiformis. Thallus rudimentary, partly hypophlœodal, evenly spreading, light-gray. A pothecia very small, irregular in form. Disk dark. No mature spores came to my notice.

7. Arthonia polymorpha. Thallus partly hypophloodal, evenly spreading, pale color. Apothecia of very irregular outline, thinly overspread by the thallus. Disk dark-brown. No spores seen.

8. Arthonia lecidella. Thallus distinct, irregularly areolate, light bluish-green (Chroolepus and Protococcus both present). Apothecia rounded, slightly raised. Disk somewhat convex, dark. Spores as in $A$. astroidea.

9. Arthonia glabrata. Thallus quite distinct, some- 
what areolate, grayish in color, partially enclosing the apothecia. Apothecia comparatively large, irregular in outline. Disk dark. Spores not seen.

10. Arthonia atra. Thallus rudimentary, mostly hypophlœodal, light color. Apothecia numerous, oblong to linear or branching. Disk dark. Spores typical, $16 \mu \times 4.5 \mu$.

11. Arthonia varia. Thallus rudimentary, lightgray. Apothecia distinct, linear, not branching. Spores typical, $15 \mu \times 3 \mu$.

\section{Mycoporum.}

This is a small group whose position is rather uncertain. It is evidently closely related to the Graphidacere.

The thallus is rudimentary and begins its development below the surface of the substratum. It, however, soon breaks through, forming a deficient crustose thallus. The algre are perhaps Protococcus, though they also have a resemblance to Pleurococus.

The apothecia are irregular in outline but never distinctly linear. Disk and hypothecium are black. The spores are large, eight in number, multilocular, colorless to brownish, and constricted at the middle.

The few representatives occurring in the United States seem to be southeru in their range, occurring upon trees.

1. Mycoporum pycnocarpum. Thallus deficient, evenly spreading, grayish. Apothecia small, scattered, irregular in outline, scarcely raised above the thallus and substratum. Spores large, multilocular, 
colorless to brown, constricted at the middle, $84 \mu$ $\times 40 \mu$.

\section{Arthothelium.}

This group is usually associated with Arthonia. It also resembles Mycoporum in many respects.

The thallus is rudimentary, often indistinctly areolate, grayish to dark in color. The algæ are Chroolepus. The apothecia are comparatively large, stellate. The disk is dark. The entire thecium and hypothecium may be dark; again it is found to be colorless.

The spores resemble those of Mycoporum, but differ in that they are colorless and not constricted at the middle. Each spore-sac bears eight spores, which is uncommon with lichens bearing such large spores.

The Arthothelias are southern in their range. They occur upon trees, most frequently upon hickories.

1. Arthothelium spectabile. Thallus rudimentary, areolate. Apothecia numerous, comparatively large, irregular, stellate. Disk black. Spores large, multilocular, colorless, $78 \mu \times 40 \mu$.

\section{PHYSCIACEA.}

The representatives of this family are characterized by the two-celled spores in which the protoplasmic contents are joined by a slender thread, a characteristic not noticeable in spores of any other lichen-group.

The thallus varies from typically crustose to foliose and fruticose, and, as is natural to suppose, it is variable in size, though it never attains any very great dimensious. The foliose forms are often mistaken 
for species of Parmelia, otherwise there is little difficulty in recognizing the Physciacea.

The apothecia belong to the thalline type, that is the algæ of the thallus enter into its structure; they are discoid, rarely immersed, the disk is flattened or concave, sometimes convex.

The Physciacea seem to be better adapted to resist extremely dry periods than most lichens. They are rich in deposits of lichenic acids, which cause some of the characteristic colorations in thallus and apothecia.

\section{KEY TO THE GENERA.}

Thallus crustose, areolate, margin often lobed.

Spores brown, thallus not bright-yellow . 1. Rinodine.

Spores colorless, thallus yellow to orange, 2. Placodium. Thallus foliose, gray, not yellow.

Hypothecium dark . . . . . . 3. Pyxine.

Hypothecium colorless . . . . 4. Physcia.

Thallus foliose to fruticose, often yellowish, 5. Theloschistes.

\section{Rinodina.}

This genus represents the lowest group of the Physciacea. The thallus is typically crustose, gray or greenish in most species; in $R$. oreina the thallus is of pale dirty lemon or sulphur color; in $R$. chrysomelana there is also a marked yellowish tinge. In some species a tendency toward the foliose type is noticeable. Usually the thallus is distinctly areolate and closely adnate to the substratum. The areoles are bounded by a thin black zone which some authors designate as the "hypothallus."

The apothecia are immersed or sessile. In the sessile forms the thalloid margin exteuds somewhat above 
the disk. In the immersed apothecia the disk is irregular in outline. The spores are dark in the majority of species. The algæ are Protococcus (excepting $R$. oreina).

The Rinodinas are quite common throughout the United States, but have a slight western and southern tendency. They occur upon rock and bark, less commonly upon soil and moss.

1. Rinodina constans. Thallus thin, evenly spreading, granular to areolate, grayish-green. Apothecia small to medium. Thalloid exciple slightly raised above the dark disk. Spores brown, $17 \mu \times 8.5 \mu_{0}{ }^{1}$

2. Rinodina Bishoffii. Thallus varies from thinly granular to quite thick and indistinctly areolate, brittle, closely adnate though readily removed, often leaving the apothecia behind. Apothecia rather small, slightly raised above the thallus. Disk flattened, black. Spores dark-brown, connecting thread often indistinct, septum thick, $17 \mu \times 12 \mu$.

3. Rinodina sophodes. Thallus of rather indistinct, more or less scattered, irregular areoles, grayish-green above, dark beneath. Apothecia small. Thalloid exciple, usually deficient. Disk black. Spores brown, slightly constricted at the middle, $22 \mu \times 8 \mu$.

4. Rinodina oreina. Thallus distinctly areolate, comparatively thick, lemon or sulphur color. Apothecia immersed, smali to medium. Disk black or darkbrown. Spores dark-brown, connecting thread not visible, septum thick, somewhat constricted, $10 \mu \times 6.5 \mu$.

1 Other generic spore-characters are given in the family description, which see. 
This lichen has been made the basis of the distinct genus (Dimetcena). Its spore-characters closely resemble those of Buellia. It occurs typically upon granitic rock.

5. Rinodina chrysomelana. Thallus rather thick, irregularly areolate, margin indistinctly lobulate; yellowish-green above, black beneath. Apothecia small, margin elevated above the dark flattened disk. Spores dark-brown, connecting thread distinctly visible, $25 \mu$ $\times 11 \mu$.

6. Rinodina turfacea. Thallus verrucose (warty), more or less branching, grayish-green. Apothecia from small to medium in size, margin extending slightly above the dark flattened disk. Spores brown, slightly constricted at septum, $25.5 \mu \times 12 \mu$.

\section{Placodium.}

The representatives of this genus are characterized by the orange coloration of the apothecial disk. The thallus varies from typically crustose to distinctly foliose, though it never attains any great size; in color it is usually yellow or orange, rarely gray to dark. The yellow color is due to the deposition of crystals of chrysophanic acid.

The apothecia are discoid, of medium size, sessile, with a distinct thalline margin. The spores are colorless, with terminal plasmic masses connected by a slender plasmic thread. The transverse septum is not distinct, as in Rinodina; rarely are the spores simple.

The distribution of the Placodias is much as that of Rinodina. They occur upon rock, also upon bark, fences 
and old buildings. Some of the species are confused with Theloschistes.

1. Placodium ferrugineum. Thallus granular and indistinctly areolate, variable shades of gray. Apothecia medium, margin scarcely raised. Disk flattened, rusty-brown to black. Spores typical, $17 \mu \times 8.5 \mu$.

2. Placodium cerinum. Thallus evenly spreading, granular, sometimes indistinctly areolate, dark-brown. Apothecia small. Disk convex, reddish-brown, margin not raised. Spores typical, $12 \mu \times 6.5 \mu$.

3. Placodium aurantiacum. Thallus varies from evenly spreading to coarsely granular and areolate, greenish-yellow or lemon color. Apothecia variable in size and number. Disk flattened or slightly convex, margin somewhat raised, reddish-brown. Spores typical, $17 \mu \times 8 \mu$.

4. Placodium citrinum. Thallus of powdery (soredioid) granules, areolate, lemon color. Sterile. No apothecia-bearing specimens have come to my notice. The plant is usually mutualistically or antagonistically associated with species of Lecanora, and it may be that the spores of the latter have been described as the spores of $P$. citrinum.

5. Placodium cinnabarinum. Thallus areolate, areoles sometimes scattered, bright-orange. Apothecia small, almost entirely immersed in the areoles. Disk concave, margin slightly paler than thallus. Spores typical, $9 \mu \times 4 \mu$.

6. Placodium murorum. Body of thallus of convex more or less irregular squamules, margin of elongated bifurcate lobules, closely adnate, orange color. Apo- 
thecia numerous, small to medium. Disk flattened or slightly convex, darker orange than thallus, margin scarcely raised. Spores typical, $10 \mu \times 5 \mu$.

Placodium murorum has been classed by authors with Lecanora as well as Parmelia. It occurs upon walls, rocks, bricks, tiles, mortar, etc.

7. Placodium elegans. Thallus distinctly foliose, radial growth, forked branching, lobes of uniform width, convex above, somewhat concave below, ends of branches turning down; orange above, dark-gray beneath with black rhizoids. Apothecia medium to large, cup-shaped. Disk orange. Spores typical, $10 \mu \times 8 \mu$.

This species as well as other species of Placodium has been classed with Parmelia. P. elegans is said to occur on granitic rock on the highest mountains. It has been collected on Orizaba at an elevation of $14,8.50$ feet. Agassiz brought it from the summit of the Jungfrau.

$$
\text { 3. Pyxine. }
$$

Only two species of this genus occur in the United States, one of which is probably not a Pyxine. $P$. sorediata is nearly always sterile. As represented by the only two species, the thallus is foliose, quite large, thin and closely adnate to the substratum, branching quite distinct. Color of the thallus ash-gray, resembling that of the Physcias, to which this group is evidently closely related. ${ }^{1}$

The apothecia are discoid. Disk dark, likewise the

1 Unless otherwise stated, the algæ of any lichen-genus or lichenpecies are Protococcus (Cystococcus humicola of Nägeli). 
hypothecium, which characterizes the genus. The spores are two-celled, the cells united by a plasmic thread, dark-brown.

1. Pyxine picta. Thallus thin, membranaceous, closely adnate to the substratum, indistinctly lobed toward the margin, older portion of the thallus more or less warty. Apothecia of medium size, discoid, sessile. Disk dark to black, flattened. Spores darkbrown, typical of the family, $18 \mu \times 7 \mu$.

2. Pyxine sorediata. Thallus much branched, lobed, long and of uniform width, grayish-green above, black, with numerous rhizoids, below ; numerous soralia occur along the upper margins of the lobes. Apothecia very rare. Disk flattened or convex, dark. Spores darkbrown, typical, $17 \mu \times 7 \mu$.

This lichen requires further careful study. It is perhaps not a Pyxine. Only scant and unsatisfactory apothecia-bearing material has come to my notice. It has been described as Pyxine cocoes, Parmelia sorediata, Pyxine cocoes variety sorediata, as a Physcia, etc.

\section{Physcia.}

The thallus is almost crustose in a few of the lower species; otherwise it is typically foliose, much-branched and extending flatly over the substratum. The color is usually gray tinged with green above, with a different color beneath, usually lighter, rarely dark to black, much of the dark coloration being due to rhizoids. In some species the margin of the thallus-lobes are lined with dark cilia. Whitish soralia are also common upon the thalli of many species. 
The apothecia belong to the thalline type, and are discoid, sessile. small to medium in size. The disk is dark in color. There is no yellow or orange coloration in this genus. It may also be mentioned that spermagonia occur upon many species. The spores are typical of the family, closely resembling those of Rinodina.

The Physcias have a wide range; the higher forms are somewhat southern. They occur upon bark and rock.

Formerly the Physcias were quite generally combined with Parmelia, from which group they are, however, readily distinguished by the spore-characters and by the differences in the appearance of the thallus.

1. Physcia adglutinata. Thallus crustose, thin, very closely adnate to the substratum, central portion areolate, warty, margin lobed, lobes of uniform width; dark colored. Apothecia small to medium. Disk darkbrown, margin slightly crenulate. Spores brown, typical, $15 \mu \times 8.5 \mu$.

2. Physcia obscura. Thallus comparatively small, branching, firmly attached to the substratum, greenish-gray above, black beneath, with numerous rhizoids. Apothecia small to medium, margin extending above the dark-brown disk. Spores brown, typical, $24 \mu$ $\times 10.5 \mu$.

3. Physcia setosa. Thallus much as in $P$. obscura, lobes broader, often bearing soredia, black below, with densely crowded black rhizoids. Apothecia rare; none have come to my notice.

4. Physcia casia. Thallus comparatively small to 
medium, branching; lobes linear, slender, pale-gray above, with darker soralia, slightly darker beneath, with rigid rhizoids. Apothecia not seen.

5. Physcia tribacea. Thallus rather small, minutely branched, lobes not uniform in size, crenulate, greenishgray above, light color beneath, rhizoids few. Apothecia small to medium, margin entire. Disk dark-brown to black. Spores brown, oblong, ovoid, $17 \mu \times 8 \mu$.

6. Physcia stellaris. Thallus rather small, branched, lobes of uniform width, lying flat upon the substratum, ash-gray to brown above, light-brown beneath, rhizoids comparatively few. Apothecia as in P. tribacea. Spores brown, typical, $19 \mu \times 10.5 \mu$.

7. Physcia pulverulenta. Thallus large, branched, lobes variable from linear to broad, brittle, sometimes bearing minute conical or strap-shaped outgrowths; light-gray to brown, overspread by a translucent white coloration. Apothecia medium to large, margin slightly elevated and bearing conical or warty outgrow ths. Disk dark-brown, with a translucent white coloration. Spores dark-brown, constricted in the middle, connecting thread not distinct, $32.5 \mu \times 17 \mu$.

8. Physcia aquila. Thallus large, much branched, lobes linear, gray to brown above, nearly the same color below with large dark rhizoids, older parts of thallus and apothecia bearing numerous conical outgrowths or small thalloid lobules. Apothecia medium, margin often isidioid. Disk dark-brown. Spores large, brown, $29.5 \mu \times 18.5 \mu$.

9. Physcia hypoleuca. Thallus large, branched, adherent to the substratum, ash-gray above, pale beneath, 
rhizoids sparingly present and black. $\Lambda$ pothecia numerous, medium to large, cup-shaped, margin incurved, crenate. Disk dark-brown. Spores brown, typical, $36 \mu \times 17 \mu$.

10. Physcia speciosa. Thallus branched, lobes strapshaped, bearing a few cilia, usually lying close, but only loosely attached to the substratum, greenish-gray above, lighter color beneath with comparatively few dark rhizoids. Apothecia medium to large, cup-shaped, crenulate margin curved inward. Spores brown, typical, $21 \mu \times 11 \mu$.

11. Physcia comosa. Thallus branched from two to about six times, lobes ascending and of quite uniform width ; numerous, long, slender, dark cilia from the margin, rarely from the upper surface of the thallus as well ; uniform, pale ash-gray above, paler below, no rhizoids. Apothecia terminal, margin extending considerably above the gray disk. Spores brown, $17 \mu \times 34 \mu$.

12. Physcia hispida. Thallus much as in $P$. comosa but with lobes inflated at the tips, cilia usually more slender and numerous. Apothecia medium, margin only slightly raised above disk. Disk gray to nearly black. Spores brown, $20.5 \mu \times 11 \mu$.

13. Physcia ciliaris. Thallus much branched, lobes linear, somewhat ascending, branches terminating in long slender cilia, which are usually darker than the lobes; ash-colored to dark-brown above, nearly the same color beneath, no rhizoids. Apothecia rare, medium, cup-shaped, bearing some short cilia. Disk brown to dark. Spores dark-brown, $35 \mu \times 17 \mu$. 


\section{Theloschistes.}

The thallus varies from almost foliose to fruticose. The fruticose forms are much branched and usually bear long grayish cilia along the margin of the lobes. Usually there is more or less of a yellowish tinge; in some only a grayish color. Soralia are less common than in Physcia.

The apothecia are discoid, usually larger than in Physcia. Disk orange, yellowish, in some species darkgray to nearly black. The spores resemble those of Placodium, from which this group is perhaps phylogenetically derived.

The Theloschistes are more southern and western than the Physcias. They occur upon bark, rock, old walls, fences, old buildings, etc. Frequently they are associated with species of Physcia.

1. Theloschistes polycarpus. Thallus foliose, lobe short, rounded, dirty lemon to orange. Apothecia usually small, very numerous, the entire margin of the thallus studed with them. Disk concave, orange. Spores colorless, typical, $15 \mu \times 8 \mu$.

2. Theloschistes lychneus. Thallus foliose, branching, lobes broad and more or less ascending, soralia often present; orange above, lighter color beneath. Apothecia rare, medium size. Disk flattened, reddish-brown. Spores colorless, typical, $12 \mu \times 8.5 \mu$.

3. Theloschistes concolor. 'Thallus foliose, minutely branching, lobes of uniform width, not ascending, greenish-yellow above, gray beneath. Apothecia of medium size, cup-shaped, margin somewhat fibrillose. Disk of the same color as thallus. The spores are 
small, colorless and cells not distinctly terminal, $8.5 \mu \times 5 \mu$.

4. Theloschistes parietinus. Thallus always distinctly foliose, but variable in the development of the lobes; lobes usually short and rounded and somewhat upturned at the margin, pale-lemon to reddish-brown. Apothecia from medium to large. Disk orange. Spores colorless, typical, $12 \mu \times 7 \mu$.

This lichen has quite generally been classified as Parmelia parietina; also as Physica parietina. An older name, Candelaria, was derived from the fact that the lichen was used by the Swedes to give a yellow color to candles used in religious ceremonies. In England it has been extensively used to color Easter eggs. This is the lichen which was recommended as a substitute for quinine (1815). It was also highly recommended as an astringent in hemorrhages and as a febrifuge. It occurs in London drug-shops as "Common yellow Wall-moss," being probably chiefly utilized by the taxidermist. It is southern in its range.

5. Theloschistes chrysophthalmus. Thallus fruticose, branching, lobes flat, terminating in rigid cilia; yellowish-orange above, grayish beneath. Apothecia usually terminal, medium to large, margin usually ciliate. Disk orange. Spores colorless, typical, $14 \mu$ $\times 7.5 \mu$.

This is a beautiful plant, growing in tufts upon trees.

6. Theloschistes flavicans. 'Thallus fruticose, much branched, pendant, soralia often present, ciliate; yellowish-gray to reddish-brown. Apothecia medium to 
large, lateral or terminal. Disk redlish-brown. Spores colorless, typical, $16 \mu \times 7.5 \mu$.

7. Theloschistes leucomela. Thallus fruticose, much branched, lobes uniform, flat, long, ciliate; gray above, lighter beneath. Apothecia large, margin ciliate. Disk dark-gray. Spores light-brown, large, $51 \mu \times$ $22 \mu$.

This is a southern species and a very handsome plant. Fine specimens from Lower California have come to my notice. It would have been perhaps more correct to classify this lichen with Physcia, in accordance with Liudsay and others.

\section{VT. PARMELIACE E. 1}

In this family the thallus varies from typically crustose to typically foliose and fruticose. In all forms above the crustose types the thallus is much branched. The apothecia belong to the thalline type; they are discoid, and attain their maximum size in such genera as Usnea, Parmelia and Peltigera.

The position and limitation of the family are dependent upon the following characters: 1. The absence of stipes and podetia excludes it from the Caliciacea and Cladoniacer. 2. The presence of the thalline apothecia excludes it from the Lecidiacer. 3. The nonunion of the spore-cells excludes it from the Physciacea. 4. Presence of discoid sessile apothecia separates it from the Graphidacea and Verrucariacea. 5. The

1 In the study of most of the genera of this family I received specimens from the collection of my friend W. W. Calkins, for the use of which I express my sincere gratitude. 
absence of blue-green alga (Cyanophycea) finally separates it from the Collemacea and Pannariacea.

\section{KEY TO THE GENERA.}

Thallus crustose and areolate to thickly warty and minutely foliose.

Spores not simple.

Multilocular, dark . . . . 1. Urceolaria.

Five to seven-celled, acicular, colorless . . . . . . 2. Hematomma.

Spores simple, colorless.

Usual size and number (8) . . . 3. Lecanora.

Very minute and numerous (200) . 4. Acarospora.

Thallus foliose, lobed or branching, spores colorless.

Spores two-celled . . . . . . 5. Speerschneidera.

Spores simple.

Thallus greenish, lobes never erect . 6. Parmelia.

Thallus brownish, lobes sometimes erect........ \%. Cetraria.

Thallus fruticose.

Lobes distinctly flattened, spores colorless.

Spores two-celled . . . 8. Ramalina. Spores simple . . . 9. Rocella.

Lobes not distinctly flattened, yellowish . . . 10. Evernia.

Lobes cylindrical, filamentous and very long, spores simple.

Central hyphal core wanting. Thick exosporium . . . . . 11. Alectoria. Normal exosporium . . . 12. Bryopogon. Central hyphal cores present . . 13. Usnea.

\section{Urceolaria.}

Thallus crustose, usually quite thick and areolate, the areoles becoming distinctly convex or warty in some species. The prevailing color of the upper surface is gray, lower surface whitish. The alga are no doubt Protococcus; they usually occur in groups of six to twelve, thus differing from the usual forms which occur singly. 
The apothecia are quite small, globose, and are immersed in the thallus, opening by a pore. The hypothecium is usually dark. The genus should perhaps be placed with the Verrucariacea, since its apothecial characters point toward such a relationship.

The spores, when mature, are multilocular and dark. The immature spores are simple, colorless, and larger than the mature spores. It should also be borne in mind that the mature spores are often quite structureless.

Most of the species are northern in their range. They occur upon rocks, a few upon the soil.

1. Urceolaria actinostoma. Thallus comparatively thin, areolate, areoles never convex; gray to dark-gray. Apothecia small, immersed in somewhat convex areoles. Disk dark. Spores dark, multilocular, $14 \mu \times 7.5 \mu$.

2. Urceolaria scruposa. Thallus quite thick, areolate, fissured, gray. Apothecia immersed in somewhat elevated areoles. Disk somewhat darker than thallus. Spores dark-brown, elliptical, multilocular, $21 \mu \times 9 \mu$.

An orange coloring substance is obtained from the Urceolarias; it was used in dyeing woollen goods.

\section{Hamatomma.}

This genus is usually combined with Lecanora, though its spore-characters are wholly different. The thallus is crustose but very thick; sometimes covered over by a soredial powder. The color is gray tinged with green, or sometimes yellowish.

The apothecia vary from medium to quite large; 
they are usually discoid, irregular in outline, sessile or adnate upon the thallus. The disk is usually flattened, margin only slightly elevated. Hypothecium is colorless.

The spores are long, acicular, pointed toward one end, curved, undulate or twisterl, colorless, five to seven-celled. The spores are very characteristic, and when once seen are not likely to be mistaken ; they resemble most nearly those of Bacidia.

The species occur upon rock, trees, earth, logs, etc. They are somewhat northern in their range and prefer mountainous districts.

1. Hamatomma punicea. Thallus areolate to warty, greenish-gray. A pothecia small. Disk bright reddishbrown. Spores acicular, colorless, five to seven-celled, $30 \mu \times 3 \mu$.

2. Hamatomma ochrophaa. 'Thallus thick, warty, not fissurerl, grayish-green, white interually. A pothecia small to medium. Disk pale to dark brown. Spores colorless, indistinctly five to seven-celled, curved, $49 \mu \times 4.5 \mu$.

3. Hamatomma ventosa. Thallus very thick, deeply fissured ; surface areolate, warty; yellowish-green to dirty green above, white within and beneath. Apothecia medium to large, spreading, margin irregular in outline and somewhat lobulate. Disk reddish-brown. Spores five to seven-celled, colorless, curved, thinner toward one end, $37 \mu \times 2 \mu$.

The so-called Lacidea parasitica (perhaps a fungus) is often parasitic upon this plant. H. ventosa is closely related to the foreign Lecanora esculenta already men- 
tioned in the historical review. The Hamatommas have also found a place in the dyeing industries.

\section{Lecanora.}

The thallus varies from crustose to somewhat foliose. It is highly probable that the Parmelias are the direct descendants of the Lecanoras. The amateur is likely to confuse the Lecanoras and Biatoras, since they resemble each other in their general characters, especially the spore-characters. The foliose forms have numerous small, more or less plicate, lobes which are somewhat ascending and bear numerous rhizoids. Color of the thallus varies from light-green to dark.

The apothecia are generally plentiful; as compared with the apothecia of the Biatoras they are quite large. They are discoid, sessile, not immersed; margin extending somewhat above the brown to nearly black disk. Hypothecium colorless.

The spores are simple, colorless, elliptical, somewhat variable in size and form.

The Lecanoras occur upon bark and rock and have a wide range.

1. Lecanora lacustris. Thallus very thin, uniformly spreading, indistinctly areolate; reddish-brown. Apothecia small, scattering, partially immersed, margin somewhat raised. Disk reddish-brown to dark. Spores rarely mature.

2. Lecanora orosthea. Thallus thin, powdery to finely granular, pale sulphur color. Apothecia of medium size, margin barely raised, somewhat crenate. Disk pale-brown. Spores ovoid, colorless, $14 \mu \times 7.5 \mu$. 


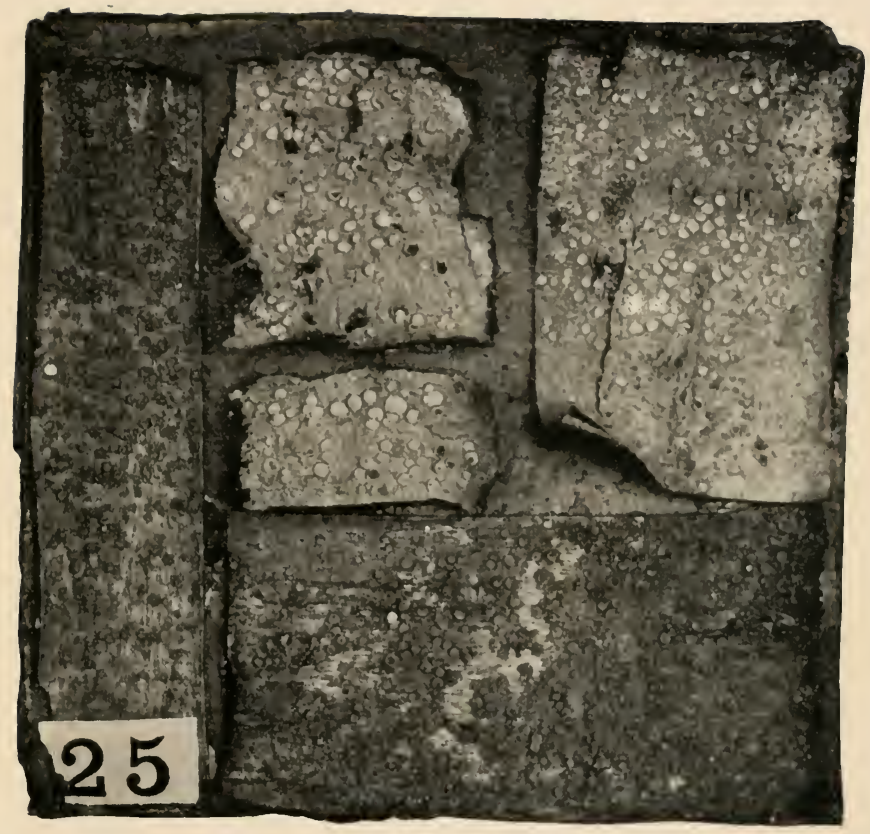

PI.ATE Id. Crustose Types. From the collection of $X$. Y. Clark in the lorbarimm of the ('alifornia Acalemy of sieience. Leconuma prellidu. 

3. Lecanora Bockii. Thallus granular, somewhat areolate; dark. Apothecia small, slightly raised above thallus. Disk somewhat lighter in color than thallus. Spores rare, typical.

4. Lecanora calcarea. Thallus areolate, dark. Apothecia small, usually numerous, irregular, margin slightly raised above the brown to dark-brown disk. Spores elongated, slightly curved, $15.5 \mu \times 4 \mu$.

5. Lecanora Hageni. Thallus granular to indistinctly warty, gray to dark. Apothecia small, numerous ; margin entire, elevated ; light-gray. Disk reddishbrown to dark-brown. Spores ovoid or elliptical, 7.5 $\mu$ $\times 4.5 \mu$.

Nos. 4 and 5 are generally associated with species of Placodium.

6. Lecanora pallida. Thallus uniform, areolate, rarely granular and warty, pale color. Apothecia medium to large, somewhat lobulate or folded, elevated margin. Disk flattened, pale-brown to brown. Spores typical, $12 \mu \times 6 \mu$.

7. Lecanora Cupressi. Thallus granular to warty, pale-green. Apothecia small to medium, numerous, margin crenulate. Disk pale yellowish-brown. Spores typical, slightly curved, $13 \mu \times 4.5 \mu$.

8. Lecanora varia. Thallus much as in $L$. Cupressi, more distinctly warty. Apothecia as in No. 7, margin more elevated; spores the same.

Nos. 7 and 8 are evidently closely related, if not identical. L. varia is quite common and has a wide range. Saussure and Agassiz collected specimens on the summits of the Alps. 
9. Lecanora subfusca. Thallus rudimentary to warty or areolate, light-gray to light-brown. Apothecia small to medium, margin entire and somewhat flexed, slightly elevated. Disk flattened to convex, reddish-brown to black. Spores typical, $9 \mu \times 6 \mu$.

It is perhaps likely that most authors combine several species in the above. It is of common occurrence and has a wide range.

10. Lecanora atra. Thallus evenly spreading, becoming warty and areolate, gray. Apothecia medium, margin slightly raised above the flattened black disk. Spores typical, $12 \mu \times 6 \mu$.

This lichen has been used in dyeing.

11. Lecanora pallescens. Thallus rather thin, more or less ridged or chinky, according to the nature of the substratum (bark), surface smooth; pale-gray. Apothecia medium to large, margin somewhat rugose. Disk pale-brown. Spores large, typical, $36 \mu \times 21 \mu$.

"This lichen yielded the 'Orseille d'Auvergne.' The pigment was prepared chiefly at St. Flour and Limoges, and the lichen was collected by the peasantry of Auvergne, Limousin, Languedoc, Provence, Lyons and other districts of southern France. Manufacturers distinguished two varieties, white and gray, depending chiefly on the maturity and purity of the plant, the latter being preferred. Under the name of ' Light Crottle' it has been much used by the Scotch Highlanders to yield an orange or reddish dye for woollen goods; and as the common 'Crab's-eye Lichen' it 
appears to have been gathered in the North of England." - Lindsay.

12. Lecanora cenisia. Thallus thick and readily removed from substratum (rock), consisting of large confluent warts, light-gray. Apothecia medium to large, attached by a narrow neck; crenate, margin elevated above the dark disk. Spores typical, $12 \mu \times 8 \mu$.

18. Lecanora muralis. Thallus lobed at the margin, areolate toward the interior, sometimes of scattered entire lobes. Apothecia small. Disk somewhat convex, brown. Spores typical, $10.5 \mu \times 5 \mu$.

14. Lecanora tartarea. Thallus thick, of imbricate ascending branches, sometimes becoming semi-foliose or semi-fruticose, light-gray to grayish-green. Apothecia medium to large, margin somewhat rugose. Disk brown to reddish-brown. Spores large, typical, $52 \mu \times 21 \mu$.

This lichen was employed to make litmus and to produce a purple for dyeing woollen goods and nowhere, perhaps, used more extensively than in England. The lichen was sold at about eighty cents per stone of twenty-two pounds. The same rocks were scraped once every five years.

15. Lecanora rubina. Thallus-lobes ascending showing a fruticose tendency, grayish-green above and toward the apex, brown and dark below and toward the base. Apothecia medium to large; margin crenate and raised somewhat above the pale yellowishbrown disk. Spores typical, $7.5 \mu \times 4.5 \mu$. 


\section{Acarospora.}

This genus is by some authors placed with Lecanora. The thallus is crustose and rudimentary in the lower forms; in the higher forms it becomes foliose and lobed, especially toward the margin. In many respects the thallus resembles that of Hamatomma. Color dark in the lower forms and yellowish in some of the higher forms. Algæ are Pleurococcus vulgaris as in Endocarpon.

The apothecia are immersed in the thallus, variable in size and form. The disk varies from orbicular to irregularly lobate or. crenate; it is usually flattened, more rarely convex, or margin slightly elevated. Color of disk varies from dark to yellowish. The spore-sacs are cylindrical, and each one contains several hurdred very minute simple colorless spores which are held together by a gelatinous substance, so that the entire contents may be ejected or forced out.

The Acarospora are quite widely distributed and occur principally upon rock (granite) and sandy soil.

1. Acarospora privigna. Thallus rudimentary, yellowish to dark. Apothecia small, orbicular, scattered; margin slightly elevated above the dark flat disk. Spores elliptical, typical, $3 \mu \times 1.5 \mu$.

2. Acarospora cervina. Thallus areolate, dark to nearly black. Apothecia barely raised above the thallus, often remaining after the thallus is worn away, irregular in outline. Disk dark. Spores closely adherent owing to a gelatinous substance, typical. 
This plant is often found associated with species of Placodium.

3. Acarospora dealbata. Thallus of white scattered warts of considerable thickness. A pothecia immersed, one in each areole. Disk black. Spores typical.

\section{Speerschneidera.}

This genus, as represented by the single species, is closely related to Parmelia. The thallus is foliose, much branched, with lobes of uniform wilth. There is also a slight fruticose tendency. The apothecia are rather small, sessile upon the upper surface of the thallus. Disk light-brown. The spores are small, colorless, elliptical and distinctly two-celled.

1. Speerschneidera euploca. Thallus much branched, lobes slender, of uniform width and somewhat ascending, gray. Apothecia cup-shaped, sessile. Disk lightbrown. Spores typical.

This is the only species reported from the United States, it is southern in its range. The specimens which came to my notice were associated with species of Collema. It is a small plant, but has a very characteristic appearance.

\section{Parmelia.}

It is highly probable that this genus is phylogenetically derived from Lecanora, as seems evident from a comparison of the higher Lecanoras and the lower Parmelias. The exact relationship of the Hamatommas, Acarosporas and Speerschneidera is not known.

The thallus of the Parmelias is foliose, large, distinctly branched and lobed. It is held to the substra- 
tum by black rhizoids. White or light colored soralia occur in a number of the species. As compared with the Physcias the thallus is larger and less distinctly ash-gray, The color varies from gray and brown tinged with green and bluish-green to brown and dark.

The apothecia are distinctly cup-shaped and vary from medium to very large. It shows perhaps the highest development of the thalline type. It is in reality a secondary thallus having a combined radial and centric structure. The disk is generally brown.

The spores are simple, colorless, elliptical, often bearing oil-globules; the spore-wall is thin.

The Parmelias are common everywhere, occurring upon trees, rocks, stone walls, fences, roofs of old buildings, etc. Some acquire considerable dimensions, reaching three or four feet in diameter. In many cases there is continued marginal growth while the central portion dies away, thus producing a semblance to the "fairy rings" of toad-stools.

1. Parmelia conspersa. Thallus quite large, growth radial, branched with lobes imbricate (overlapping); upper surface usually smooth, sometimes bearing warty outgrowths, soralia rare, brownish to greenish; lower surface brown with numerous rhizoids. Apothecia small to medium, margin entire. Disk olive-brown. Spores typical, $13 \mu \times 9 \mu$.

2. Parmelia multisporum n. sp. Thallus of medium size, lobed, adnate to substratum; upper surface smooth and olive color. Apothecia numerous. Disk olive to chestnut-brown; thecæ bearing from 50 to 100 colorless elliptical spores, $5 \mu \times 4 \mu$. 
This species may be identical with $P$. taniata, though it differs somewliat in the characters of the thallus. In the latter the spores are also more numerous (100 or more) and smaller $(2.5 \mu \times 1 \mu)$. So far as could be determined $P$. multisporum is a western species, occurring in Washington, Idaho and Utah. The material which came to notice was labelled $P$. olivacea, which has the same general characters but bears only the usual number of spores in each spore-sac (8).

3. Parmelia caperata. Thallus from medium to large, of typical radial growth, branching, lobes rounded, more or less crenulate, and margins turned slightly upward ; upper surface rugosely folded, bluishgreen, soralia upon the ridges of the folds; lower surface black, brown near margin. Apothecia few or wanting, medium size, margin often covered with soralia. Disk chestuut-brown. Spores typical, $25 \mu \times 12 \mu$.

In the north of Ireland and on the Isle of Man this lichen is known as "Stone Crottles," and was extensively used by the peasantry for dyeing woollen fabrics a lemon color. The lichen has a wide range, occurring throughout the United States, South America, Europe and other countries.

4. Parmelia plyysodes. Thallus medium to large, much branched, lobes linear and somewhat ascending; tips inflated, upper surface generally bearing numerous spermagonia, soralia sumetimes present, brownish to ash-gray; lower surface black, brownish toward tips. Apothecia usually present. Disk chestnut-brown. Spores small, typical, $6 \mu \times 4.5 \mu$. 
This species is the "dark crottle" of the Scottish peasantry by whom it was used to dye woollen stuffs brown. It was also used as an article of diet and in the manufacture of a gum similar to gum-arebic.

5. Parmelia saxatilis. Thallus medium to large, lobes narrowed, terminal ones small; upper surface smooth, reticulately rugose, sometimes brownish, warty (isidioid) outgrowths covering entire thallus, greenishgray; lower surface black, with numerous black rhizoids. Apothecia medium, sometimes wanting. Disk brown. Spores typical, $11 \mu \times 9 \mu$.

This is the "Sten-laf" of Sweden and Norway, where it was used to dye thread, yarn, etc., a brown or reddish-brown color. In Scotland it is one of the most common "crottles" and is also known as "Staneraw" or "Staney-rag." Not only do the peasantry use it but it would appear upon the evidence of the border ballads that the border fairies were dressed in tunics dyed with this lichen.

"Like the feld-elfin of the Saxons, the usual dress of the fairies is green; though on the moors they have been sometimes observed in heath-brown, or in weeds dyed with 'Stane-raw' or 'lichen.' This lichen was also used in medicine as an astringent; by the ancients it appears to have enjoyed a celebrity as a sovereign remedy for epilepsy and the plague." - Lindsay.

6. Parmelia Borreri. Thallus large, lobes rounded, with crenulate margin, bearing a few black cilia ; upper surface bearing numerous warty (isidioid) outgrowths, bluish-green color, no soralia; lower surface lightbrown to whitish with black rhizoids. Apothecia 

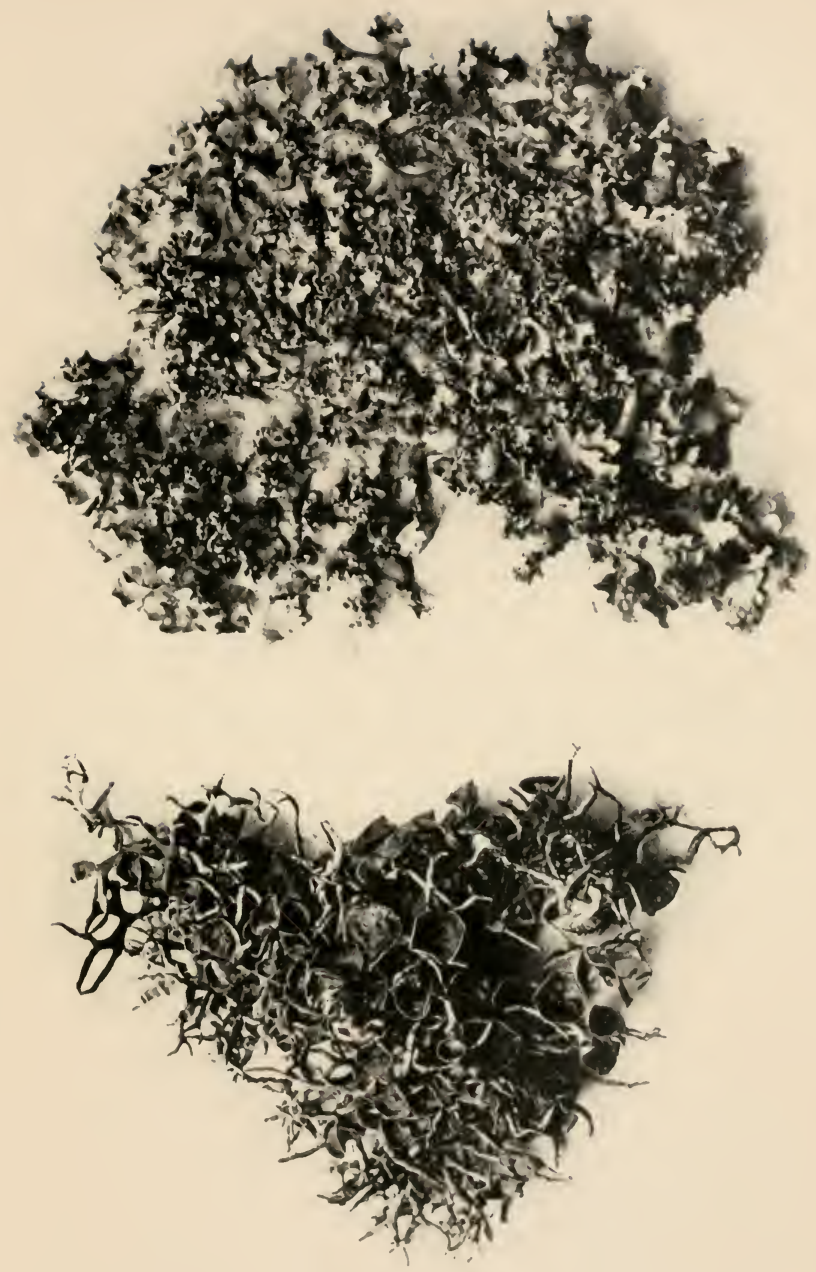

PLATE III. Fuliuse Tyjes, thallus dividerl. From Mt.

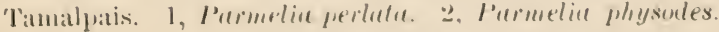
While the latter is elassed as follose, it shows a derided truticose tendency. 

few or none. Disk brown. Spores few, typical, $11 \mu \times 8.5 \mu$.

7. Parmelia perforata. Thallus large, lobes large, rounded, margin somewhat crenulate, few or no soralia, grayish-green, spermagonia usually numerous; lower surface black, with long black rhizoids. Apothecia large, bottom of cup perforate. Disk brown. Spores typical, $17 \mu \times 10 \mu$,

8. Parmelia latissima. Thallus large, rounded lobes, with crenate margin, and bearing white soralia, lightgreen or grayish-green above; lower surface black, becoming brown toward margin. Apothecia rare or wanting. Disk brown. Spores typical, $23.5 \mu \times 9.5 \mu$.

This is evidently a tropical lichen. It is often confused with the following species.

9. Parmelia perlata. Thallus large, lobes rounded, crenate, bearing white soralia, grayish-green; lower surface as in $P$. latissima. Apothecia usually wanting. Spores typical, $13 \mu \times 9.5 \mu$.

This lichen yields a fine orchill. It was at one time imported into England from the Canary Islands as "Canary rock-moss."

\section{Cetraria.}

This genus is perhaps phylogenetically derived from some Parmelioid type or types. The thallus varies from foliose to typically fruticose, but in all cases the lobes are flattened and broad. The amateur will no doubt confound some species with Parmelia. In general, however, the thallus is more brittle and different in color; brown predominating. In some 
species there is a yellow coloration. Cilia are frequently present; soralia are comparatively rare.

The apothecia are of medium size, discoid, usually less markedly cup-shaped than in Parmelia. Disk chestnut-brown, shining, margin somewhat crenate or torn. The spores are simple, elliptical and colorless, somewhat smaller than in Parmelia.

Most of the Cetrarias are northern, occurring upon trees and rocks.

1. Cetraria Fahlunensis. Thallus foliose, much branched, smooth, somewhat ascending, marginal lobes olive-brown to nearly black above; dark beneath with numerous rhizoids. Apothecia few, medium to large, thin. Disk chestnut-brown, smooth. Spores typical, $8 \mu \times 6.5 \mu$.

This lichen furnishes a red (vermilion) dye.

2. Cetraria ciliaris. Thallus foliose and much branched, lobes somewhat ascending and ciliate, smooth; ash-gray tinged with bluish-green above, light-brown beneath, rhizoids few. Apothecia medium to large, margin crenulate or torn. Disk chestnutbrown, smooth. Spores typical, spherical, $6 \mu$.

3. Cetraria jun perina. Thallus foliose, medium size, branched, terminal lobes ascending, lacerate; straw color on both surfaces. Apothecia of medium size, margin crenate. Disk chestuut-brown. Spores typical, $8 \mu \times 6.5 \mu$.

Upon boiling in water this lichen yields a yellow coloring-matter which was much used in Sweden for dyeing home-made cloth fabrics and Easter eggs. With Placodium murorum it was at one time highly rec- 
ommended for the cure of jaundice (according to the similia similibus curantur principle of homeopaths).

4. Cetraria lacunosa. Thallus foliose, rather large, upper surface reticulate, bluish-green tinged with gray; lower surface brownish. Apothecia medium. Disk chestnut-brown, base sometimes perforate, as in Parmelia perforata. Spores typical, $7.5 \mu \times 5.5 \mu$.

This species is often confounded with $C$. ciliaris.

5. Cetraria cucullata. Thallus fruticose, terminal lobes rather finely divided; straw color, darker toward base. Apothecia large, attached to the lower surface of turned terminal lobes. Disk chestnut-brown. Spores typical, $9.5 \mu \times 5.5 \mu$.

6. Cetraria Islandica. Thallus fruticose, lobes comparatively narrow, rolled, rigid, erect; margin lined with rigid cilia; upper surface chestnut-brown, lower surface somewhat lighter. Apothecia medium. Disk chestnut-brown. Spores typical.

This lichen, commonly known as "Iceland moss," has enjoyed great popularity as a medicinal substance and as an article of diet. It is still extensively used as food for convalescents and those having weak stomachs. Icelanders powder it and use it as flour. In Scandinavia it is used as fodder for cattle. It yields a brown color which was once much used for dyeing woollen goods.

According to the United States Dispensatory, Iceland moss is demulcent, nutritious and tonic, well calculated for affections of the mucous membranes of the lungs and bowels in which the local disease is associated with debility of the digestive organs, or the 
general system. The plant has, however, no active curative property, and is fast going into disuse as a medicine.

\section{Ramalina.}

In this genus the thallus is typically fruticose, the lobes being flattened. In the majority of species the surface is smooth. The length of the thallus varies greatly; in the smallest species an inch or less to several feet in the largest. The branches are strapshaped, and in a few species tend to become cylindrical. Color varies from greenish to gray or even brown. Large soralia occur on some species.

The apothecia vary from rather small to medium in size. They are flattened or cup-shaped, lateral, occurring either along the margin or upon the flat surface. Disk pale brown. Spores are colorless, elliptical, twocelled.

The Ramalinas occur upon trees and rocks; they are not plentiful.

1. Ramalina minuscula. Thallus minute, half an inch or less in height, branches canaliculate; terminal branches very short; soralia sometimes present; color light-gray. Apothecia and spores not seen.

2. Ramalina calicaris. 'Thallus one or two inches in height; lobes comparatively thin and broad, somewhat canaliculate and slightly reticulate, green. Apothecia of medium size, terminal tendency, somewhat cup-shaped. Disk light-brown. Spores typical, not curved, $10.5 \mu \times 5.5 \mu$.

Most authors recognize a number of varieties, some of which no doubt deserve the rank of species. $R$. 
calicaris has a wide range and usually occurs upon trees (oak in particular) ; it is also said to occur upon rock. The species has been made use of as a gum in calico-printing, in the preparation of "parchment" andpasteboard, and in the manufacture of hair-powders. The soralia-bearing specimens (mealy Ramalina calicaris) have been highly recommended as an article of diet. It has also found a use in the treatment of chilblains and chapped hands. A variety obtained from Teneriffe yields a yellow dye. According to another authority the species yields a rich red dye equal to that obtained from Rocella tinctoria which was used in dyeing silken and woollen goods. The plant was said to have brought $\$ 5,000$ per ton in England.

3. Ramalina homalea. Thallus large, rather sparingly branched, lobes ribbon-like, thick, rigid, smooth, not canaliculate; gray to brown. Apothecia medium, with a terminal tendency, sometimes distinctly cupshaped. Disk about the same color as the thallus. Spores typical, somewhat curved, $15 \mu \times 5 \mu$.

This lichen is essentially southern, and occurs upon rocks. It is no doubt rich in coloring properties.

4. Ramalina ceruchis. Thallus rather small, sparingly brauched, lobes somewhat flattened to nearly cylindrical, gray; smooth, becoming dark spotted. Apothecia medium, cup-shaped. Disk about the same color as thallus. Spores typical, not curved, $15 \mu \times 4 \mu$.

5. Ramalina polymorpha. Thallus long, much branched; lobes narrow, flattened, bearing large soralia. Apothecia rare. Spores, $14 \mu \times 5 \mu$. 
6. Ramalina rigida. Thallus long and much branched; lobes very slender, flattened, gray. Apothecia rather small, lateral, not cup-shaped. Disk somewhat convex, color of thallus. Spores typical, oblong, not curved, $21 \mu \times 4 \mu$.

7. Ramalina reticulata. Thallus very long (several feet), pendulous, much branched; lobes slender, flattened, reticulately perforate. Apothecia lateral, small. Disk convex and of the same color as the thallus. Spores typical, curved, $14 \mu \times 7 \mu$.

This lichen is at once recognized by the reticulate perforations of some of the lobes, or perhaps more correctly the reticulate branching of certain portions. It is southern and occurs upon trees.

\section{Rocella.}

This is a typically fruticose genus. The thallus is sparingly branched, lobes flattened, rigid, thick, not canaliculate; edges rounded. Color gray to somewhat purplish. Large discoid soralia frequently occur along the margin of the lobes. The apothecia are small, marginal, not terminal, and characterized by a black hypothecium, a characteristic not found in any other genera of the family. Disk flattened, dark to black. The algæ are Chroolepus. These two characters are in contrast to the other generic groups of the family and seem to indicate that the genus is perhaps misplaced. As has already been indicated, Reinke and others place the group with the Graphidacea. The gross characters, however, indicate a relationship to Ramalina. 


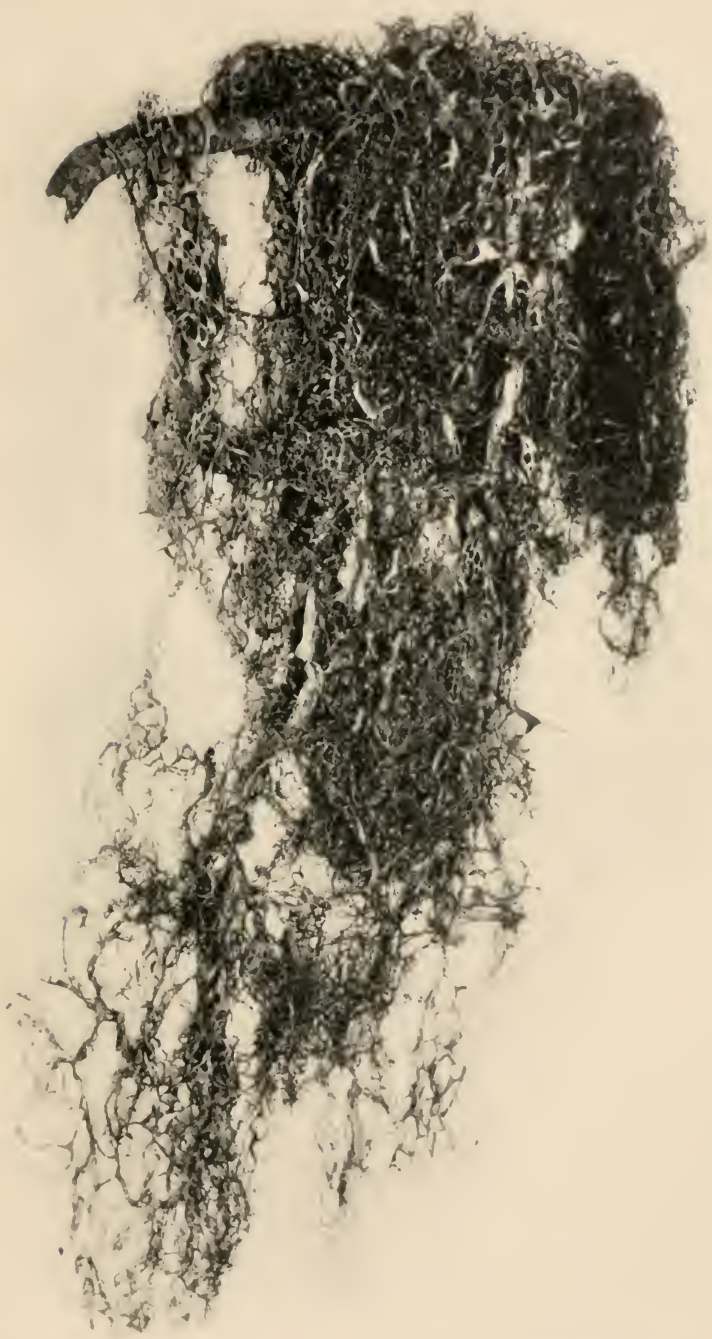

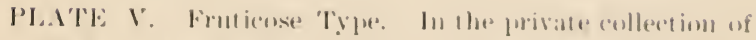
R. S. Ciray, Maklamu, ('alif. From limlwuml, (allif.

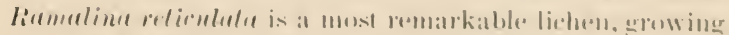
in larere loner tufis. Gften contused with I sneal borlutu 

The Rocellas are essentially tropical, occurring on rock along the sea-coast. Less frequently they occur upon trees. The American specimens are found principally in Lower California.

1. Rocella tinctoria. Thallus quite large, sparingly branched, lobes long, usually flattened, but often becoming rounded, gray to purplish. Apothecia comparatively rare, lateral, medium, Disk flattened to slightly convex, black. Lateral white soralia. Spores colorless, oblong, four-celled, $20 \mu \times 7 \mu$.

This lichen occurs plentifully along the Mediterranean coast. It occurs, in fact, in all tropical countries. Its uses as a dyeing agent have already been referred to. It also found a use in the treatment of coughs and in diseases of the kidneys. For the latter purpose it was largely collected from the island of Mauritius.

2. Rocella leucophaa. Thallus large, branching, lobes flattened, gray. Apothecia lateral, medium size. Disk flattened, black. Lateral white soralia. Spores typical, $21 \mu \times 8 \mu$.

The occurrence and use of this lichen are similar to those of $R$. tinctoria.

\section{Evernia.}

There seems to be considerable uncertainty as to the limitation of this genus. As represented by the two types given below, there is certainly a wide difference in anatomical characters.

The thallus is generally fruticose, large; the branches are irregularly angular and not distinctly flattened. The surface of the thallus has the appearance of hav- 
ing been besprinkled with a mealy substance. Color varies from yellowish to grayish-green or bluish-gray. Apothecia, when present, are quite large, discoid, often bearing filiform thalloid branches. Disk of a different color from the thallus. The spores are small, simple, oval, colorless; resembling those of Cetraria.

1. Evernia furfuracea. Thallus large, much branched, foliose, but pendulous upon branches of trees; bluish-green, tinged with gray; channelled below, light-gray. Usually sterile. Apothecia not seen.

This lichen is striking in appearance and in the eastern states occurs almost wholly upon pine trees in mountainous districts. It is a handsome, soft, pliable plant, which is only very loosely attached to the branches of the tree. Some authors place it in the group Physcia.

This species was at one time highly recommended as a substitute for quinine. It yields a red dye. The Egyptians at one time employed it in the making of bread and in the preparation of hair-powiters.

2. Evernia vulpina. Thallus large, typically fruticose, branches angular, ridged, thickness of branches decreasing toward the top; lemon color. Apothecia very large, terminal tendency, margin and lower surface bearing thalloid filaments. Disk brown, concave. Spores colorless, elliptical, simple, $7.5 \mu \times 5.5 \mu$.

This is the noted "Ulf-mossa" (Wolf's moss) of the Swedes. It was so named from the popular belief that the plant was poisonous to wolves. The lichen was powdered and mixed with powdered glass; the 


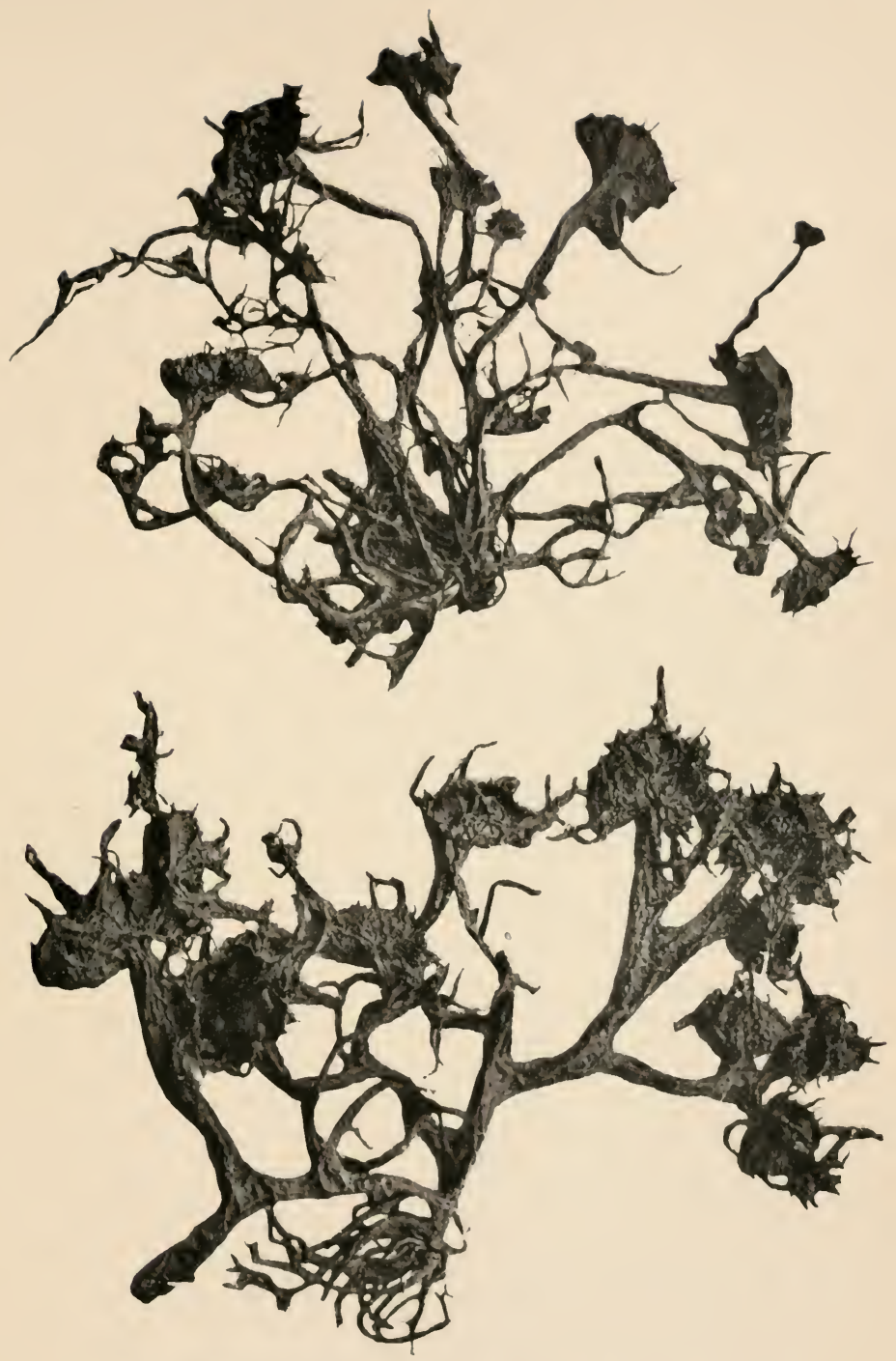

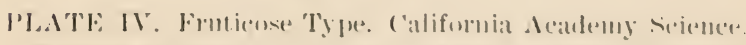

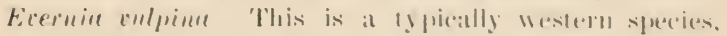

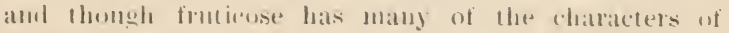
foliose lichens. 

mixture was then smeared over some dear animal placed in a locality frequented by the wolves. It was also used to dye woollen goods a bright yellow.

This is the most showy and largest lichen found along the Pacific coast, where it usually occurs fertile; the specimens found in the interior and eastern states are small and always sterile.

\section{Alectoria.}

This genus has only a few representatives. The thallus is typically fruticose, long and pendulous. At the joints the thallus is somewhat flattened, otherwise the branches are cylindrical. There is a semblance to Usnea, but the surface is smoother and the apothecia are smaller. The color varies from light to brown and nearly black. Oval soralia are ten present. The apothecia are few, sessile, small to medium. Disk flattened or convex. Spores colorless to dark, simple, two to four in each spore-sac, large, with thick outer spore-wall. The spores remain colorless until maturity, when the cell-contents become dark. Oil-globules are frequently present in the spores.

The Alectorias occur in arctic regions and upon high mountains. They grow upon coniferous trees.

1. Alectoria sarmentosa. Thallus long, pendulous, branched; flattened at joints; straw color; surface smooth or bearing oval soralia. Apothecia few, medium, lateral. Disk light color to brown. Spores typical, $32 \mu \times 17.5 \mu$.

This plant is usually described as $A$. ochroleuca var. sarmentosa; also as C.ornicularia ochroleuca. 


\section{Bryopogon.}

This group is evidently closely related to Alectoria, as is indicated by the histological characters. The thallus is long, pendulous, typically fruticose; much branched, lobes cylindrical, only slightly compressed at the joints. In a transverse section of the thallus it is found to be nearly hollow in the middle, no central core being present (also true of Alectoria). Color black. Apothecia few, small to medium, lateral. Disk dark, entire, somewhat convex. Spores are small, simple, colorless, eight in each spore-sac (normal number). It must also be kept in mind that the Alectorias as well as Bryopogons are frequently sterile.

The species occur upon rock, soil, trees and ferns in the higher altitudes and latitudes.

1. Bryopogon Oregana. Thallus comparatively small, more or less erect, much branched, comparatively rigid, black. Apothecia medium, comparatively numerous. Disk dark to black. Spores typical, $6 \mu$ $\times 4.5 \mu$.

2. Bryopogon jubata. Thallus long, pendulous, much branched, branches long and entangled, sometimes bearing soralia, brown to black. Apothecia very few or wanting, lateral. Disk of same color as thallus. Spores typical of the genus.

This is without doubt a most striking lichen. In its perfect development it resembles a tuft of woman's tresses. Because of such a resemblance it has been designated as "tree or rock hair." It has also been called "horse-tail lichen," but this name is less apt 
since the thallus is less rigid than the hair of the horse's tail.

B. jubata, and perhaps also other species, yields a red dye. Reindeers feed upon it when Cladonia rangiferina is not obtainable. Laplanders are said to cut down the trees upon which it grows so that the reiudeer may have more ready access to the lichen.

\section{Usnea.}

Thallus fruticose, pendulous, large, much branched; lobes cylindrical, or rarely flattened, decreasing in size in an acropetal (toward apex) direction. Maiu branch quite thick and rigid. The surface is less smooth than in the thalli of Alectoria and Bryopogon; often it is circularly fissured. Soralia are quite rare. Upon making a transverse section of the thallus it is found to contain a rather firm central core of longitudinal hyphæ. The prevailing colors of the thallus are grayish-green, pale brownish-green or straw color. The apothecia are very variable in size, lateral to terminal. Spores small, simple, elliptical, colorless.

The Usneas are somewhat northern in their range. They occur upon trees in the higher altitudes. Considerable confusion exists as to the limitations of some species and varieties, as, for example, Usnea barbata and its real or imaginary varieties. The following are the more common species irrespective of varieties.

1. Usnea linearis. Thallus medium, of several main branches, bearing numerous long, slender, cylindrical branches; greenish-gray. No fertile specimens have come to notice. 
By many collectors this plant is designated as $U$. barbata. It occurs on trees in proximity to U. barbata.

2. Usnea barbata. Thallus medium, much branched; branches comparatively rigid, transversely fissured, especially the larger main branches, greenish-gray. Apothecia numerous, very large, bearing filiform branches. Disk somewhat concave, light-brown color. Spores typical, $8 \mu \times 5 \mu$.

This is the "beard-moss" or "tree-moss" of poets - the "idle moss" of Shakespeare. It is a cosmopolitan plant; it occurs plentifully in the arctic regions as well as in the tropics. In some countries it is eaten by wild animals or is collected and preserved as fodder for domestic animals. Bertram states that the Pennsylvanians prepared from it an orange dye, and Humboldt states that the South Americans used it for dyeing purposes. In the past ages it enjoyed an extensive use as a remedial agent. It was used as an astrigent, tonic, diuretic; it was highly recommended for whooping-cough, and as an anodyne. It formed the basis of hair-powders and perfumes and was thought serviceable in the preparation of explosives. Boiled in beer it was said to cure catarrh and dropsy. The Laplanders used it in the treatment of scald head, and scrofula of children.

3. Usnea longissima. Thallus much elongated, branched, lobes somewhat flattened, greenish-gray. Apothecia rare or wanting. Spores typical, $9 \mu \times 5 \mu$.

The thallus is much longer than in $U$. barbata, and also more slender and pendulous. It occurs mostly upon trees on high mountains. 


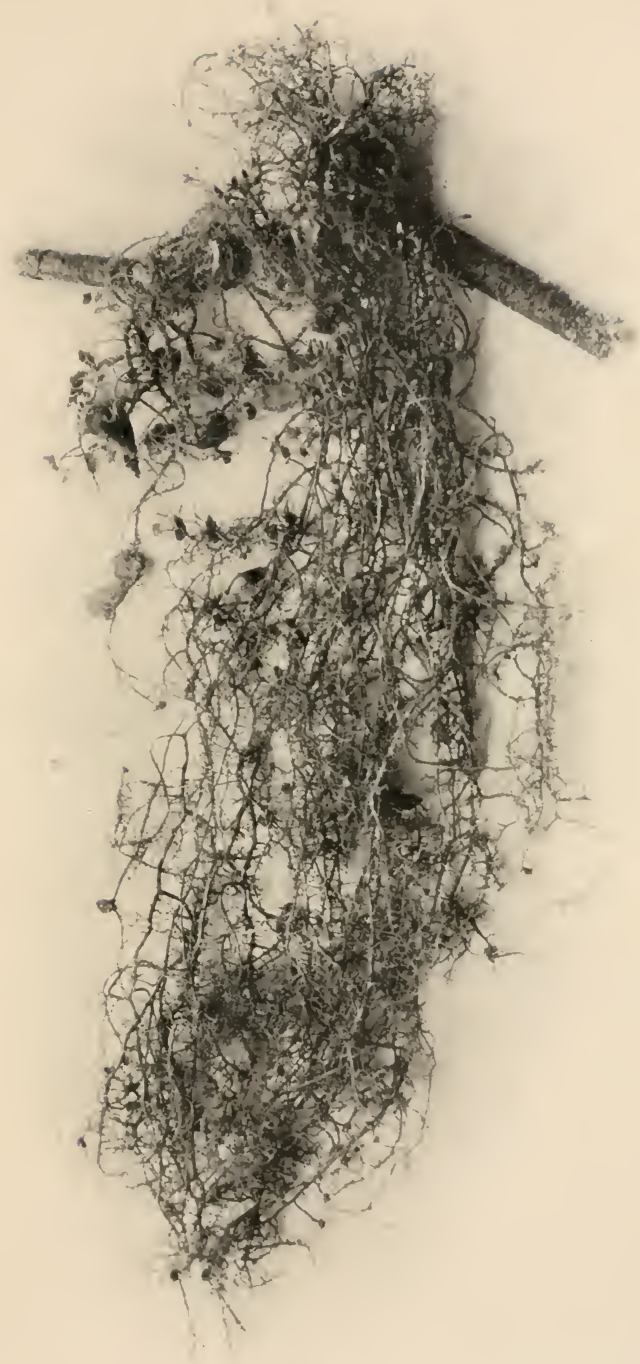

PLATE VI. Fruticose Type. Redwood Canyon, Marin Co., California. Usnea barbata, the familiar ". beard moss." 



\section{VERRUCARIACEAE.}

The representatives of this family are characterized by small globose apothecia, which are either immersed in the substratum (bark or rock) or in the thallus (Dermatocarpon and Endocarpon). In the majority of genera the thallus is crustose, even wholly hypophlœodal or hypolithic. Another characteristic of the family is the indistinct, slender, gelatinized paraphyses.

With the exception of Endocarpon the members of the family are insignificant in appearance; in fact, some are very doubtful lichens, as, for example, most of the Pyrenulas and some species of Trypethelium.

Two algal types exist in this family: Chroolepus occurs in the genera from Trypethelium to Verrucaria, Pleurococcus occurs in Verrucaria, Dermatocarpon and Endocarpon. It must, however, be born in mind that the algal symbiont may vary in different individuals of the same species. This change in symbionts requires further study.

\section{KEY TO THE GENERA.}

Crustose thallus.

Thallus scarcely visible, mostly hypophlœodal.

Spores six to eight-celled, colorless. 1. Trypethelium.

Spores four-celled, brown . . . . 2. Pyrenula.

Spores many-celled, colorless . . 3. Conotrema.

Spores multilocular, colorless.

Spore-wall normal . . . . 4. Thelotrema.

Spore-wall thick . . . . . 5. Gyrostomum.

Thallus visible, mostly epiphlœodal or epilithic.

Spores simple, colorless.

Medium size . . . . . 6. Verrucaria.

Very large . . . . . . . \%. Pertusaria.

Foliose thallus, entire; spores colorless.

Spores multilocular: thallus minute . S. Dermatocarpon. Spores simple; thallus large . . . 9. Endocarpon. 


\section{Trypethelium.}

The thallus is hypophloedal during its entire existence. It consists simply of a deficient network of hyphæenclosing a few algæ (Chroolepus). The bark over the apothecia and thallus is smooth and of it rusty-red color which gradually fades into brownish or greenish.

The apothecia are likewise hypophloodol, and occur in clusters of from five to forty. Each apothecium is, however, independent of its neighbors, and may be considered as an individual of the colony. As the apothecia grow, they push up the superimposed bark until it forms a more or less irregular elevation. The spores escape through minute apical pores.

The spores are normally colorless and eight-celled, spindle-shaped; the plasmic masses diamond-shaped.

The genus is essentially southern. The representatives occur upon trees. Some authors combine it with Pyrenula.

1. Trypethelium virens. Bark above thallus smooth, light-brown to pale-green. Apothecial colonies consist of from ten to forty minute apothecia. Perithecium black. Spores colorless, six to eight-celled, $42 \mu \times 10 \mu$.

Bark is tinged reddish or rusty brown, over and about the apothecia. Nearly all of the so-called species of Trypethelium require further study.

\section{Pyrenula.}

This is another lowly-organized lichen-genus. The thallus as well as the apothecia are hypophloodal, and 
morphologically resemble similar structures of the preceding genus. Sometimes the apothecia occur singly, but they also occur in colonies. The perithecium is black. The spores are usually colored dark, four-celled, otherwise resembling those of Trypethelium.

The representatives of this genus are mostly southern in their range. They occur upon the smoother barks. In many the thallus is very rudimentary, so that the algæ (Chroolepus) can only be found after careful search.

1. Pyrenula aspistea. Bark over thallus brown, smooth. Apothecia small, numerous, black. Spores typical, constricted at transverse septa, $17 \mu \times 8.5 \mu$.

2. Pyrenulu nitida. Bark over thallus greenish or yellowish-brown. Apothecia larger, fewer, and more scattered than in $P$. aspistea, black. Spores typical, not constricted, $14 \mu \times 7.5 \mu$.

\section{Conotrema.}

The thallus is in part epiphloodal, thin, evenly spreading to indistinctly areolate. The algæ are Protococcus instead of Chroolepus. The apothecia are urn-shaped, less hypophlœodal than in Pyrenula and larger. They break through the superimposed bark and have distinct apical pores from which the spores escape. Disk light color. Spores are long, filamentous, with numerous transverse septa; when once seen they will not be mistaken.

The genus requires further study; only one species has come to notice; it occurs upon trees, those of the smoother barks, as Betula and Acer. 
1. Conotrema urceolatum. Epiphlœodal portion of thallus evenly spreading, thin, whitish. Apothecia urn-shaped when fully matured, partially enclosed by thallus. Disk of a waxy color, margin black. Spores typical of genus, $140 \mu \times 5 \mu$.

\section{Thelotrema.}

As in Conotrema, the thallus is rudimentary and partly hypoplilœodal. The algæ are Chroolepus.

The apothecia are characteristic. They resemble a miniature volcanic crater. They are numerous and quite uniformly scattered over the thallus. Upon examining the opening at the top the whitish perithecium can be seen within; that is, the perithecium becomes separated from the more inflexible cone. A whitish, waxy coloration pervades the entire plant.

The spores are large, colorless, multilocular, spindleshaped, with a thick rugose spore-wall.

There is a considerable number of species which occur upon trees in the warmer latitudes.

1. Thelotrema lepadinum. Thallus thin, uniformly spreading, smooth, white to cream color. Apothecia usually numerous, conical, immersed, with a circular opening through which the light-colored perithecium can be seen. Spores large, colorless, spindle-shaped, 12 to 16 transverse septa, and a few longitudinal septa at the middle. Spore-wall thick, rugose, $51 \mu \times 13 \mu$.

\section{Gyrostomum.}

Thallus rudimentary. Apothecia quite small and semi-globose. Both thallus and apothecia begin their 
development below the surface of the substratum. The apothecia at maturity open by an apical pore which renders them uru-shaped. The perithecium is black. The spores are colorless, multilocular, with a thick gelatinous outer spore-wall which is not rugosely folded.

Only one species came to my notice, which is south. ern and grows upon various trees.

1. Gyrostomum scyphuliferum. Thallus "rudimentary, uniformly spreading, greenish-gray to brownish. Apothecia small, somewhat urn-shaped when mature. Disk dark to black. Spores typical of the genus, $35 \mu \times 13 \mu$.

\section{Vermearia.}

Thallus distinctly crustose and mostly epilithic or epiphloodal. It begins its development, however, below the surface of the substratum. In the rock-species the thallus begins its development upon the surface, but the lichen-acids disintegrate the rock, and the greater portion of the thallus (hyphr) becomes imbedded in the loosened particles. The alga are evidently Pleurococcus, though some authors report Chroolepus as the generic alga.

The apothecia are small, globose, more or less immersed in the thallus and substratum, perithecium dark or black. The paraphyses and spore-sacs are much gelatinized; so much so that they are scarcely discernible. The spores are simple, elliptical, colorless, and thin-walled. They generally bear oil-globules.

The Verrucarias have a wide range, and occur upon 
rock, perhaps rarely upon trees. The majority of socalled tree Verrucarias belong to other genera.

1. Verrucaria rupestris. Thallus deficient, dark or dirty color. Apothecia small, partially immersed; perithecium black. Spores typical, $15 \mu \times 6.5 \mu$.

2. Verrucaria pyrenophora. Thallus rudimentary, uniformly spreading, gray. Apothecia small, raised above the thallus. Disk somewhat flattened, black. Spores not found.

3. Verrucaria nigrescens. Thallus granular to indistinctly areolate, dirty gray to nearly black. Apothecia numerous, medium size, black. Spores typical, $12 \mu \times 7.5 \mu$.

4. Verrucaria muralis. Thallus indistinctly areolate, light to pale brown. Apothecia numerous. Disk projecting somewhat above thallus, black. Spores typical, $13 \mu \times 8 \mu$.

This lichen frequently occurs on brick, mortar, limestone, etc.

5. Verrucaria fuscella. Thallus comparatively thick, distinctly areolate, dirty gray to nearly black. Apothecia small, immersed, black. Spores typical, $13.5 \mu \times 6.5 \mu$.

6. Verrucaria margacea. Thallus thick, areolate, surface smooth; clay color. Apothecia numerous, almost entirely immersed, black. Spores large, pale yellowish, otherwise typical, $30 \mu \times 13.5 \mu$.

\section{Pertusaria.}

Thallus crustose, but more highly developed than in Verrucaria, though it varies considerably in thick- 
ness. Its color varies from gray to greenish-gray. The algæ are Protococcus. Soralia are quite common and seem to attain a high development in this genus. Darbishire, who has made a special study of the soralia of the Pertusarias, is inclined to the view that they are phylogenetically derived from apothecial structures.

The apothecia are globose and immersed in warty elevatious of the thallus. Usually there is no perceptible pore-opening. Absence of any marked coloration of the apothecia is characteristic. Spores are simple, large, colorless, one or two in each spore-sac. The inner spore-wall is reticulately marked in some species; oil-globules are often present.

Most of species are cosmopolitan; they occur upon bark and rock, less commonly upon moss.

1. Pertusaria pustulata. Thallus very deficient, grayish. Apothecia entirely immersed in the substratum, producing pustular elevations and finally opening by a minute apical pore. Spores typical, but inner wall not reticulate, $75 \mu \times 43 \mu$.

2. Pertusaria leioploca. Thallus deficient of scattered apothecial warts, greenish-gray to yellowishbrown. Apothecia wholly immersed in the warts. Spores typical (nor reticulate), usually four to six in each spore-sac, $60 \mu \times 22 \mu$.

3. Pertusaria multipuncta. Thallus usually entire, somewhat fissured, sometimes rugose or areolate, pale ash-gray. Apothecia immersed in thalline warts, single or confluent. Spores typical, inner spore-wall reticulate, $150 \mu \times 60 \mu$.

4. Pertusaria globularis. Thallus thin, apothecial 
warts united in groups of from two to six ; gray. Apothecia entirely immersed, small pore often visible. Spores typical but not reticulate, $95 \mu \times 33 \mu$.

5. Pertusaria glomerulata. Thallus consists of numerous confluent apothecial warts, nearly white to gray. Apothecia immersed, opening by small pores. Spores typical, inner wall reticulate, $150 \mu \times 60 \mu$.

6. Pertusaria communis. Thallus thick, rugose and somewhat fissured, gray. Apothecia in groups, immersed in apothecial warts, apical pore present. Spores typical, inner wall reticulate, $150 \mu \times 47 \mu$.

This species, as well as other species of the genus, were formerly included among the Pseudolichenes or Lichenes imperfecti, under the name of Variolaria. $P$. com. contains a large percentage of 'oxalate of lime and had been used in France as the source of oxalic acid. It was used as a remedy in fevers and as an astringent in intestinal troubles. Many Pertusarias were more or less recommended in the dyeing industries.

1. Pertusaria velata. Thallus thick, areolate, lightgray. Apothecial warts bearing apothecia which open by apical pores showing the pale disk. Spores very large, typical, but not reticulate, $180 \mu \times 65 \mu$.

\section{Dermatocarpon.}

The only representative of this genus which came to notice is generally included in the genus Endocarpon.

The thallus is very minute for a foliose type. Careful search with a pocket lens is necessary to detect it. It consists of a single entire lobe closely adnate to the substratum (rock) and is of a dark color. Several of 


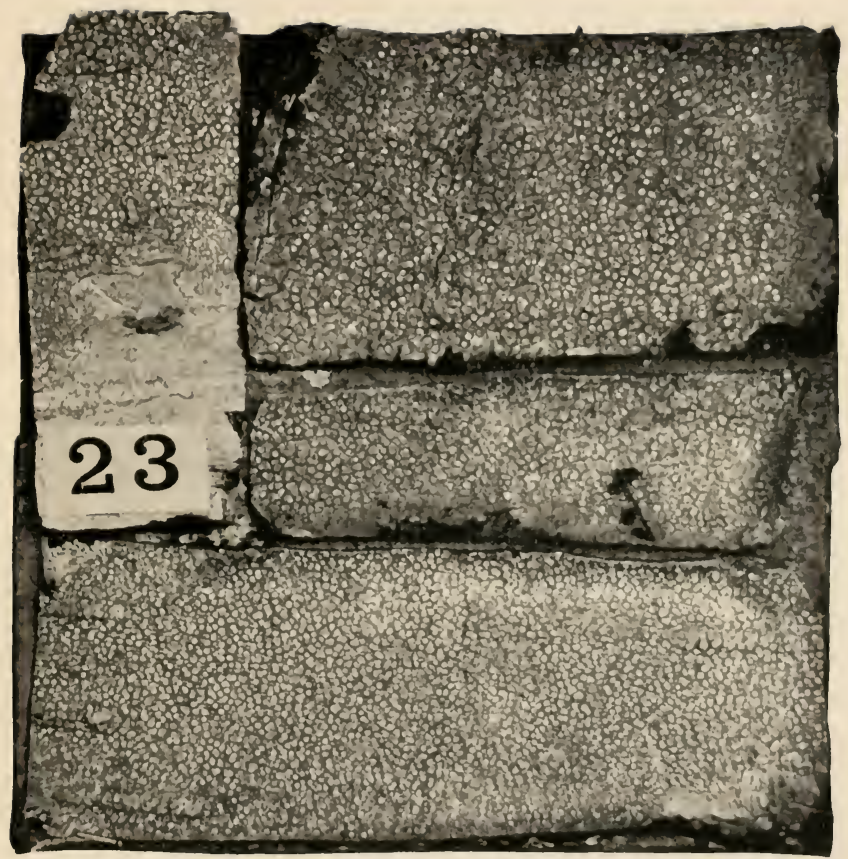

PIATE Ir. Crustose Types. From the collecotion of $\mathrm{X}$.

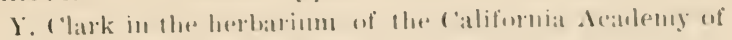
siciences. I'ertustriut volutu. 

these minute lobes usually occur in close proximity. The algre are Pleurococcus as in T'errucaria.

The apothecia are very small, usually one is immersed in each thallus-lobe. Quite generally minute single-celled algre (Pleurococcus?) occur above the thecium; these are known as thecial alga, and are ejected with the spores and enter into a symbiotic relationship with the germinating spore. The spores are colorless, multilocular, thus differing from those of Verrucaria and Endocarpon.

The only species occurs upon limestone, and seems to be southern in its range.

1. Dermatocarpon pusillum. Thallus-lobes entire, minute, widely scattered, closely adnate to the substratum, dark. Apothecia typical of the genus. Spores typical, two or three in each spore-sac, $23.5 \mu \times 18.5 \mu$.

\section{Endocarpon.}

In this genus the thallus is large, typically foliose, entire ; attached by a central portion (umbilicus) consisting either of a single lobe or numerous, nnore or less plicate, lobes. The thallus is quite thick and rigid and much less brittle than in Umbilicaria and Gyrophora. Color gray to dark-gray.

The apothecia are small, globose and entirely immersed in the thallus, opening by small dark pores, which are scattered over the thallus. 'The spores are simple, colorless, elliptical, the usual number (8) occurring in each spore-sac.

The Endocarpons occur principally upon rock, also upon soil and the bark of trees. 
1. Endocarpon hepaticum. Thallus of orbicular scattered entire lobes, variable in size, closely adnate to substratum (soil), margin turned upward, pale flesh color, changing to dark-brown; soralia sometimes present. Apothecia immersed. Spores typical, $13.5 \mu \times 5 \mu$.

The color of the thallus is very likely due to the presence of oxide of iron taken up from the soil.

2. Endocarpon arboreum. Thallus quite large, somewhat lobate, margin usually turned downward, attached by numerous long black rhizoids, upper surface gray to light-brown; lower surface dark. Apothecia immersed, scattered. Spores typical, $13 \mu$ $\times 5 \mu$.

3. Endocarpon fluviatile. Thallus quite large, lobate at margin, only loosely attached to substratum, upper surface gray to dark ; lower, gray to brown ; few rhizoids. Apothecia not seen.

4. Endocarpon miniatum. Thallus large, entire, attached by an umbilicus, upper surface smooth, gray to dark; lower surface pustulate, dark to black, with numerous fine rhizoids. Apothecia immersed and uniformly scattered, appearing as minute dark specks. Spores typical, $13.5 \mu \times 5 \mu$.

The pustules on the lower surface prove on examination to be apothecia, bearing spores. A so-called variety consists of numerous imbricate ascending lobes instead of a single thallus.

A coloring substance is extracted from this lichen, which is, however, said to be of an inferior quality. 


\section{COLLEMACEAE.}

This family is characterized by a foliose, dark-blue thallus, which is highly gelatinous when moist. As a rule, the thallus is thin and more or less lobate, attached by an umbilicus. The surfaces are frequently rugosely folded. Soralia are deficient. Rhizoids are also deficient excepting in the genus Mallotium. The alga are Nostoc, excepting perhaps in Hydrothyria. In all cases they are bluish-green, and occur in chains. This one character alone suffices to mark the representatives of the family. Owing to the supposition that the alga are not arranged in such well-defined layers as in the other foliose forms these lichens are spoken of as homoimerous. The algæ are, however, arranged in more or less definite layers, especially in the groups above Collema.

The apothecia are rather small, discoid and sessile upon the thallus. Spores vary in form and septation, and are mostly colorless.

\section{KEY TO THE GENERA.}

Cortical layers wantıng. . . . . 1. Collema. Cortical layers present.

Rhizoids deficient, thallus thin.

Lower surface of thallus not veined . 2. Leptogium.

Lower surface of thallus veined . . 3. Hydrothyria.

Rhizoids long, numerous, thallus comparatively thick . . . . . 4. Mallotium.

\section{Collema.}

This genus is represented by many species. The thallus varies from small and almost fruticose to quite large and typically foliose. The amateur will have 
no trouble in recognizing the more typical representatives. The dark-blue to almost black gelatinous (when moist) thin thallus is characteristic; these general characteristics, however, also apply to Leptogium. Upon a microscopical examination it is found that no cortical structure is present in Collema. The algæ (Nostoc) and hyphæ are loosely intermingled. The margin of the thallus is more or less divided or lobed.

The apothecia are small to medium in size, discoid, sessile upon the thallus. Disk concave, flattened or slightly convex, usually brown or reddish-brown.

The spore-characters are very variable. They may be simple, two to many-celled and multilocular. Upon further careful study it will no doubt be possible to subdivide the genus upon its spore-differences. Usually the spores are colorless; faintly colored spores, however, occur.

The Collemas occur upon soil, bark, rock, and are even found partially or wholly submerged in water. They seem to be somewhat western in their range; they are, however, also common south and east.

1. Collema pycnocarpum. Thallus medium, ascending lobes divided and narrowed; from yellowish-brown at the base to dark-blue green above. Apothecia very numerous, terminal and marginal margin not elevated. Disk convex, reddish-brown to dark-brown. Spores two-celled, colorless, elliptical, $13.5 \mu \times 6.5 \mu$.

2. Collema cyrtaspis. Thallus much as in C.pycnocarpum, larger and darker in color. Apothecia somewhat larger, crenate margin raised above the flattened 
dark-brown disk. Spores four to six-celled, colorless, spindle-shaped, $16 \mu \times 5 \mu$.

3. Collema myriococcum. Thallus medium, lobes ascending, more or less flexed and folded, surface somewhat granular or warty, dark-blue to black. Apothecia not seen, said to be small, numerous and somewhat immersed. Spores simple, colorless, $14 \mu \times 8 \mu$.

4. Collema leucopepla. Thallus thin, lying flat upon the substratum, rather indistinctly lobate, wrinkled above and below, often granular; dark-green above, somewhat paler beneath. Apothecia rather small. Disk reddish-brown, with a translucent whitish tinge. Spores acicular, four to six-septate, $51 \mu \times 3 \mu$.

5. Collema nigrescens. Thallus much as in C. leucopepla. Apothecia small, numerous. Disk flattened to convex, dark-brown. Spores acicular, resembling those of Bacidea, four to six-septate, $35 \mu \times 3 \mu$.

6. Collema ryssoleum. Thallus large, thin, lobes ascending; wrinkled and rugosely folded above, reticulate below; dark-green above, somewhat paler beneath. Apothecia small, much as in C. nigrescens. Spores colorless, spindle-shaped, $21 \mu \times 6.5 \mu$.

7. Collema pulposum. Thallus medium, comparatively thick, lobes imbricate and somewhat ascending, smooth, margin crenulate; leek-green to dark. Apothecia large, numerous, margin crenate and warty, extending above the concave brown disk. Spores colorless, spindle-shaped to ovoid, elliptical, four to sixcelled, rarely multilocular, $21 \mu \times 7.5 \mu$.

8. Collema laciniatum. Thallus rather small, lobes 
long, margin bearing short small branchlets; dark above, lighter beneath. Apothecia numerous, on short thalloid branches, margin somewhat crenulate, dark. Disk dark. Spores colorless, two-celled, small, $15 \mu \times 4.5 \mu$.

9. Collema plicatile. Thallus comparatively small, lobes narrowed, ascending, margin somewhat crenulate; nearly black above, somewhat less dark beneath. Apothecia small, on short thalloid branches, margin somewhat raised. Disk nearly black. Spores multilocular, oblong, irregular outline, constricted at the septa, $24 \mu \times 6 \mu$.

10. Collema crispum. Thallus medium size, comparatively thick, margin thickened and indistinctly crenulate; dark above, less dark beneath. Apothecia numerous, marginal, cup-shaped, margin crenulate and warty. Disk dark-brown. Spores multilocular, colorless, somewhat constricted at septa, $27 \mu \times 12 \mu$.

11. Collema flaccidum. Thallus large, lobes large, only slightly ascending, more or less folded and warty ; dark-blue, lighter beneath. Apothecia small, upon surface of thalius, margin entire and raised above the reddish-brown disk. Spores colorless, four to sixcelled, $23 \mu \times 6 \mu$.

\section{Leptogium.}

The thallus resembles the thallus of Collema. It is somewhat larger, thicker, and more rigid. The essential difference is made apparent upon a microscopical examination. In Leptogium there is a cortical structure consisting of a single row of cells. This cortical tissue is more highly developed in the apothecium, 
where it attains considerable thickness, otherwise the apothecia are as in Collema. The spores have the general characters of the spores in Collema.

There can be little doubt that this genus is simply a somewhat higher evolution than Collema. The two genera correspond in habitat and range.

Although a considerable number of species are known, we shall content ourselves with the deseription of a single species.

1. Leptogium chloromelum. Thallus medium to large, much wrinkled and folded, margin of lobes turned upward, bearing numerous isidioil outgrowths, dark-green. Apothecia medium, margin somewhat elevated, slightly rugose. Disk dark-brown. Spores colorless, multilocular, granular, $20 \mu \times 12 \mu$.

\section{Hydrothyria.}

Thallus quite large, flat, lobed, dark; distinctly veined below. The veins are simply bundles of hyphæ. The genus is represented by one species only. It is peculiar in that its habitat is on rock in clear running water, in which position it matures its spores. As a rule, lichens do not thrive in very moist places. Some doubt exists as to the nature of the symbiotic alga. Some authors maintain that they are Rivularia. They certainly are not normal Rivularia; it is likely that they are morlified Nostoc. Further study is necessary to determine this point.

1. Hydrothyria venosa. Thallus large, thin, lobes large, smooth, dull gray when dry; somewhat paler beneath and bearing branching veins. Apothecia few, 
medium, usually marginal, margin not raised. Disk convex, reddish-brown. Spores colorless, four-celled, oblong, elliptical, granular contents, $30 \mu \times 7 \mu$.

This rather rare and highly interesting lichen has been found in the New England States and in California.

\section{Mallotium.}

The thallus of this genus indicates a higher development than Leptogium; it is thicker and larger ; it frequently bears soralia or soredia; its cortical tissues are more highly developed. Color is dark-blue. The lower surface bears numerous very long delicate rhizoids. The algæ are Nostoc.

The apothecia are similar to those of Collema and Leptogium. As a rule, the few representatives which occur in the United States are found to be sterile.

They occur upon trees and rocks, and range from north to south, though they are quite rare. Generally Mallotium is classed with Leptogium. As a genus it requires further study.

1. Mallotium saturninum. Thallus large, quite thick, nearly monophyllous, margin lobate; upper surface granular, dull gray to dark-blue; lower surface bearing long, slender, grayish rhizoids. Apothecia not seen.

\section{PANNARIACEA.}

Considerable uncertainty exists as to the limitations of this family; genera are included which seem to have no possible genetic relationship to other genera (Ephebe, Lichina). The algal-characters vary greatly, and have been made the basis of the generic determination. The 
characters of the thallus also vary greatly; the smaller and more insignificant forms are fruticose; the higher forms are foliose. This seems to be contradictory to the arrangement of the Parmeliacer, in which family the fruticose forms are placed highest. Upon close examination it is, however, very evident that the fruticose forms of the Pannariacea are very lowly organized as lichens.

The algæ of this family are blue-green, with the exception of those of Psoroma and Sticta in which genera they are bright-green. As regards spore-characters, the only thing that can be stated here is that none are multilocular and that they are not very large; most of them are colorless. The apothecial-characters are as variable as the thallus-characters.

\section{KEY TO THE GENERA.}

Symbiotic algæ (Sirosiphon) forming the bulk of the thallus-structure of minute branching filaments . . Symbiotic algæ (not Sirosiphon) not forming the bulk of the thallus structure.

Thallus crustose, dark

Thallus fruticose, dark, minute.

Cortical tissue wanting, spores simple. Algæ in chains (Rivularia) . . . . Algæ singly (Gloocapsa) . · · · Cortical tissue present, spores twocelled, colorless

Thallus foliose.

1. Ephebe.

2. Lecothecium.

3. Lichina.

4. Omphalaria.

5. Polychidium.

Spores simple, colorless.

Apothecia innate in depression of thallus . . . . . . .

Apothecia discoid, sessile.

Algx singly, bright-green (Protococcus) coccus) . . . . . . . .

6. Heppia.

7. Psoroma.

8. Pannaria. 
Spores not simple.

Apothecia innate upon upper surface of thallus.

Spores acicular, 4-6 celled, colorless Spores two-celled, elliptical, brown 10. Solorina. Apothecia innate upon lower surface of upturned lobes ... . . 11. Nephromium. A pothecia discoid, sessile, spores acicular, 4-6 celled.

Algæ blue-green (Polycoccus) . . 12. Stictina. Algæ bright-green (Protococcus) : 13. Sticta.

\section{Ephebe.}

This genus evidently does not belong to this family since it has nothing in common with the other genera. The thallus is very minute, fruticose and dark in color. It consists of an alga (Sirosiphon pulvinatus) which is branching and through which the hyphæ of the fungal symbiont ramify. In that respect it is highly different from any other lichen-group; that is the alga forms the supporting and protecting structure while the fungus is the protected symbiont.

The Ephebes occur upon rock in moist places. It is in most instances very difficult to decide whether the plant be Ephebe or the alga Sirosiphon pulvinatus, which is exactly similar in form and in its habitat. Very frequently the plant bears spermagonia which at once proves it lichen-nature. I am even of the opinion that the spermagonia are the fungal symbionts; these appear as semi-translucent swellings along the side of the branches. A good pocketlens is necessary to make out the structure of the Ephebes.

1. Ephebe pubescens. Thallus minute, much branched, rigid when dry, more or less decumbent, 
dark to nearly black. Spermagonia sometimes numerous.

Considerable material from widely different localities has been examined, but no apothecia have been found. It is perhaps always sterile in this country. Lindsay and others report it as apothecia-bearing in Europe. Bornet, the noted French lichenologist, states that it is dicciaus, that is, the male reproductive organs (spermagonia) occur upon one plant, while the female organs (apothecia) occur upon another plant. It seems to be an undecided question whether Ephebe pubescens is a genuine lichen; it is perhaps only an alga (S. pulvinatus) parasitically associated with fungi (spermagonia and apothecia).

Tuckerman reports two more species, E. mammillosum and E. solida, both of which are said to resemble the one described.

\section{Lecothecium.}

Thallus crustose to perhaps minutely foliose, dark, closely adnate to substratum. The alga are bluishgreen and occur in chains (Rivularia nitida).

The apothecia are of medium size, discoid, sessile or partially immersed. The hypothecium is usually dark. sometimes blue-black. The spores are few, variable in size and form, due to the fact that but few attain maturity. When mature they are oblong, colorless, four-celled.

Only a few representatives are known in this country, they occur in the arctic regions and the north temperate zone. They grow upon rock or sandy soil. 
1. Lecothecium nigrum. Thallus crustose, granular, indistinctly areolate, nearly black. Apothecia small, somewhat raised above the thallus. Disk black. Spores oblong, colorless, indistinctly once to thrice septate, bearing oil-droplets, $13 \mu \times 5 \mu$.

This lichen is also known as Collema nigrum. It forms inky-black stains upon the rock on which it grows.

2. Lecothecium corallinoides. Thallus crustose to minutely scaly, scales ascending, dark-brown. Apothecia sessile, somewhat inmersed. Disk flattened, dark-brown. Spores few, elliptical, $14 \mu \times 5 \mu$.

This species is generally described as Pannaria microphyllum.

\section{Lichina.}

Thallus crustose, minute, branching, dark, somewhat resembling that of Ephebe, but differs in that the fungal symbiont forms the greater bulk of the structure and the protective tissue. The algæ are Rivularia nitida, hence blue-green and in chains. No cortical tissue is present.

The apothecia are small, terminal, globose, appearing as small nodular enlargements of the ends of some branches. They are dark. Spores are simple, elliptical, colorless. The hypothecium is colorless.

Only a few species are known, they occur upon rock in moist places and are found in the tropics as well as in the far north.

1. Lichina confinis. Thallus minute, branching, lobes rigid and erect, dark. Apothecia terminal, globose, dark. Spores colorless, simple, elliptical. 


\section{Omphalaria.}

Thallus small, fruticose, lobes flattened, dark. The apothecia are terminal, nearly globose, dark. In fact the genus closely resembles Lichina. The algal symbiont varies, however. Upon close examination it will be found that the predominating alga is single celled, with a thick, colorless, gelatinous covering, and is evidently Gloeocapsa polydermatica. Nostoc is, however, also present, at least in most specimens.

The spores are simple, colorless, elliptical; again they are evidently septate. They occur upon rock in the temperate and arctic zones. The genus requires further study.

1. Omphalaria umbella. Thallus small, attached by an umbilicus, branching, lobes flattened and crenulate, dark to nearly black. Apothecia terminal, globose to discoid. Disk brown. Spores simple, colorless, elliptical, $18 \mu \times 7.5 \mu$.

\section{Polychidium.}

Thallus small, fruticose, branching, lobes cylindrical, dark. There is a cortical tissue present, thus distinguishing the genus from the genera already described. The algæ are evidently Rivularia or modified Nostoc. The general gross characters of the thallus resemble those of Ephebe.

The apothecia are small, discoid, and sessile upon the basal portion of the thallus. Disk brown and hypothecium colorless. The spores are oblong, elliptical or spindle-shaped to somewhat curved, two-celled, colorless. This genus also requires further careful 
study; at present it is generally included under Leptogium.

1. Polychidium muscicolum. Thallus small, fruticose, much branched, lobes cylindrical, dark to oliveblack. Apothecia medium, discoid upon the older basal branches. Disk flattened to concave, brown. Spores typical of the genus, $25 \mu \times 8 \mu$.

This lichen is found growing over moss, on rocks, and occurs at great altitudes. It frequently occurs on high rocks facing the ocean.

\section{Heppia.}

Thallus of medium size, foliose; monophyllous, closely adnate to the substratum; margin more or less lobed; brown color, becoming quite dark with age. Rhizoids numerous. The alga are perhaps a species of Scytonema.

The apothecia are comparatively large, innate in concave depressions of the thallus, a characteristic not occurring in any other lichen-genus. The hypothecium is colorless. Disk reddish-brown. Spores are colorless, simple, thin-walled with granular contents, and variable in size and form.

1. Heppia Despreuxii. 'Thallus foliose, monophyllous, margin lobate, closely adlierent to substratum, dark. Apothecia typical of the genus. Spores typical, $22 \mu \times 9 \mu$.

There is perhaps only one authentic species in existence. The European specimens labelled $H$. urceolata and $H$. adglutinata are in all respects similar. $H$. Despreuxii is southern and occurs upon sandy soil. 


\section{Psoroma.}

Thallus foliose, branching, lying flat over substratum. The alga are Protococcus. It is perhaps probable that this genus is phylogenetically derived from Pannaria which genus it resembles in all but the algal characters.

Apothecia discoid, margin irregular. Disk reddishbrown. Spores colorless, simple, spindle-shaped.

1. Psoroma hypnorum. Thallus consisting of ascending scales which are more or less lobed, reddishbrown. Apothecia medium to large, margin crenulate and bearing thalloid outgrowths. Disk reddish-brown. Spores typical, $13.5 \mu \times 9 \mu$.

2. Psoroma stellata. Thallus of imbricate, many cleft, ascending lobes with crenate margin, pale brown above; whitish beneath with numerous rhizoids. Apothecia few, small to medium, sessile. Disk convex, pale brown to reddish-browu. Spores rare, not seen.

\section{Pannaria.}

Thallus foliose, lobed and usually of a reddish-brown color above, pale beneath. The lower forms, however, approach the crustose type. The alga are blue-green in color, and occur in groups (Polycoccus punctiformis). The apothecia are usually quite small, discoid, sessile. Disk flattened, with margin somewhat raised, reddishbrown; hypothecium colorless. The spores resemble those of the preceding genus.

The genus is somewhat southern in its range; the species occur upon moss, soil, rock and trees. At present 
considerable confusion exists as to the limitations of the genus.

1. Pannaria brunnea. Thallus from coarsely warty to minutely foliose, tawny-brown. Apothecia medium, margin rugose, warty. Disk flattened to concave, reddish-brown. Spores simple, colorless, granular, ends pointed, $18 \mu \times 9 \mu$.

2. Pannaria lepidiota. Thallus of small closely adnate or sometimes ascending lobes, branching, warty and more or less crenate, brown to dark-brown. Apothecia small, margin crenate. Disk flattened, reddishbrown to dark-brown. Spores simple or apparently twocelled, contents granular, oblong elliptical, $15 \mu \times 6 \mu$.

3. Pannaria leucosticta. Thallus foliose, adnate, lobed, much divided and more or less ascending, margin whitish; greenish-gray above, dirty gray beneath. Apothecia small, margin crenulate. Disk convex, reddish-brown. Spores simple, colorless, enclosed by a spindle-shaped gelatinous mass, $12 \mu \times 6 \mu$.

4. Pannaria luridum. Thallus quite large, lobed, brown to bluish-brown above; light-gray to bluish-gray beneath, with numerous dark rhizoids. Apothecia small, margin almost entire. Disk convex, pale chestnut to dark. Spores simple, colorless, spheroidal to spindle-shaped, spore-wall warty, $10.5 \mu \times 8 \mu$.

This lichen is often classed as Physma luridum.

5. Pannaria rubiginosa. Thallus much branched, margin faintly white; brown above, dark beneath. Apothecia rather small, margin crenate. Disk convex, reddish-brown. Spores spheroidal, spore-wall comparatively thick, $13 \mu \times 10 \mu$. 
6. Pannaria molybdaa. Thallus large, mostly entire, margin lobed, gray to bluish-gray; light-gray to yellowish beneath with gray rhizoids. Apothecia variable in size. Disk convex, irregular in outline, pale chestnut changing to nearly black. Spores simple or indistinctly two-celled, colorless, spindle-shaped, $11 \mu \times 4.5 \mu$.

\section{Peltigera.}

Thallus large, lobes rounded and large. As a rule the thallus is quite thick and rigid but not brittle. Color above is generally bright blue-green, which promptly changes to brown on drying; the lower surface is light-brown and bears large simple and branching rhizoids.

Upon examining a vertical section of the thallus it is found that no lower cortical tissue is present, as one would expect in so large a plant. The algæ are bluegreen, as in Pannaria (Polycoccus punctiformis).

The apothecia are quite large and are innate upon the upper margin or terminal upon special lobes. In outline the apothecia are orbicular to somewhat oval. The spores are acicular, colorless, three to five-septate, usually somewhat curved.

The range of the species is northern, though some occur south. They grow upon rock, more commonly upon soil in forest lands among mosses, also at the basal portions of tree-trunks. They do not thrive in open, exposed places.

1. Peltigera apthosa. Thallus large, lobes broad, upper surface sprinkled with flattened brown warts, 
bluish-green above; pale and reticulate beneath, with comparatively few large rhizoids. Apothecia medium, marginal on large lobes. Disk reddish-brown. Spores typical, $65 \mu \times 6 \mu$.

Some of the uses of this lichen have already been referred to elsewhere. According to Willemet, it was an excellent vermifuge when given in doses of twelve grains, evening and morning, during six or eight days. It was also said to possess emetic properties.

2. Peltigera canina. Thallus large, lobes large, rounded, greenish-gray and smooth above; beneath paler and reticulate with whitish rhizoids. Apothecia medium to large, marginal. Disk reddish-brown. Spores acicular, three to five-septate, $65 \mu \times 4 \mu$.

This is the lichen which obtained such renown as a remedy for the cure of hydrophobia. It was also considered to have diuretic properties.

3. Peltigera polydactyla. Thallus large, smooth above, greenish to brown; beneath reticulate with comparatively few rhizoids. Apothecia medium, terminal on narrowed thallus-lobes. Spores typical.

\section{Solorina.}

The thallus is quite large, foliose, rigid, and resembles the thallus of the foregoing in that the lower cortical layer is wanting. It is loosely attached to the substratum by long rhizoids. The upper surface is smooth and brown in color; the lower surface is light-brown to brick-red ( $S$. crocea). Two forms of algæe are present; one bright-green (Dactylococcus), the other blue-green (Polycoccus). 
The apothecia resemble those of Peltigera; the disk is brown to dark-brown. The spores are elliptical, two-celled and brown in color.

The Solorinas are northern in their range, occurring among moss, upon rock and soil.

1. Solorina crocea. Thallus rather small, not distinctly branching, closely adnate to substratum ; brown above, orange-red beneath, with darker veins. Apothecia medium to large. Disk reddish-brown. Spores typical of genus, $50 \mu \times 20 \mu$.

2. Solorina saccata. Thallus thinner than in $S$. crocea, paler. Apothecia medium, in depressions of the thallus. Spores typical, $50 \mu \times 20 \mu$.

\section{Nephromium.}

The thallus of Nephromium has a distinct, welldeveloped lower cortical layer, from the lower surface of which extend long rhizoids. In other respects the thallus resembles that of the Peltigeras. (The algæ are blue-green and occur in colonies as in Peltigera.)

The apothecia are more or less oval or kidney-shaped and are marginal upon the lower surface of upturned lobes, a character not found in any other lichen-group. The disk is reddish-brown. The spores vary from nearly acicular to oval, usually four-celled and brown.

Some species have bright-green algæ (Protococcus), and should be classed with another genus (Nephroma).

The species are northern in their range, and occur upon rock and tree-trunks in shaded places.

1. Nephromiumslavigatum. Thallus medium, lobes rather small, rounded, undulate, brown above; paler 
beneath and somewhat reticulate. Apothecia medium. Disk reddish-brown. Spores fusiform-elliptical, brown, $20 \mu \times 6 \mu$.

2. Nephromium Lusitanicum. Thallus medium, lobes deeply cut, sinnate, margin crenate, dark-brown; the interior appears yellowish. Apothecia and spores muth as in $N$. lavigatum.

3. Nephromium Helveticum. Thallus medium, lobes rather narrowed, undulate, smooth above gray to tawny; dark beneath. Apothecia medium. Disk dark. Spores as in $N$. lavigatum.

4. Nephromium tomentosum. Thallus large, lobes rounded, undulate and crenate margin, gray to reddishbrown above; paler beneath. Apothecia medium. Disk reddish-brown. Spores much as in $N$. lavigatum.

\section{Stictina.}

Most authors combine Stictina with Sticta, but owing to distinct algal differences we have kept them separate.

The thallus is large, lobed, medium in thickness and brittleness. It reminds one somewhat of Parmelia and Physcia. The lobes usually lie flat upon the substratum and are rather loosely attached by rhizoids. Color is generally dark-brown tinged with bluish-green. The algæ are blue-green and occur in colonies (as in Pannaria and Peltigera).

There is a morphological character by means of which one may recognize most of the representatives of Stictina as well as Sticta, and that is the occurrence of cyphellæ upon the lower suriace. (See 
Cyphella.) There are, however, exceptions (Sticta amplissima, S. pulmonaria, and several others).

The apothecia are rather small, discoid, sessile. Disk slightly concave, flattened to slightly convex. Spores colorless, oblong to acicular, four-celled.

The species are southern in their range, they occur upon trees and rocks.

1. Stictina tomentosa. Thallus medium, deeply lobed, pitted above and bluish-brown, paler beneath, with white cyphellæ and rhizoids. Apothecia medium, scattered, sometimes marginal. Disk reddish-brown to dark. Spores typical, $45 \mu \times 10 \mu$.

2. Stictina quercizans. Thallus rather large, lobes rounded and somewhat imbricate, sinnate and crenate, dark-brown above; rhizoids and white cyphellæ beneath. Apothecia rare, medium. Disk dark-brown. Spores typical.

There are a considerable number of species, but none have marked distinctive characters. The amateur will perhaps be satisfied to give the plants collected their generic position. In fact, by doing so he will do no small part toward defining the limitations of the two genera. Further study may show that the Stictinas and Stictas devoid of cyphella do not belong here.

\section{Sticta.}

Thallus in all respects similar to that of Stictina. Color less dark and less tinged with blue, owing to the fact that the algre are bright-green (Protococcus).

The apothecial and spore-characters are similar. 
Considerable variation has been noted in the apothecial characters of some Stictas which leads to the conclusion that some of the apothecia may be the fructification of a fungal parasite closely related to Arthonia. Particularly has this been observed in $S$. pulmonaria. Further careful research is necessary to determine the parasites living upon lichens. Let us hope that some of the amateurs for whom this book is written may make observations and studies which will aid in clearing up some of these mysteries.

The Stictas are less distinctively southern in their range. The change in algal symbiont may have enabled the plants to thrive in a colder climate. They occur upon rocks and trees.

1. Sticta amplissima. Thallus large, parmelioid, rather thin and papery, lobed, grayish-green and smooth above; brown beneath, with rhizoids but no cyphellæ. Apothecia rather large, numerous. Disk chestnut-brown. Spores colorless, long, slender, somewhat curved, indistinctly septate, $46 \mu \times 6 \mu$.

2. Sticta pulmonaria. Thallus large, lobes long, upper surface divided into concave areas, ridges and margin lined with soralia, dirty brown tinged with bluish-green; lower surface of convex areas lightbrown, no cyphellæ. Apothecia few, medium. Disk reddish-brown to dark. Spores very closely resemble those of Arthonia, $18 \mu \times 5.5 \mu$.

This lichen quite generally occurs at the base of trees (weather-side) at high altitudes. It is usually isolated, and the entire plant has the appearance of being decrepit and old, so that upon seeing it for the 

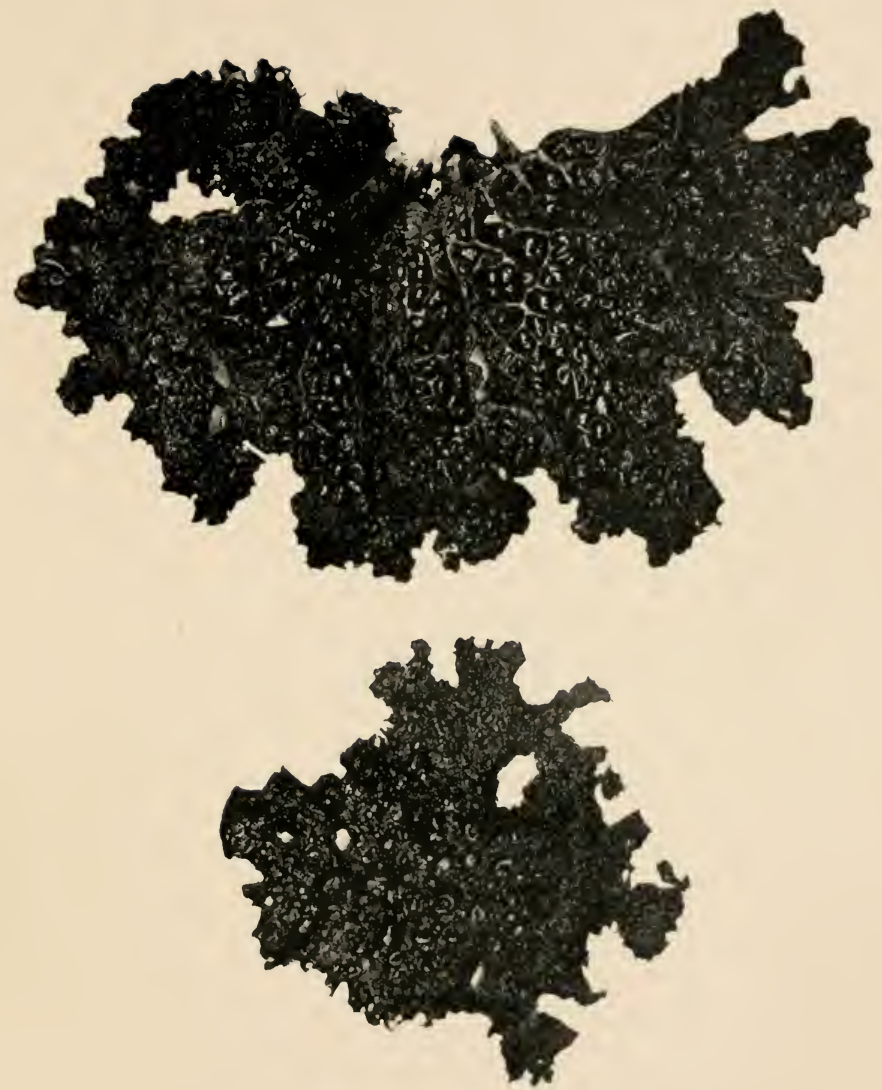

I'LATH: II. Foliose Types, thallus nearly entire. 1, stick pulmonerier, from Mt. Tamalpais, Matrin ('u., C'aliformia. 5, Imbilienria pustulate, from ('alifornia Academy of sicience. 

first time one is likely to pass it by hoping to find a "better" specimen.

"This lichen was at one time much prized as a remerlial agent and in the dyeing industry. Its specific name as well as its familiar designation 'lungs of oak' or 'tree lungwort' is due either to its efficacy, real or supposed, in pulmonary affections, as a nutrient, demullcent or tonic; or from a fancied resemblance between the reticulate character of the thallus and the mesh-like structure of lungs. The Swedish peasantry were wont to employ it in epidemic catarrh of cattle, especially of sheep; and in Germany, probably for similar purposes, it was given to cattle mixed with salt." - Lindsay. 



\section{LICHENES IMPERFECTI OR FALSE LICHENS.}

Formerly various lichens and parts of lichens were classed as Pseudolichens or Lichenes imperfecti. Of these six generic groups were recognized: Isidium Ach., Variolaria Ach., Lepra Hall., Pulveraria Ach., Spilonema Ach., Pyrenothea Fr. Isidium included the peculiar warty and isidioid outgrowths quite frequent on the upper surface of foliose thalli; it also comprised various sterile warty crustose lichens. Under Variolaria were included sterile forms of Pertusaria communis, $P$. lactea, besides other sterile crustose lichens of a gray or whitish color, especially those bearing numerous soredia. Lepra included the pseudolichen $L$. viridis as well as sterile forms of Placodium and perhaps Rinodina. Under Pulveraria were evidently included incipient primary thalli of Cladonia as well as sterile forms of Calicium, etc. The characters of Spilonema are very uncertain, referring, perhaps, to sterile forms of Graphis, Arthonia, etc. The term Pyrenothea referred, no doubt, to low forms of lichens (perhaps old, dying plants) bearing numerous spermagonia, pycnidia, or perhaps parasitic fungi. 
THE CONTINENTAL RANGE OF THE MORE IMPORTANT LICHEN GENERA OCCURRING

IN THE UNITED STATES.

The following table gives the general continental range of the lichen-genera represented in the United States. Some of the genera are not sufficiently known to indicate their true range; such are marked with an *. Those given under "U. S." are perhaps about uniformly distributed in the United States.

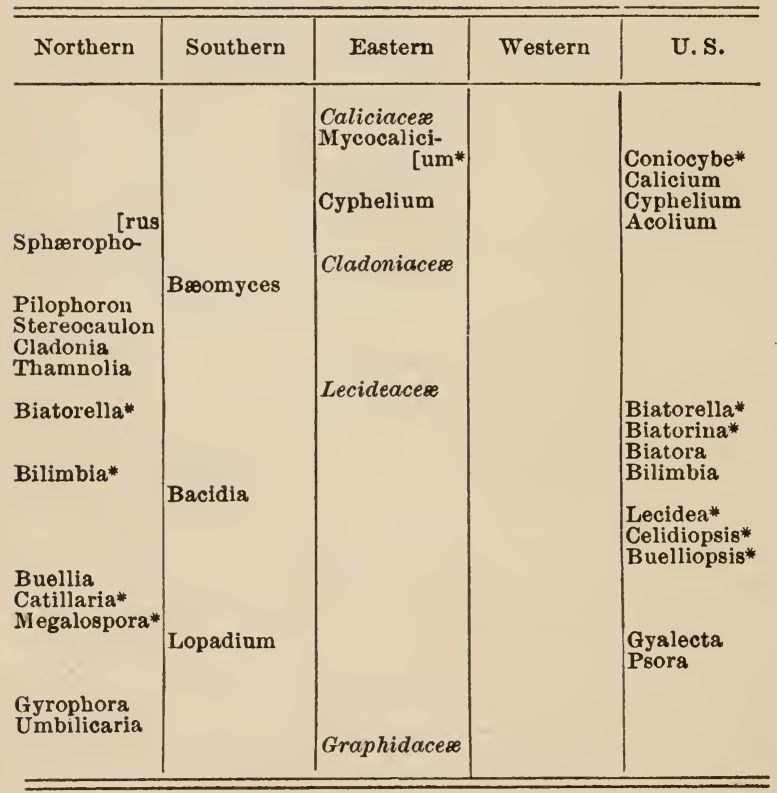


RANGE OF LICHENS IN THE LNITED STATES. 203

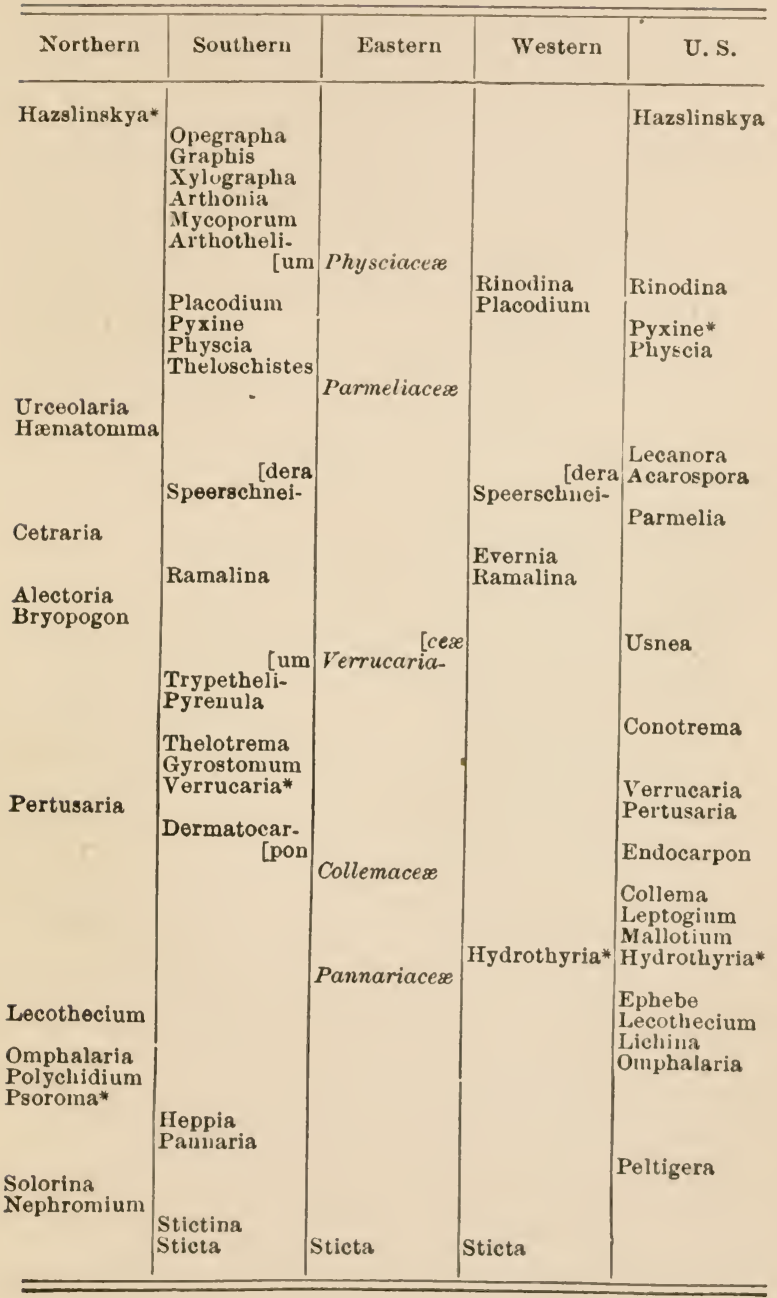



STATES.

THis list is by no means complete. It is, in fact, at present impossible to give the exact number of species occurring within the territory indicated. Willey believes that ultimately one thousand species will be found. No authentic list can be compiled until the existing species have been carefully determined. It is very probable that a considerable number of lichens have been described as distinct species which are in reality one and the same species; particularly is this true of the lower forms.

The list gives some idea of the number of species occurring in the various genera, and will be found of great value to those who wish to make exchanges or who wish to build up a fairly complete lichen-herbarium.

The families are given in their natural order, while the genera and species are given in alphabetical order. This arrangement in alphabetical order is simply for convenience of reference. The list gives about 1,250 species and varieties; of these, no doubt a considerable number are synonyms. Furthermore, there are a few doubtful genera and species which have been entirely omitted. It is highly probable that there are not more than 1,200 authentic species and varieties of lichens in the United States. 


\section{Caliciacee}

1. Acolium

Bolanderi
Californicum
Carolinianum
chloroconium
Hawaiiense
Javanicum
leucampyx
stigonela
Sti. Jacobi
tympanella
viridula

2. Acrocyphus sphærophoroides

s. Calicium

albo-nigrum
brunneolum
byssaceum
chrysocephalum
citrinum
Curtisii
curtum
disseminatum
eusporum
facultatum
fucipes
hyperellum
lenticulare
leucochlorum
leucopodum
melanophæum
microcephalum
parietinum
phæocephalum
polyporæum

præcedens pullatulum quercinum Ravenelii roscidum subcinereum subtile trachelium trichiale tubæforme turbinatum

4. Coniocybe. albella furfuracea pallida

5. Mycocalicium

Curtisii

fucipes

6. Pyrgillus

Americanus

\%. Sphcrophorus compressus coralloides fragilis

8. Sphinctrina anglica leucopoda turbinata

\section{Cladoniacea}

1. Baomyces
absolutus æruginosa byssoides fungoides placophyllus roseus 
2. Cladonia

alcicornis

amaurocræa

bellidiflora

Boryi

botrytis

cæspiticia

cariosa

carneola

cyanipes

cenotea

furcellata

ceratophylla

cornucopioides

cornuta

cristatella

ramosa

dactylota

decorticata

deformis

degenerans

delicata

digitata

Dilleniana

endiviafolia

fimbriata

tubæformis

radiata

Florkeana

furcata

a. crispata

b. ramosa

c. subulata

d. pungens

e. racemosa

gracilenta

gracilis a. verticilata

* cervicornis

** symphy carpia

b. hybrida

c. elongata

hypoxantha

leporina

macilenta

mitrula

papillaria

pulchella

pyxidata

b. pocillum rangiferina

b. sylvatica

c. alpestris

Ravenelii

santensis

symphycarpa

b. epiphylla

squamosa

turgida

b. conspicua

uncialis

3. Endogene

informis

4. Pilophoron

cereolus

a. fibula

b. Hallii

c. aucicularis

d. robustus

5. Siphula

ceratites

dactyliza

Pickeringii

Ramalinoides 


cornuta
simplex
subtabularis
6. Stereocuulon
albicans
alpestre
clavipes
condensatum
coralloides
denudatum
maderense
nanodes
paschale
piliatum
pilophoroides
proxinum
ramulosum
vimineum
Wrightii
tomentosum
b. Alpinum

7. Thamnolia

vermicularis

a. subuliformis

b. taurica

\section{Lecidiaceæ}

\section{Bacidia}
alborussula
atrogrisea
atrosanguinea
Beckhausii
chlorantlıa
chlorosticta
effusa
b. arcentina
fusco-rubella

incompta

inundata

medialis

microphyllina

millegrana

muscorum

rubella

rufescens

Schweinitzii

stigmatella

subabbrevians

suffusa

umbrian

\section{Bıatora}

ænea

anthrocoplila

apochrociza

atro-rufa

aurigera

carnulenta

cinnabarina

circumflexa

coarctata

b. Brugeriana

cuprea

denotata

Diapensix

ementiens

exigua

flavido-liviens

flexuosa

furfuracea

furfurosa

fuscescens

glebulosa

gramulusa

hypomela 
inspersabilis internectans Konyamensis leucophæa lucida mutabilis myriocarpoides Nylanderi oxyspora parvifolia

b. subgranulosa

c. corallina

peliaspis peliaspistes punctella pycnotheliza quernea rivulosa

b. mollis rubidula rufo-fusca rufo-fuscella russula sanguineo-atra spurococca subdeusta Torneonsis turgidula uliginosa varians vernalis viridescens

b. gelatinosa

3. Biatorella campestris cyphalea fossarum geophana

ilicis moriformis resinæ

4. Biatorina atro-purpurea cumulata cyrtella denigrata erysibe expallescens glauconigrans globulosa gyalizella Heerii lutea micrococca mixta pineti prasina

5. Bilimbia

allinita artyta caudata cupreo-rosella declinis Friesiana hyaliniza hypnophila leucoblephara melæna milliaria Nägelii obscurata pallidella parasitula sphæroides 


\section{suballinita \\ subfuscula \\ trachona \\ tricholoma \\ trisepta \\ verecunda}

6. Buellia

Africana

albo-atra

b. saxicola

allothallina

alpicola

amphidextra

atro-albescens

attendenda

badia

badio-atra

bolacina

Bolanderi

calcarea

Caloosensis

catasema

Catawbensis

colludens

coracina

decinerascens

destitula

dialyta

Elizæ

epigea

geographica

b. lecanorina

glaucomaria

glaucomarioides

halonia

ignobile

infernula inquilina

Japonica

lactea

lepidastra

leptocline

leucosepha

meiosperma

myriocarpa

b. polyspora

minimula

ochrodela

Oderi

oidalea

pappillata

parasena

parasitica

parasitula

parmeliarum

pertusaricola

petræa

b. grandis

c. Montagnæi

d. albinæ

præbadia

pulchella

pullata

Ravenelii

retrovertens

Rittokensis

saxatilis

scabrosa

Schæreri

Semitensis

semotula

Smithii

spuria

squamulata 
stellulata

stigmæa

trypethelia

turgescens

urceolata

vilis

\%. Buelliopsis

platycarpa

8. Cattillaria

grossum

9. Celidiopsis

vernicoma

10. Gyalecta

carneo-luteola

cupularis

faxicola

Flotovii

Friesii

geoica

* trivialis

lutea

nana

pineti

rhexoblephara

Valenqueliana

11. Gyrophora

anthracina

b. reticulata

Dillenii

erosa

flocculosa

hirsuta

hyperborea

Mühlenbergii

polyphylla proboscidea

b. arctica vellea

12. Lecidea

acclinis

aglart

aglæida

albocœrulescens

b. flavocœrulescens

alpestris

amylacea

arctica

b. pallida

Armeniaca

aromatica

assimilata

atrobrunnea

auriculata

diducens

Brandegeei

borealis

brachyspora

candida

caudata

cœruleonigricans

conferenda

confluens

contigua

b. hydrophila

crassipes

cruciarea

crytidia

cumulata

dendroclinis

dispecta

elata

enteroleuca

b. theioplaca

c. equata 
d. muscorum

e. achrista

f. flavida

g. ambigua

epiiodiza

erratica

flavovirescens

fusco-atra

fusco-cinerea

glaucospora

granosa

insularis

lapicida

Laurentiana

limosa

lugubrior

lugubris

lygotropa

mamillana

Manni

massata

melancheima

melapsepha

monticola

micy tho

neglecta

pallida

panocola

paraphana

parasitica

paupercula

planetica

platy carpa

poly carpa

Pringlei

pruniosa

psephota pyenocarpa

Rhætica

ruginosa

scrobiculata

Simodensis

sporostatia

speiorea

squalida

sublimosa

subtristisinscul\&

sylvicola

tenebrosa

tessellata

tessellina

ultima

variegata

vicellinaria

vorticosa

13. Lopadium

pezizoideum

vulpinum

14. Megalospora

porphyrites

sanguinaria

15. Psora

an thracophila

atro-rufa

caulophylla

crenata

decipiens

Friesii

globifera

b. rubiformis

icteria

luridella

ostreata

Petri 
rufo-nigra

Russellii

scotopholis

16. Sporastatia

morio

$b$. coracina

17. Toninia

aclinis

caudata

flavovirescens

granosa

massata

ruginosa

squalida

18. Umbilicaria

Pennsylvanica

pustulata

b. papulosa

IV. Graphidaceæ

\section{Arthonia}

abrothallina

albof uscescens

astericus

- astroidea

swartzoidea

atrata

carneo-rufa

caudata

chiodectella

cinnabarina

conturbata

cupressina

cyrtodes

diffusa

dispersa .

Eckfeldtii epipastoides

erubescens

erupta

excedens

exilis

fissurinea

Floridana

glaucescens

glebosa

gregaria

gregarina

hamamelidis

Hibernica

impallens

impolita

chiodectiodes

incarnata

lapidicola

lecideella

leucastræa

lurida

lurido-alba

mediella

melaspora

ochrolutea

opegraphina

oxytera

palmicola

paralia

platygraphidea

platyspeila

polymorpha

punctiformis

phyrrhula

phyrrhuliza

quintaria

radiata 
ramulosa

Ravenelii

reneformis

rubella

sanguinea

subastroidella

subcyrtodes

subminutissima

subminutula

subpalliduscula

subrubella

tædescens

tædiosa

terigena

varia

varians

velata

vernans

violascens

subcinerascens

Xylographica

2. Arthothelium

interveniens

macrotheca

mesoleuca

spectabile

3. Glyphis

Achariana

labyrinthica

4. Graphis
Afzelii
assimilis
Babingtonii
botryosa
columbina
cometia
dendritica

discurrens

Dumaslii

elegans

erumpens

eulectra

Floridana

glaucoderma

hæmatites

hololeucoides

hypoleptella

intricans

inusta

leiogrammodes

leprocarpa

leucocephcla

leucopepla

Mosquitensis

nitida

nitidella

nitidescens

oscitans

patellula

Pavoniana

Poitæoides

punctiformis

radiata

rigida

rufula

scalpturata

scolecites

scripta

limtata

recta

serpentina

varia

sophistica

striatula 


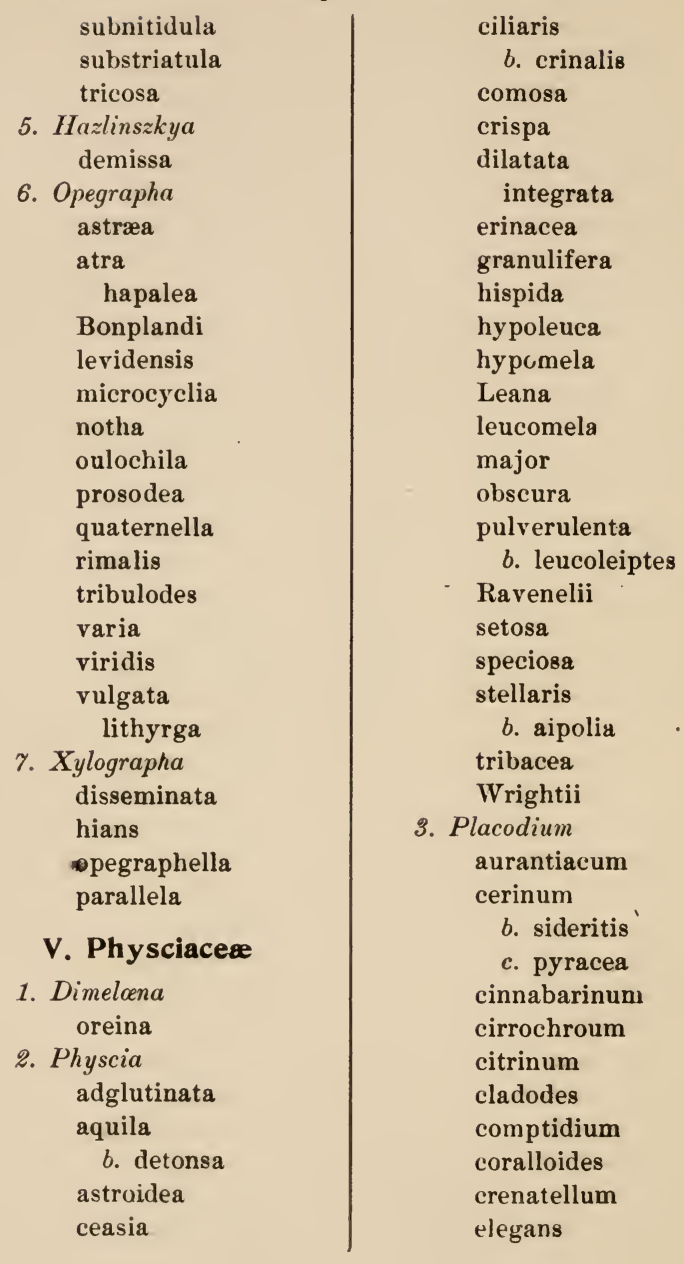


erythranthum

eugyrum

ferrugineum

b. Pallinii

c. discolor

d. Wrightii

ferruginosum

Floridanum

fulgens

b. bracteatum

galactophyllum

Jungermanniæ

luteominium

microphyllum

murorum

nivale

Paumotense

peliophyllum

phæum

rupestre

sinapispernum

spadiceum

Spraguei

variabile

b. atro-album

vitellinum

b. aurellum

4. Pyxine

cocoes

Frostii

Meissneri

picta

sorediata

5. Rinodina

ascociscana

aterrima

Bishoffi chrysomelana

Conradi

constans

flavonigella

Hallii

mamillana

milliaria

nimbosa

ochrotis

radiata

sophodes

b. atrocinera

c. tephraspis

d. confragosa

e. exigua

Thomæ

thysanota

turfaceæ

b. roscida

c. nuniaræa

6. Thelochistes

crysophthalmus

b. flavicans

concolor

b. effusa

flavicans

lychneus

parietinus

polycarpus

ramulosus

\section{Parmeliacere}

1. Alectoria

Fremontii

Japonica

a. bicolor

b. chalybeiformis 


\begin{tabular}{|c|c|}
\hline $\begin{array}{l}\text { c. implexa } \\
\text { Loxensis } \\
\text { nitulifera } \\
\text { ochroleuca } \\
\text { a. rigida } \\
\text { * asteina } \\
\text { ** nigrescens } \\
\text { b. cincinnata } \\
c . \text { sarmentosa } \\
\text { 2. Bryopogon } \\
\text { Oregana } \\
\text { jubata } \\
\text { 3etraria } \\
\text { aculeata } \\
\text { aleurites } \\
\text { b. placardia } \\
\text { arctica } \\
\text { aurescens } \\
\text { Californica } \\
\text { chrysantha } \\
\text { ciliaris } \\
\text { cucullata } \\
\text { Fahlunensis } \\
\text { Fendleri } \\
\text { glauca } \\
\text { b. stenophylla } \\
\text { Islandica } \\
\text { b. Delisæi } \\
\text { juniperina } \\
\text { b. terrestris } \\
\text { c. pinastri } \\
\text { lacunosa } \\
\text { b. stenophylla } \\
\text { marlreporiformis } \\
\text { nigricans } \\
\text { nivalis } \\
\text { Oakesiana }\end{array}$ & 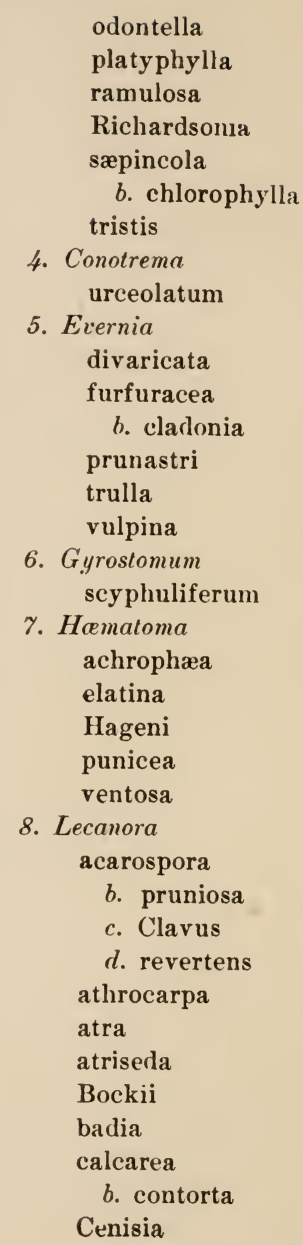 \\
\hline
\end{tabular}




\begin{tabular}{|c|c|}
\hline 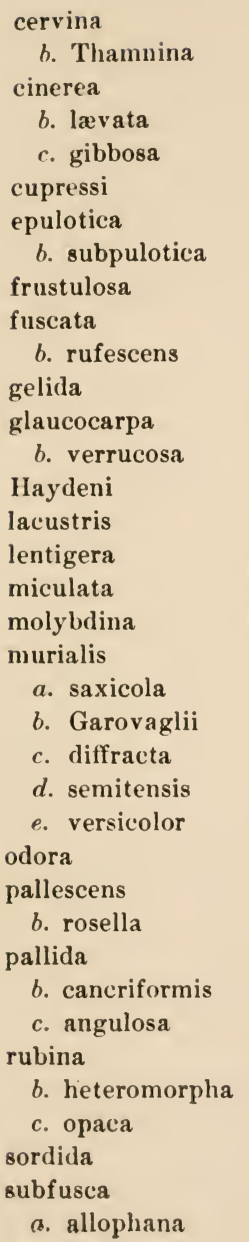 & 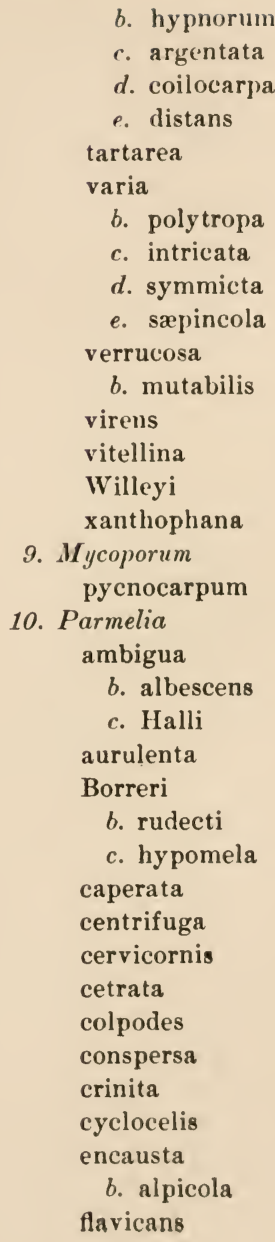 \\
\hline
\end{tabular}




glomulifera
hypoleuca
incurva
Japonica [icana
Kamtschadalis Amer-
lævigata
lanata
lattissima
leucochlora
lophyræa
molliuscula
olivacea
*aspidota
b. prolixa
* pannifornis
$c$. soridiata
perforata
*hyotropa
perlata
pertusa
physodes
$b$. obscurata
$c$. enteromorpha
$d$. vittata
placardia
revoluta
saxatilis
$b$. sulcata
$c$. panniformis
$d$. amphalodes
speciosa
subrugata
sulphurata
stygia
Texana
tiliacea
$b$. subleavigata

11. Pertusaria

c. relicina

d. sulphurosa

albinea

ambigens

bryontha

coccophora

colobina

communis

concreta

dactylina

euglypta

flavicunda

globularis

glomerata

lactea

lecanina

leioplaca

multipuncta

panyrga

pertusa

pustulata

rhodocarpa

velata

Wulfenii

12. Phlyctis

subtile

13. Ramalina

calicaris

a. fraxinea

b. fastigiata

c. canaliculata

$d$. farinacea

ceruchis

complanata

crinita

dasypoga 
denticulata

* canalicularis

homalea

leavigata

linearis

Manni

Menziesii

pollinarella

pollinaria

polymorpha

pusilla

b. geniculata

reticulata

rigida

Montagnæi

scopulorum

stenospora

usneoides

14. Speerschneidera euploca

15. Thelotrema

actinotum

Auberianum

auratum

catastictum

Cubanum

Domingense

glaucescens

granulosum

interpositum

lathræum

latilabrum

leiostomum

lepadium

lepadodes

leprocarpum leucastrum

lirelliforme

microcarpum

monosporum

myrioporum

piluliferum

platycarpoides

platycarpum

postpositum

Ravenelii

Santense

simplex

subtile

Wightii

Wrightii

16 Urceolaria

actinostoma

chloroleuca

cinerea

scruposa

17. Usnea

angulata

barbata

a. Florida

c. dasypoga

d. plicata

$e$. articulata

cavernosa

ceratina

hirta

longissima

mollis

rubiginea

strigosa

sulphurea

trichodea 
VII. Verrucariaces

1. Dermatocarpon pusillum

\%. Endocarpon arboreum cinereum

fluviatile hepaticum

Manitense miniatum complicatum fulv of uscum aquaticum

Moulinsii

Mühlenbergii ochroleucum pallidum pusillum rufescens tephroides Texanum

3. Pyrenula aggregata aspistea aurantiaca cinchonæ fallaciosa fetivica geminella gemmata glabrata hyalospora lactea leucochlora leucoplaca mamillana nitida oblongata ochraceo-flava pachy cheila punctiformis quinque-septata rhyponta subcinerea subprostans thelæna thelomorpha tropica

4. Trypethelium aggregata catervarium cruentum Eleuteriæ exocanthum Kunzei madrepiforme mastoideum megaspermum ochroleucum pallescens pyrenuloides scorites tropica uberinoides virens

5 V'errucaria centhocarpa consequella dermoplaca epigæa fuscella glabrata margacea maura 


microbola
mucosa
muralis
nigrescens
papillosa
pinguicola
prospersella
punctiformis
ruderella
rupestris
purpurascens
Sprucei
striatula
tartaricola
umbrina
virens
viridula

\section{Collemacese}

1. Collema

aggregatum
callebotris
cladodes
cocophorum
crispum
cristatellum
cristatum
cyrtaspis
flaccidum
furvum
glaucophthalnum
granosum
laciniatum
leptaleum
limosum
melænum
microphyllum

microptychium multipartitum myriococcum nigrescens

b. leucopepla plicatile pulposum pustulatum pycnocarpum ryssoleum stellatum stenophyllum tenax Texanum verruciforme

2. Hydrothyria venosa

3. Leptogium adpressum apalachense bolacinum bullatum Burgessii cæsiellum Californicum chloromelum

a. conchatum

b. stellaris corniculatum crenatellum dactylinum dendriscum hypotrachinum iuflexum intricatulum juniperinum lacerum 


marginellum
minutissium
palmatum
phyllocarpum
insidiosum
macrocarpum
pulchellum
rivale
sinuatum
tenuissimum
tremelloides

4. Mallotium albociliatum myochroum saturninum

\section{Pannariaces}

1. Ephebe mammillosum

- Lesquereuxii pubescens solida

2. Heppia arenivaga Despreuxii Guepii polyspora virescens

3. Lecothecium corallinoides nigrum

4. Lichina confinis

* Willeyi pygmea

5. Nephromium articum expallidum

Helveticum leavigatum

b. parile

Lusitanicum subleavigatum tomentosum

6. Omphalaria

Cubana

deusta

Gerardi

leptophylla

lingulata

phyllisca

pulvinata

pyrenoides

symphorea

Texana

Wrightii

7. Polychidium muscicolum

8. Pannaria

brunnea

byssina

carnosa

crassophylla

flabellosa

glaucella

grannatina

Hookeri

hypnorum

lanuginosa

lepidiota

leucosticta

lurida

melamphylla

microphylla 


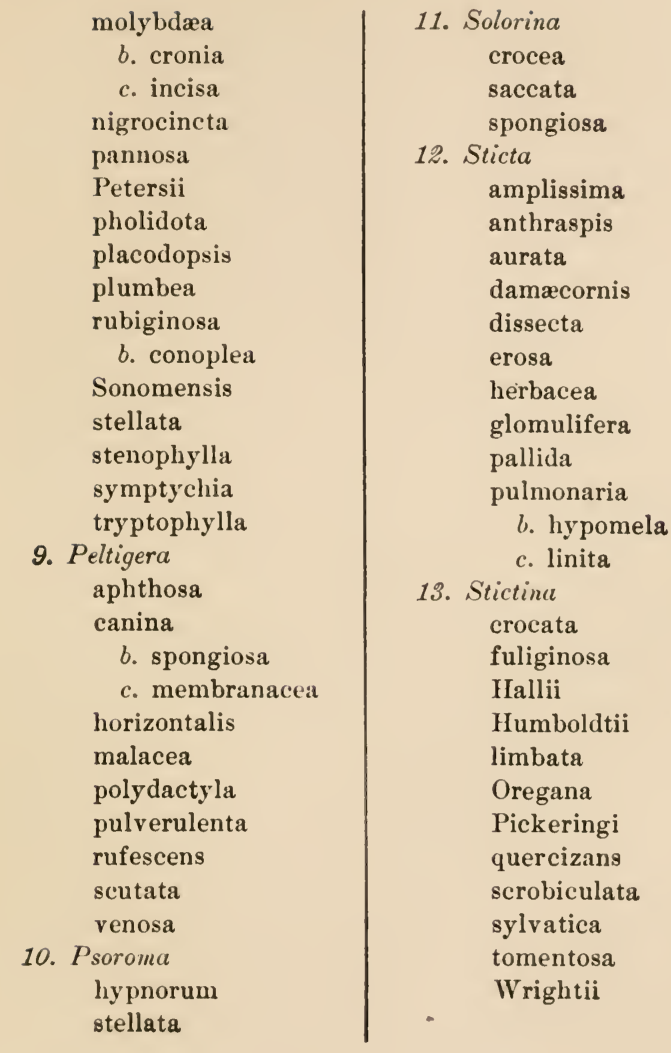





\section{GENERAL INDEX.}

Acarospora, 152

cervina, 152

dealbata, 153

privigua, 152

Accessory structures, 48

Acharius, 1, 6

Acids, 37

- action of, 18

Acolium, 85

tigillare, 85

Adaptations, mutual, 53

Aërial algæ, 33

Aftinity, double, 33

Affinity of licheris, 11

Africa, 3, 19

A gardh, 7

Agassiz, 149

Alaska, 20

Alcobol, 24

Alectoria, 165

ochroleuca, 165

sarmentosa, 165

A) gæ, 25

A]gal layer, 43

A]geria, 19

Alps, 149

Altruism, 31

Altruistic, 18

Analogy, 40

Audes, 111

Antberidia, 11

Aprothecia, 45

Arabia, 3
Arthonia, 128

astroidea, 129

atra, 131

dispersa, 129

glabrata, 130

lecideella, 130

polymorpha, 130

punctiformis, 130

quintaria, 130

radiata, 130

tædiosa, 130

varia, 131

Arthothelium, 132

spectabile, 132

Artiflcial key, 77

Asci, 28

Ascomycetes, 28

Assimilation, 26

Association, 31

Autonomy, 14

Bacidia, 109

albescens, 109

atrogrisea, 110

chlorosticta, 109

cuprea-rosella, 109

iuundata, 110

rubella, 110

Sch weinitzii, 110

suff usca, 110

Bacteria, 26, 27

Bæomyces, 87

æruginosus, 89 
Bæomyces. byssoides, 89 roseus, 88

Baranetzky, 13

Basidia, 28

Basidospores, 28

Beard-moss, 23, 168

Beer, 24, 168

Bertram, 168

Biatora, 105

cinnabarins, 107

contigua, 106

diapensiæ, 106

granulosa, 107

myriocarpoides, 106

parvifolia, 107

peliaspis, 107

russula, 107

uliginosa, 106

varians, 105

vernalis, 107

Biatorella, 104

geophana, 104

Biatorina, 104

lutea, 104

pineti, 105

Bilimbia, 108

hypnophila, 108

mixta, 108

sphæroides, 108

Bitter principle, 20

Blotting-paper, 66

Bornet, 13, 187

Brewing, 24

Brittleness, 57

Bryopogon, 166

jubata, 166

Oregana, 166

Bucke, 101

Buellia, 112

badia, 114

colludens, 114

coracina, 114

dialyta, 113

Elizæ, 114
Buellia.

myriocarpa, 114

Parmeliarum, 113

parasema, 113

pulchella, 115

Schæreri, 113

spuria, 115

stellulata, 114

Buelliopsis, 112

vernicoma, 112

Cæsalpinus, 4

Caliciaceæ, 81

Calicium, 83

Curtisii, 83

fuscipes, 83

hyperellum, 83

lenticulare, 83

quercinum, 84

Calkins, 144

Camerarius, 4

Canada, 20

Canary lslands, 21

Canary rock-moss, 157

Candelaria, 143

Cape Verde Islands, 21

Carbon dioxide, 32

Catillaria, 115

grossa, 115

Cave dwellings, 19

Celidiopsis, 112

platycarpa, 112

Centric, 4u

Cephalodia, 50

Cetraria, 157

ciliaris, 158

cucullata, 159

Fahlunensis, 158

Islandica, 19, 159

juniperina, 158

lacunosa, 159

Cheese, man ufacture of, 27

Clislblains, 161

Chlorophycese, 34

Chlorophyl1, 26, 27 
Chroolepus umbrina, 34

Cladonia, 92

alcleoruis, 96

amaurocraa, 100

bellidiflora, 97

cæspiticia, 94

cariosa, 95

cenotea, 96

cornucopioldes, 97

cristatella, 95

decorticata, 95

deformis, 97

clelicata, 94

digitata, 93

timbriata, 98

furcata, 99

gracilis, 98

lepidota, 96

leporina, 100

wacilenta, 95

mitrula, 94

papillaria, 93

pulchella, 94

pyxidata, 96

rangiferina, 19,100

squamosa, 99

symuphearpa, 94

turgłda, 99

uncialis, 99

verticillata, 98

Cladoniaceæ, 87

Classification, 73 methods of, 75

Cold, 36

Collecting-box, 58

Collection of lichens, 56

Collema, 179

crispum, 182

eyrtaspis, 180

Haccidum, 182

laciniatum, 181

leucopepla, 181

limosum, 8

myriococeum, 181

nigrescens, 181
Collema.

plicatile, 182

pulposum, 181

pycuocarpum, 180

ryssoleum, 181

Collemaceæ, 179

Color, restoration of , 63

Couiocybe, 82

furfuracea, 82

pallida, 82

Conotrema, 171

urceolatum, 172

Cousortism, 12

Cora, 28

Cortical layer, 42

Cortical tissue, 47

Crabbe, 100

Crab's-eye lichen, 150

Crombie, 12

Crottle, 150, 156

Crystals, acid, 43

Cudbear, 22

Cyanophyceæ, 35

Cyphelium, 84

tubæforme, 84

turbinatum, 84

Jyphellæ, 49, 196

Cystococcus humicola, 34

Dactylocoecus, 35

Darbishire, 14

Dark crottle, 150

De Bary, 12

De Candolle, A. P., 6

De Notaris, 2

Dermatacarpon, 176 pusillum, 177

Dillen, 5

Diœcious, 187

Dioscorides, 3, 21, 23

Disintegration of rock, 17

Disk, 126

Dog-lichen, 23

Dropsy, 168

Dryers, 66 
1)ye, 21

I)yeing, 20

Earth-bread, 19

Elephantissis, 20

Endlicher, 7

Endocarpon, 177 arboreum, 178

fluviatile, 178

hepaticum, 178

miniatum, 178

Evernia, 163

furfuracea, 3, 16t

vulpina, 22, 164

Evolution, 39

Ephebe, 186 mammillosum, 187 pubescens, 186 solida, 187

Epidermis, 40

Epilepsy, 23

Eschweiler, 7

Esenbeck, Nees von, 8

Excrescences, 56

Exine, 86

Exosporium, 86

Exodus, 19

Ezekiel, 21

Fabricius, 23

Fairies, 156

Fairy rings, 49, 154

False lichens, 200

Famintzin, 13

Faveoli, 17

Federigo, 21

Fée, 7

Feld-elfin, 156

Female organs, 11

Fermentation, 26

Fevers, 23

Food-substances, 26

inorganic, 26

organic, 27

France, 22, 150
Franklin, 20, 12I

Freezing, 36

Fries, 7, 10

Function, loss of, 27

mechanical, 31

of lichens, 17

Fungal type, 46

Fungi, 26

spores of, 37

Generation, spontaneous, 7, 9

Georgi, 6

Germany, 10

Gessner, 3

Glass, 23

Glœeocapsa, 35, 189

Glueing, 67

Gonidia, 9, 11

Graphidacex, 124

Graphis, 127

dentritica, 127

elegans, 127

eulectra, 127

scripta, 127

Green monld, 30

Green substance, 8

Gyalecta, 117

cupularis, 117

Gyrostomum, 172

scyphuliferm, 173

Gyrophora, 119

Dillenii, 122

erosa, 121

floculosa, 121

hyperborea, 1:0

Mühlenbergii, 121

proboscidea, 120

vellea, 121

Hæmatomma, 146

ochrophæa, 147

punicea, 147

ventosa, 147

Hair-powders, 23

Haustoria, 41 
Hazslinskya 125, demissa, 126 gibberulosa, 126

Hedwig, 6

Hemans, Mrs., 97

Heppia, 190 adglutinata, 190

Despreuxii, 190 ureeolata, 190

Herbarium, 65

Heterocysts, 35

Heterothecium, 116

Himalayas, 111

IIistory, 1

llorse-tall lichen, 166

Hué, 12, 52

Humboldt, 168

Hydrophobia, 23

Hydrothyria, 183

venosa, 183

Hypothallus, 133

Hysterium, 34

Icelaud, 20

Iceland moss, 19, 159

Iceland scurvy, 20

Idle moss, 168

Individualism, 31

Insects, 44

Iodine reaction, 19

Ireland, 155

Isidium, 200

Isle of Man, 155

Isolateral, 40

Israelites, 19

Italy, 3, 21

Itzigsohn, 11

Jaundice, 23, 159

Jumelle, 13

Key, artificial, 77 natural, 80

Keys, 76

Körber, 10
Krempellubler, 1

Labelling, 69

I amarek, 7

Leaf, 37,40

Lecanora, 148

atra, 150

Bockii, 149

calcaria, 149

cenisia, 151

- Cupressi, 149

esculenta, 19

Hageni, 149

lacustris, 148

muralis, 151

orosthea, 148

pallescens, 150

- pallida, 149

rubina, 151

subfusea, 150

tartarea, 151

varia, 149

Lecidea, 110

enteroleuca, 111

geographica, 111

melancheima, 111

panæola, 111

Lecldeace $\rightsquigarrow, 102$

Lecothecium, 187 corallinoides, 188 nigrum, 188

Ledges, 61

Leighton, 12

Lepra, 200

viridis, 200

Leptogium, 182

chloromelum, 183

Lichen-algæ, 37

Lichen-starch, 19, 37

Llchen-tundra, 52

Lichenes imperfecti, 200

Lichenin, 19, 37

Lichenology, history of, 1

Lichens, altitudinal range, 52 autonomy of, 14 
Lichens.

eleaning of, 66

collection of, 56

continental range of, 202

distribution of, 52

economic value of, 18

false, 200

function of, 17

latitudinal range of , 52

list of, 204

worphology of, 39

naming of, 63

occurrence of, 52

origin of , 25,29

physiology of , 39

preservation of, 65

relation to algæ, 33

relation to fungi, 33

sets of, 65

spores of, 37

study of, 63

uses of, 16

Lichina, 188 confinis, 188

Lindau, 14

Lindley, 7

Lindsay, 11

Limné, 5, 16, 124

Litmus, 22

Liverworts, 7

Lopadium, 116 pezizo:deum, 117

Lungs of oak, 199

Lungwort, 199

Male organs, 11

Mallotium, 184

saturninum, 184

Malphigi, 4

Manna, 19

Massalonga, 10

Mead, Dr., 23

Medullary layer, 43

Medullary tissue, 47

Megalospora, 116
Megalospora.

sanguinaria, 116

Metamorphosis, 9

Meyer, 2, 8

Micheli, 1, 4

Microcosmos, 36

Micrometer, 82

Micron, 82

Microscope, 9, $6 t$

Moisture, 62

Moustrosities, 16

Morison, 4

Morphology, 39

- Mosses, 4, 5

Mould, 26

Mounting sheets, 6 ?

Mucor, 83

Mudd, 10

Mummies, 3

Mycopor um, 131

pyenocarpum, 131

Nägeli, 11

Natural key, 80

Neoformations, 50

Nephromium, 195

Helveticum, 196

lævigatum, 195

Lusitanicum, 196

tomentosum, 196

Nostoc lichenoides, 35

Nostoc muscorum, 8

Note-book, 62

Nova Zembla, 111

Nux vpmica, 23

Nylander, 10, 52

Oken, 7

Omphalaria, 189

umbella, 189

Opegrapha, 126

varia, 126

vulgata, 126

Orchella-weed, 22

Orchill, 22 
Organs, female, 11 male, 11

Oricellarii, 21

Orseille, 22, 150

Pannaria, 191 brumea, 192 lepidota, 192 leucosticta, 192 luridum, 192 molybdæa, 193 rubiginosa, 192

Pannariaceæ, 184

Paper, manufacture of, 24

Paraphyses, 47

Parasitism, 12, 27

Parchment, 161

Parmelia, 153

Borreri, 156

conspersa, 154

caperata, 155

latissima, 157

multisporum, 154

olivacea, 155

perforata, 157

perlata, 157

physodes, 155

saxatilis, 156

tæniata, 155

Parmeliaceæ, 144

Parry, 101

Paste-board, 24

Patella, 29

Peltigera, 193

aphthosa, 50, 193

canina, 23, 194

polydactyla, 19 \&

Perfumes, 24, 101

Pertusaria, 174

commuuis, 176

globularis, 175

glomerulata, 176

leioploca, 175

multipuncta, 175

pustulata, 175
Pertusaria.

velata, 176

Phylogenesis, 32

Phylogeny, 36

Physcia, 138

adglutinata, 139

aquila, 140

cæsia, 139

ciliaris, 141

comosa, 141

hispida, 141

hypoleuca, 140

obscura, 139

parietina, 23

pulverulenta, 140

setosa, 139

speciosa, 141

stellaris, 140

tribacea, 140

Physciacex, 132

Physiology, 39

Pilophoron, 89

cereolus, 89

Placodium, 135

aurantiacum, 136

ceriu $11 \mathrm{~m}, 136$

cinnabarinum, 136

citrinum, 136

elegans, 137

ferrugineum, 136

murorum, 136

Pleurococcus vulgaris, 35

Plinius, 3, 21

Pockets, 68

Podetium, 46, 92

Poisoning, 22

Poly-ancestry, 32

Polyeoceus punetiformis, 35

Polyps, 6

Polychidium, 183

muscicolum, 190

Porcher, 121

Potatoes, 20

Powders, lıair, 101

Preservation of lichenf, 65 
Priestley, green substance of, 8 Primal substance, 8

Propagation, vegetative, 3

Propagative organs, 49

Protococcus vulgaris, 8

Prototype, 32

Pseudo-lichens, 200

Psora, 118

atro-rufa, 119

decipiens, 119

icteria, 118

rufonigra, 119

Rusellii, 119

Psoroma, 191

hypnorum, 191

stellata, 191

Puff-balls, 26

Pulveraria, 200

Pustules, 178

Pycnidía, 51

Pyrenoid bodies, 35

Pyrenothea, 200

Pyrenula, 170

aspistea, 171

nitida, 171

Pyxine, 137

cocoes, 138

picta, 138

sorediata, 138

Quinine, substitute for, 23

Kabies, 23

Ramalina, 160

calicaris, 160

ceruchis, 161

homalea, 161

iniuuscula, 160

polymorpha, 161

reticulata, 162

rigida, 162

Range, continental, 60 ,

Red cup moss, 97

Red pepper, 23

Reicheubach, $\boldsymbol{7}$
Reindeer moss, 20, 101

Reinke, 2, 12, 13

Rejuvenescence, 43

Rhizoids, 44

aërial, 44

Rinodina, 133

Bishoffii, 134

chrysomelæna, 135

constans, 134

oreina, 134

sophodes, $13 t$

turfacea, 135

Rivularia nitida, 35

Rocella, 3, 21, 162

leucophæa, 163

tinctoria, 163

Rock, disintegration of, 17

Rock-hair, 166

Rock -moss, 122

Rock-tripe, 20

Roman empire, 21

Roots, 44

Rucellai, 21

Rucellarii, 21

Ruellius, 3

Rust, 26

Sac-fungi, 28

Sanders, 24

Saprophytes, 28, 29

Saussure, 149

Schwendener, 2, 11

Serap-book, 68

Scrofula, 168

Scurvy, 20

Scytonema, 190

Shakespeare, 168

Sirosiphon, 35, 186

Snails, 43

Solomon, 3

Solorina, 194

crocea, 195

saccata, 195

Soralia, 14, 107

Soralium, 49 
Soredia, 6, 37, 48

Soredium, 49

Speerschneidera, 153 euploca, 153

Spermagonia, 6, 11, 50, 100

Spermatia, 10, 51

Spermatozoa, 11

Sphærophor us, 86

fragilis, 86

globiferus, 86

Spilonema, 200

Spore-characters, 10

Spore-sac, 28, 47

Spores, 28

Sprengel, 7

Stahl, 12

Stane-raw, 156

Staney-rag, 156

Starch, 19

Sten-laf, 156

Stereocaulon, 90

condensatum, 90

coralloides, 91

denudatun, 91

paschale, 91

ramulosum, 91

Sterigmata, 51

Sticta, 49, 197

amplissima, 198

Oregana, 50

pulmonaria, 198

Stictina, 49, 196 quercizans, 197

tomentosa, 197

Stitzenberger, 10

Stone-crottles, 155

Study of lichens, 63

Sturgis, 12

Substance, primal, 8

Substrata, 53

Sweden, 20

Switzerland, 10

Symbionts, 31

Symbiosis, 12

antagonistic, 31
Symbiosis.

mutualistic, 31

Systems, 73

artificial, 73

natural, 73

Tanning, 24, 27

Tartars, 13

Tartary, 19

Thalline type, 47

Thallophytes, 39

Thallus, 39

crustose, 40

foliose, 40

fruticose, 40

secondary, 92

vertical, 92

Thamnolia, 102

vermicularis, 102

Thecæ, 47

Thecium, 47

Thekes, 47

Theloschistes, 142

chrysophthalmus, 143

concolor, 142

flavicans, 143

leucomela, 144

lychneus, 142

parietinus, 143

polycarpus, 142

Thelotrema, 172

lepadinum, 172

Theophrastus, 1, 3, 4, 21

Toad-stools, 26, 88

Tournefort, 1

Tree-hair, 166

Tree-moss, 168

Tripe de roche, 121

Trypethelium, 170

virens, 170

Tuckerwan, 12

Tulasne, 11

'Type, crustose, 47

foliose, 52

fruticose, 44 
Type.

fungal, 46

thalline, 47

Ulf-mossa, 22, 164

Umbilicaria, 20, 123

papulosa, 123

Pennsylvanica, 124 pustulata, 124

Umbilicus, 44

Units, morphological, 66

Urceolaria, 145 actinostoma, 146 seruposa, 146

Usnea, 3, 167 barbata, 23, 168

linearis, 167

longissima, 168

Variolaria, 200

Vasculum, 58

Velvet-moss, 122

Verrucaria, 173

fuscella, 174

margacea, 174
Verrucaria.

muralis, 174

nigrescens, 174

pyrenophora, $17 t$

rupestris, 174

Verrucariaceæ, 169

Vesurius, 92

Virey, 22

Voigt, 7

Wallroth, 2, 8

Weather-side, 60

Weber, 1

Whooping-cough, 23, 168

willey,

Wolf's-moss, 22, 164

Woronin, 13

Xylographa, 128

opegraphilla, 128

parallella, 128

York, duke of, 23

Zømbla, 111 


\section{PLATES AND DESCRIPTIONS}

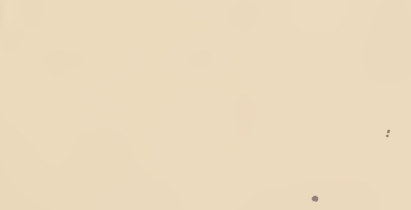




\section{PLATE I.}

Algal Types.

1. Cystococcus (Protococcus). The individual cells are surrounded by terminal branches of hyphæ known as haustoria.

2. Chroolepus. The branching chain of cells is enclosed by haustorial hyphæ.

3. Nostoc. The chains are intermingled with hyphæ, which form no haustoria. The larger cells in the chains are known as heterocysts.

4. Glococapsa. The cells are small, enclosed by a thick stratified gelatinous covering which is penetrated by the haustorial branches.

5. Rivularia. Algæ and hyphæ. In Nostoc as well as in Rivularia the individual chains are enclosed by a gelatinous substance.

6. Polycoccus. Cells form colonies which are enclosed by haustorial hyphæ.

7. Dactylococcus. The cells are elliptical.

8. Pleurococcus. The cells are irregular in outline and enclosed by a dense hyphal structure.

9. Sirosiphon. This is a branching many-celled alga. The figure represents a terminal branch. Hyphæ are not shown. 

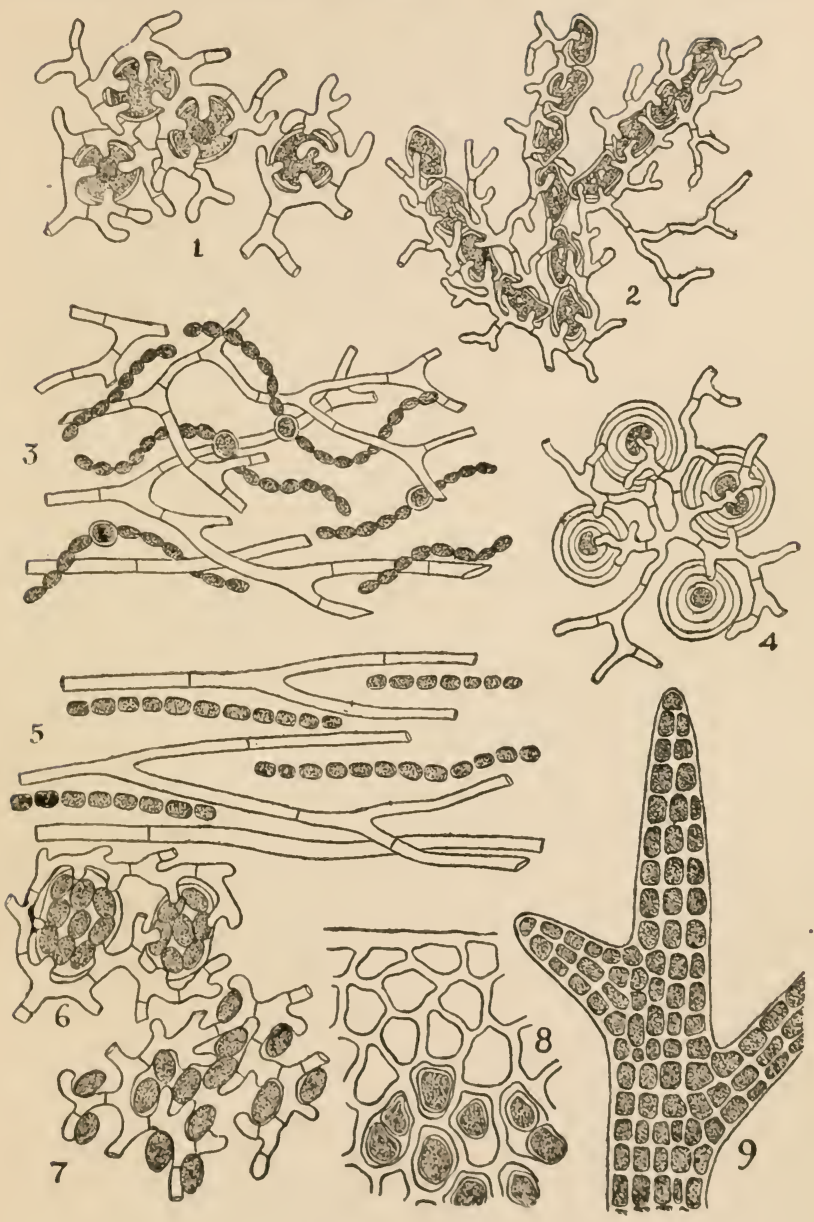

ALGAL TYPES. 


\section{PLATE II.}

\section{LICHEN-T Y PES.}

Crustose forms :

1. Culicium hyperellum.

2. Graphis scripta.

3. Rinodina oreina.

Foliose forms :

4. Endocarpon miniatum.

5. Collema nigrescens.

6. Sticta pulmonaria.

Fruticose forms.

7. Cetraria Islandica.

8. Rocella tinctoria.

9. Usnea barbata.

1,2 and 3 are about natural size. 4 to 9 inclusive are some what reduced. 6,7 and 9 represent only portions of plants. 


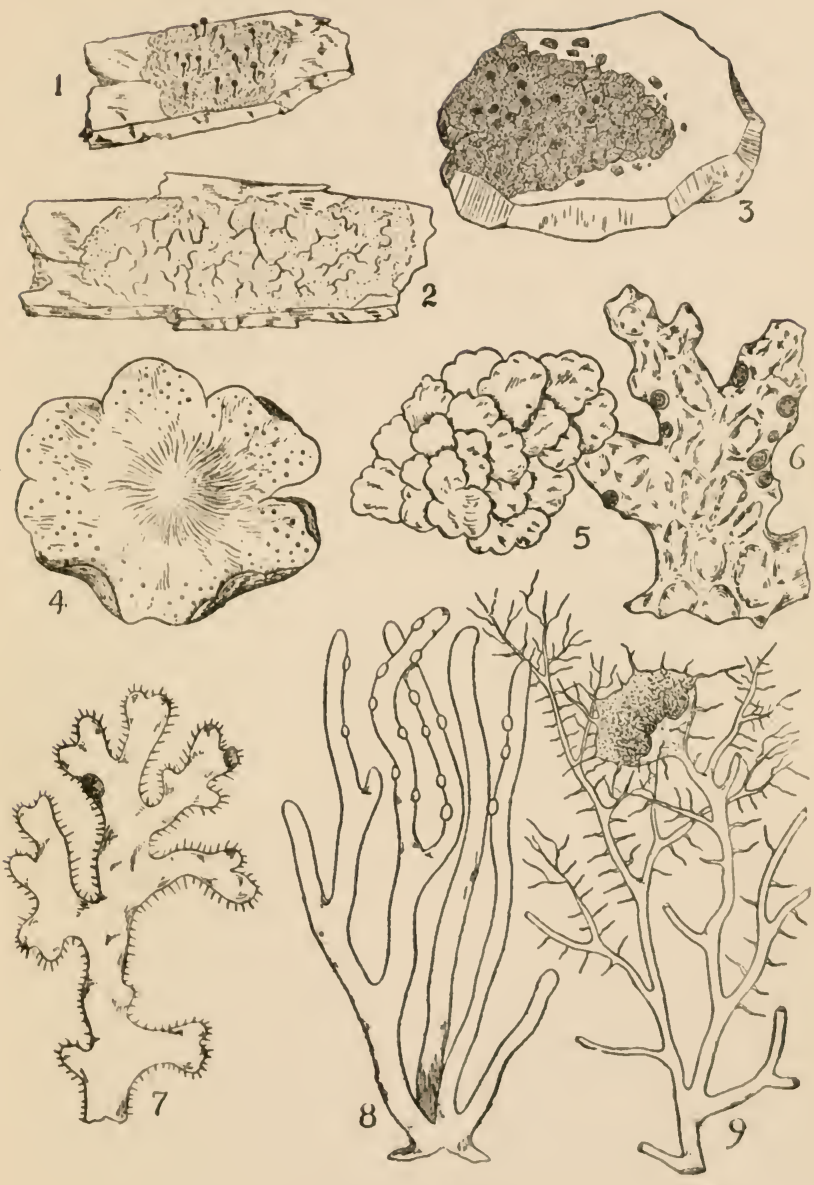

LICHEVTYPES. 
PLATE III.

Histology of a Foliose lichen.

(Stictu amplissima.)

1. Vertical section through apothecium:

$a, b$, thecium, consisting of the spore-sacs and paraphyses; $a$, colored ends of paraphyses ; $c, d$, hypothe cium ; $c$, upper hyphal layer; $d$, lower cortical layer; $e$, upper algal layer; $f$, medullary layer; $g$, lower algal layer; $h$, cortical layer; $i$, rhizoids (aërial).

2. Vertical section through thallus:

$a$, epidermal layer ; $b$, upper cortical layer ; $c$, algal layer;

$d$, medullary layer; $e$, lower cortical layer; $i$, rhizoids.

3. Paraphyses and spore-sac more highly magnified.

4. Spores highly magnified.

5. Algæ (Protococcus) and haustoria.

1 and 2 magnified about 300 diameters ; $:, 4$ and 5 more highly magnified. 
GUIDE TO LICHENS Schneider

Plate III.
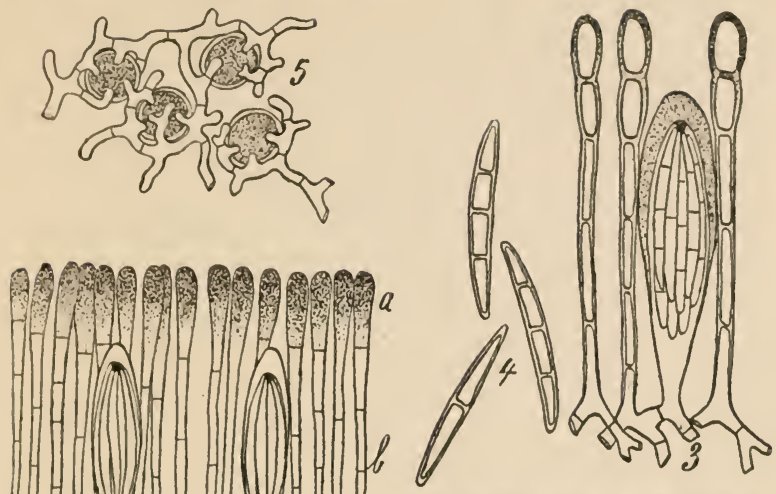

1205

3) 1 ans

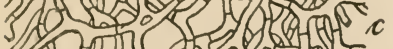

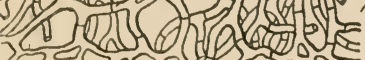
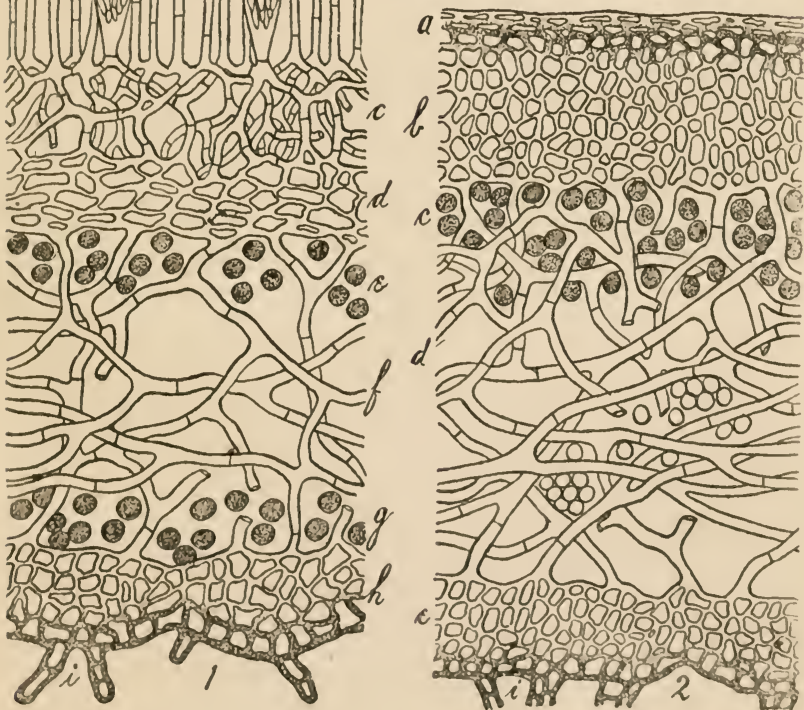

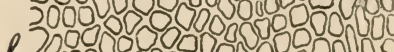
l. 300000000000000000

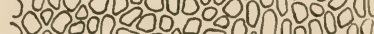
30000 S 50000000 $c$ (4)

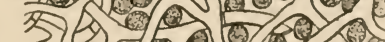
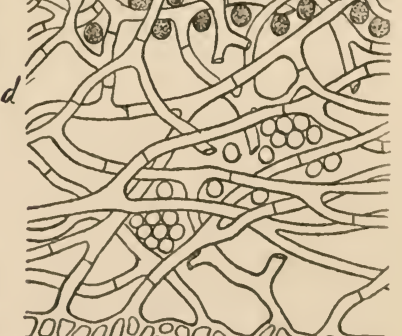
30000000000 5000 * 7000000000000000000

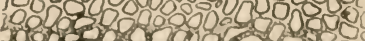

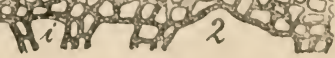

HISTOLOGY OF A FOLIOSE LICHEN.

(Sticta amplissima.) 


\section{PLATE IV.}

\section{Apothecial and Thalline Types.}

A pothecial types :

1. Fungal type of apotherium as it occurs in the Caliciaceæ.

2. Fungal type of apothecium as it occurs in the Cladoniaceæ and sone Lecideaceæ.

3. Fungal type of apothecium as it ocrurs in the majority of Lecideaceæ.

4. Thalline type of apothecium as it ocrurs in the Physciaceæ and Parmeliaceæ.

5. Immersed type of apothecium as it occurs in Endocarpon and other genera.

Thalline types:

6. Crustose thallus.

7. Crustose thallus with upper cortical layer.

8. Foliose thallus without upper cortical laver.

c). Foliose thallus with both cortical layers.

10. Fruticose thallus as in stereocaulon.

11. Fruticose thallus as in Cladonia.

12. Fruticose thallus as in Usnea.

All the figures are diagramatic; 1 to 9 inclusive represent vertical sections; 10,11 and 12 , longitudinal sections. 
GUHDE TO LICHINS. Schneider.

Plats IV.

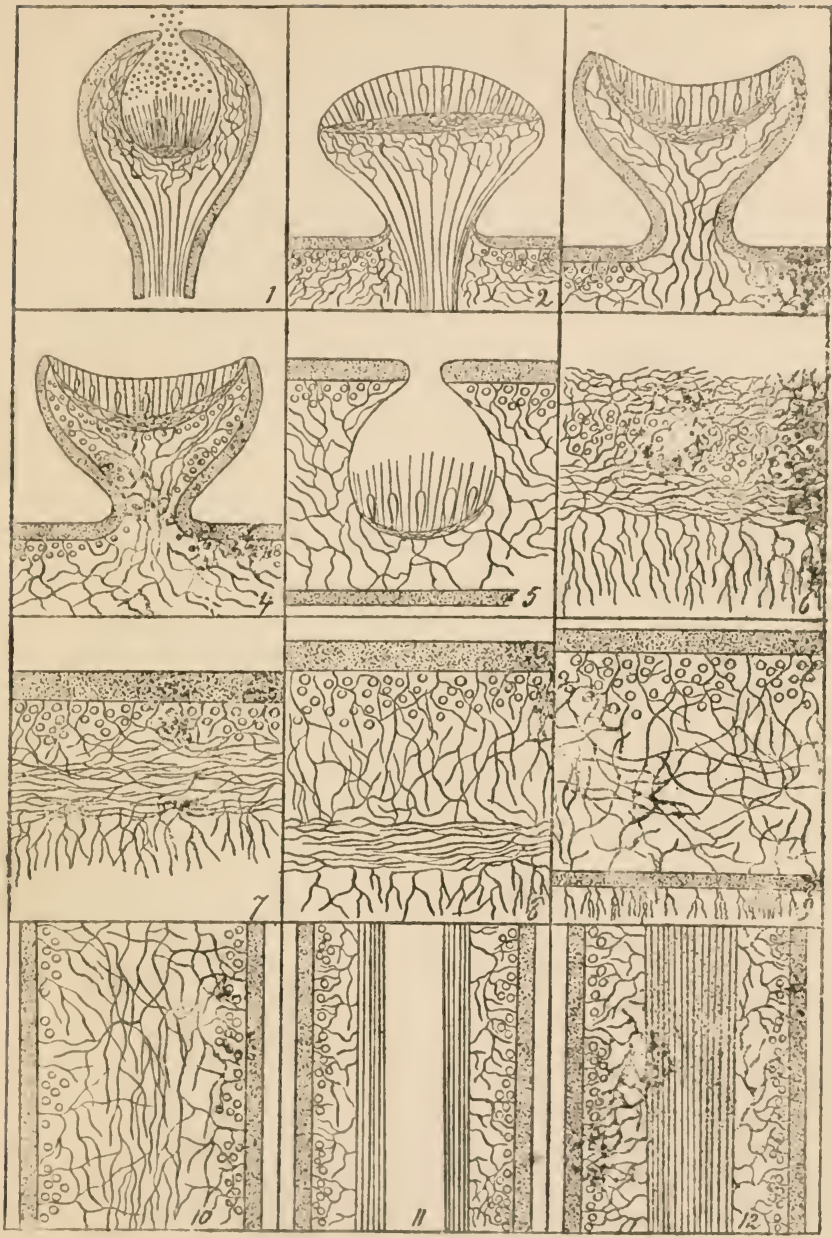

APUTHELIAL AVD IHALLIVE TIPES. 


\section{PLATE V.}

Generic Spore-tyfes.

1. Acarospora.

2. Acolium.

3. Alectoria.

4. Arthonia.

5. Arthothelium.

6. Bacidia.

7. Bæomyces.

8. Biatora.

9. Biatorella.

10. Biatorina.

11. Bilimbia.

12. Bryopogon. 
Plate. V.

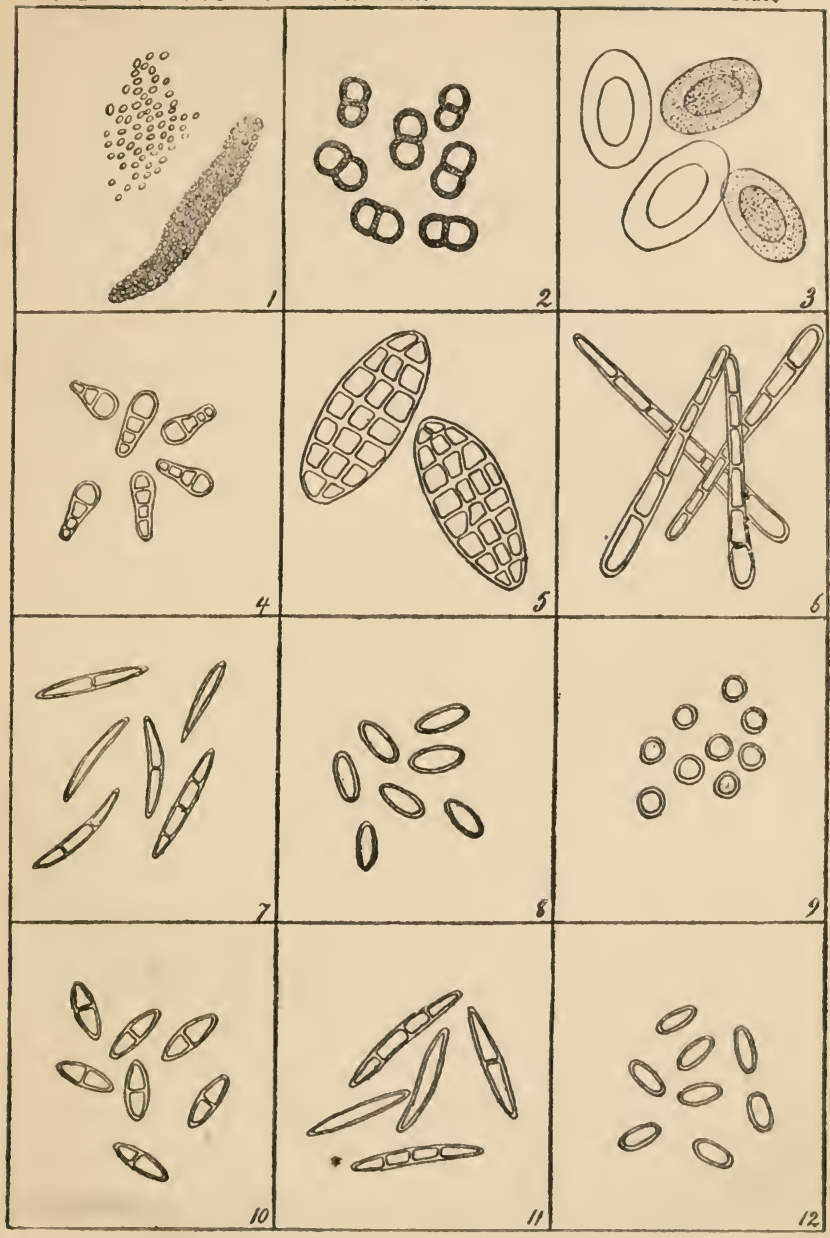

SPORES. 
PLATE VI.

Generic Sipore-types (CON.).

13. Buellia.

14. Buelliopsis.

15. Calicium.

16. Catillaria.

17. Celidiopsis.

18. Cetraria.

19. Cladonia.

20. Collema

21. Coniocybe.

22. Conotrema.

23. Cyphelium.

24. Dermatocarpon. 


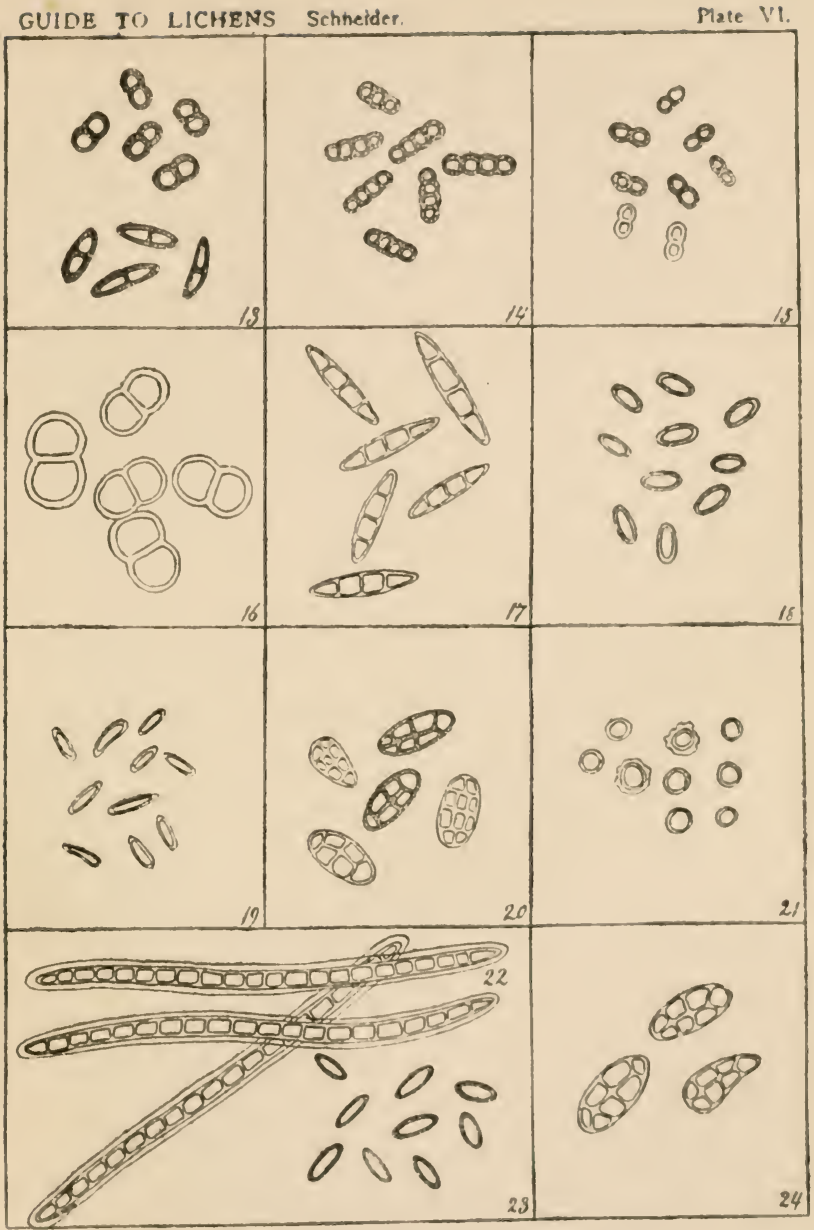

SPOKES. 


\section{PLATE VII.}

Gexeric Spore-types (CON.).

25. Endocarpon.

26. Ephebe.

27. Evernia.

28. Graphis.

29. Gyalecta.

30. Gyrophora.

31. Gyrostomun.

32. Hæmatomma.

33. Hazslinskya.

34. Heppia.

35. Hydrothyria.

36. Lecanora. 


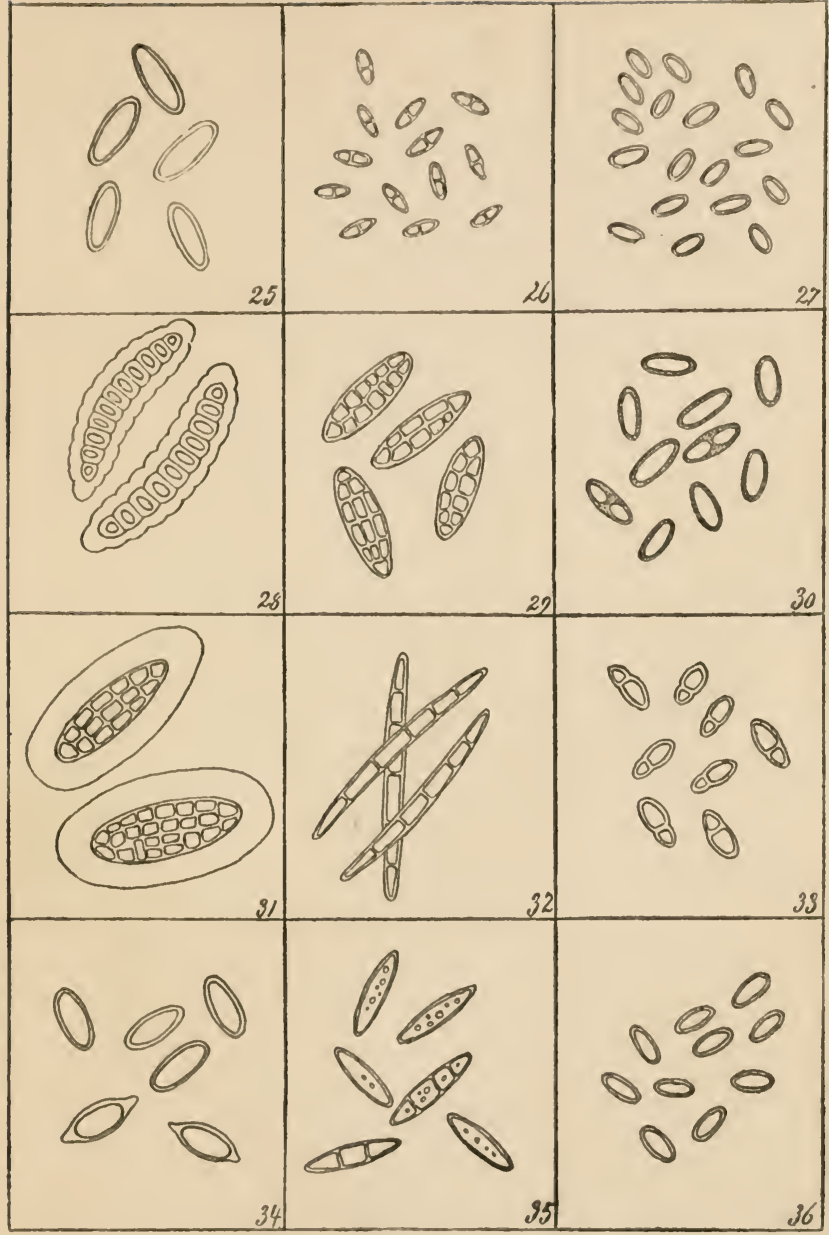

SPORES. 
PLATE VIII.

Generic Spore-types (con.).

37. Lecidea.

38. Lecothecium.

39. Leptogium.

40. Lichina.

41. Lopadium.

42. Mallotium.

43. Megalospora.

44. Mycoporum.

45. Nephromium.

46. Omphalaria.

47. Opegrapha.

48. Pannaria. 


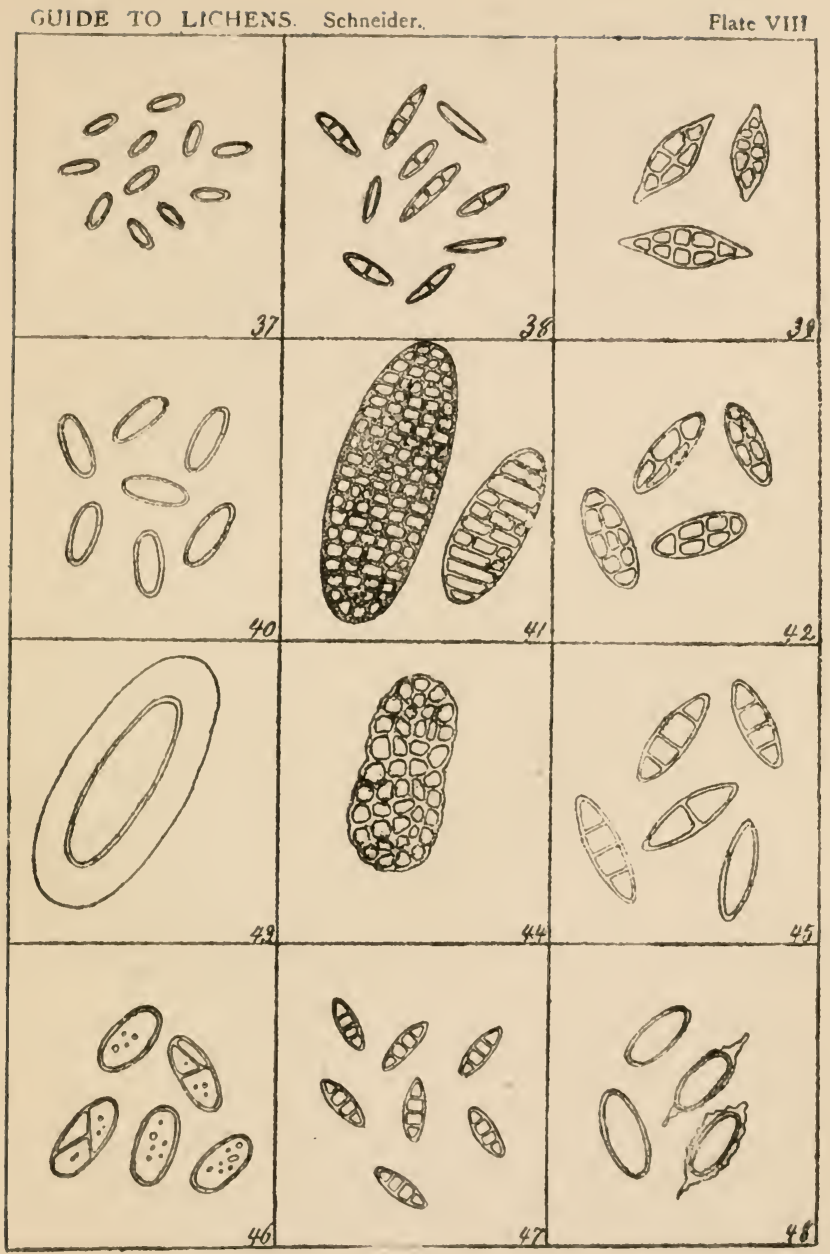

SPORES. 


\section{PLATE IX.}

\section{Generic Spore-types (Con.).}

49. Parmelia.

50. Peltigera.

51. Pertusaria.

52. Physcia.

53. Pilophoron.

54. Placodium.

55. Poly chidium.

56. Psora.

57. Psoroma.

58. Pyrenula.

59. Pyxine.

60. Ramalina. 
GUIDE TO LICHENS Schneider.

Plate DX

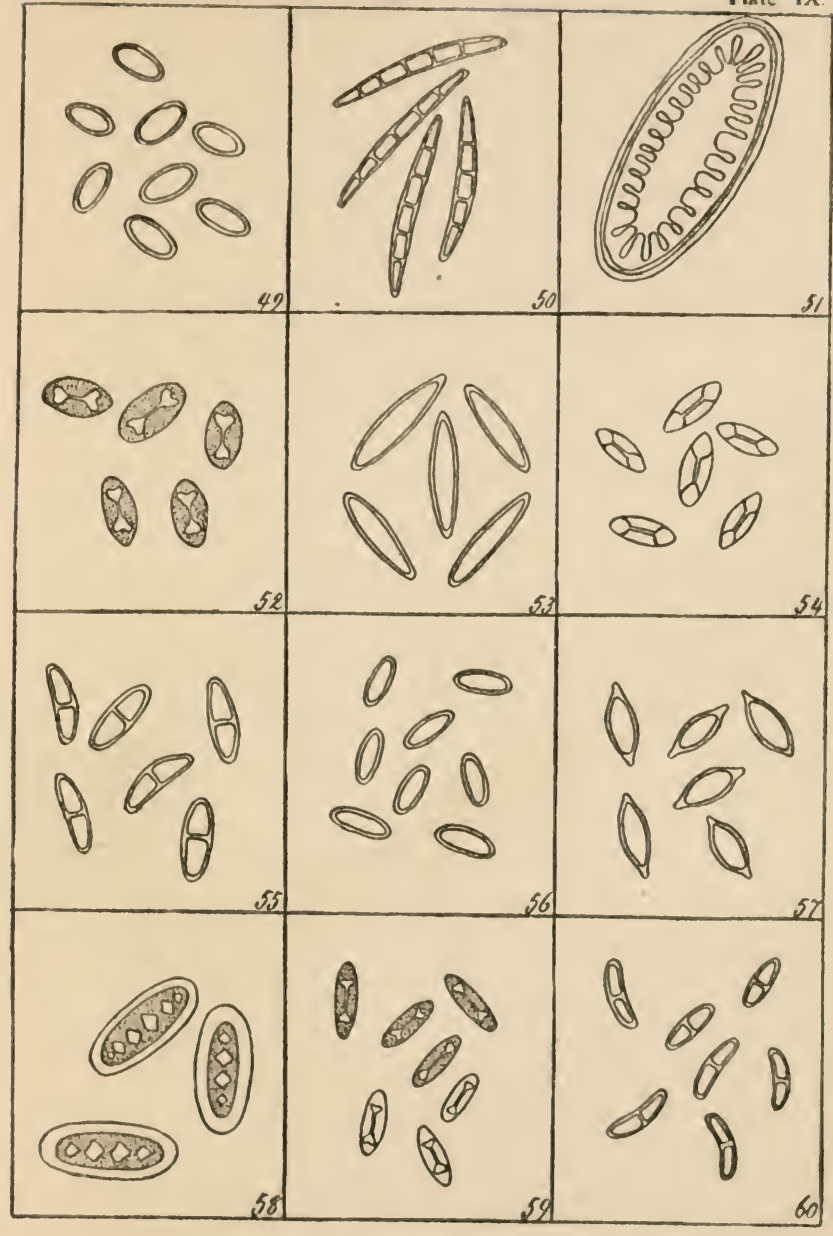

SPORES. 
PLATE $\mathrm{X}$.

Generic Spore-types (con.).

61. Rinodina.

62. Rocella.

63. Solorina.

64. Speerschneidera.

65. Sphærophorus.

66. Stereocaulon.

67. Sticta.

68. Stictina.

69. Theloschistes.

70. Thelotrema.

71. Trypethelium.

72. Umbilicaria. 


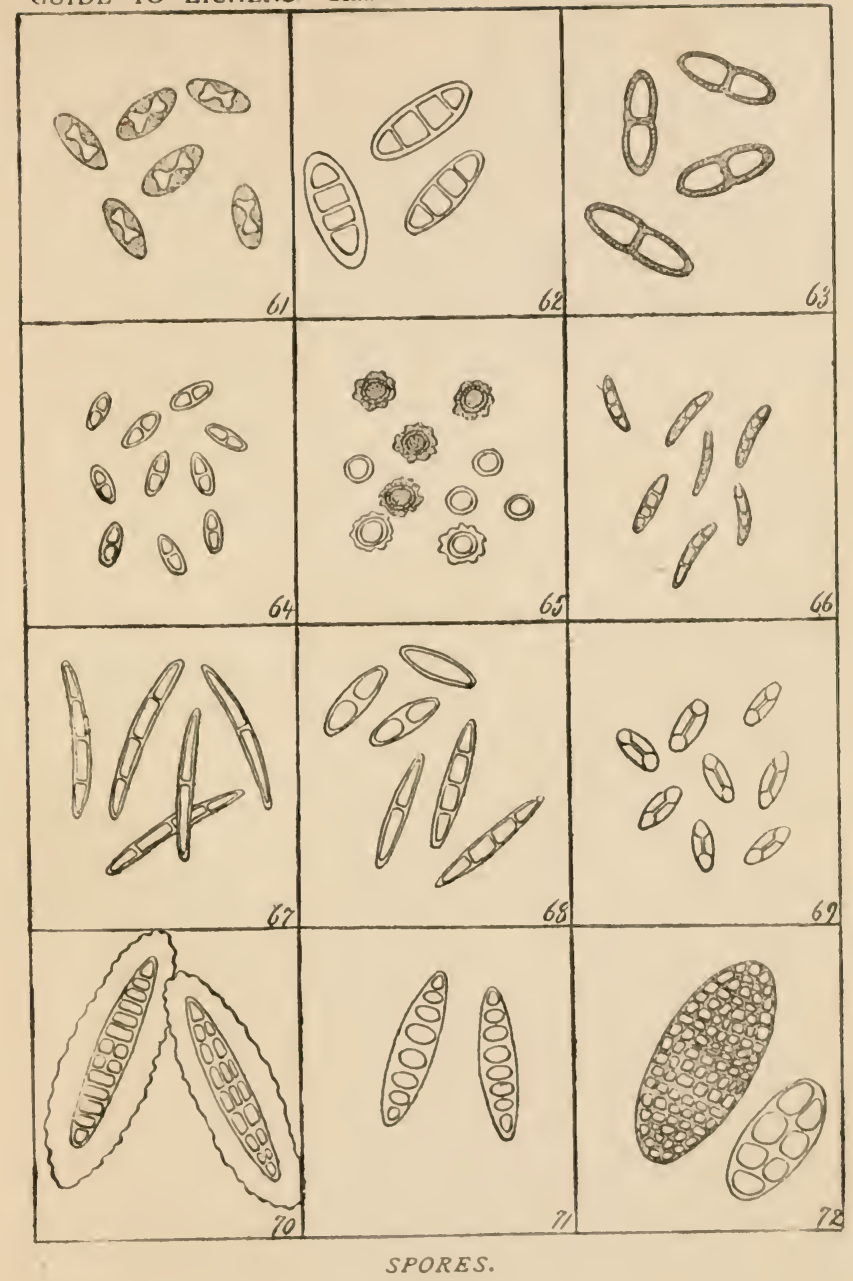


PLATE XI.

Generic Spore-types (con.).

73. Urceolaria.

74. Usnea.

75. Verrucaria.

76. Xylographa. 


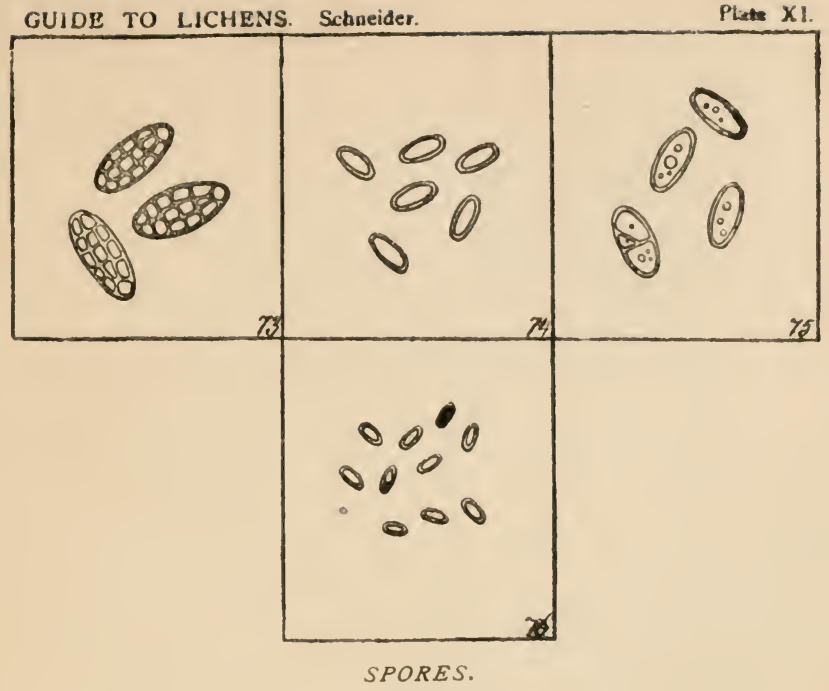






